Prepared in cooperation with the Rhode Island Department of Health

\title{
Areas Contributing Recharge to Production Wells and Effects of Climate Change on the Groundwater System in the Chipuxet River and Chickasheen Brook Basins, Rhode Island
}

Scientific Investigations Report 2014-5216 



\section{Areas Contributing Recharge to Production Wells and Effects of Climate Change on the Groundwater System in the Chipuxet River and Chickasheen Brook Basins, Rhode Island}

By Paul J. Friesz and Janet R. Stone

Prepared in cooperation with the Rhode Island Department of Health

Scientific Investigations Report 2014-5216 


\title{
U.S. Department of the Interior SALLY JEWELL, Secretary
}

\section{U.S. Geological Survey \\ Suzette M. Kimball, Acting Director}

\author{
U.S. Geological Survey, Reston, Virginia: 2014
}

For more information on the USGS - the Federal source for science about the Earth, its natural and living resources, natural hazards, and the environment, visit http://www.usgs.gov/ or call 1-888-ASK-USGS.

For an overview of USGS information products, including maps, imagery, and publications, visit http://www.usgs.gov/pubprod/.

To order this and other USGS information products, visit http://store.usgs.gov/.

Any use of trade, firm, or product names is for descriptive purposes only and does not imply endorsement by the U.S. Government.

Although this information product, for the most part, is in the public domain, it also may contain copyrighted materials as noted in the text. Permission to reproduce copyrighted items must be secured from the copyright owner.

Suggested citation:

Friesz, P.J., and Stone, J.R., 2014, Areas contributing recharge to production wells and effects of climate change on the groundwater system in the Chipuxet River and Chickasheen Brook Basins, Rhode Island: U.S. Geological Survey Scientific Investigations Report 2014-5216, 56 p., 1 pl., http://dx.doi.org/10.3133/sir20145216.

ISSN 2328-0328 (online) 


\section{Acknowledgments}

The authors especially thank Clayton Commons (Rhode Island Department of Health, Office of Drinking Water Quality), and Ernie Panciera (Rhode Island Department of Environmental Management, Office of Water Resources), for their support of the study and suggestions. The authors appreciate the assistance of Robert Bozikowski (Water System Manager, University of Rhode Island) and Henry Meyer (Manager, Kingston Water District) for information concerning groundwater withdrawals. The authors thank Tim McCobb (U.S. Geological Survey [USGS]) for writing computer programs to facilitate the climate change analysis in this report. Finally, the authors also thank Jeff Barbaro, Dave Bjerklie, William Burton, Anna Glover, John Masterson, Rodney Sheets, and Jennifer Stanton, all of the USGS, for their helpful reviews of the report. 



\section{Contents}

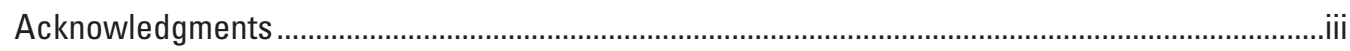

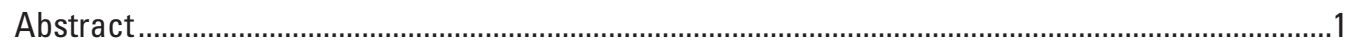

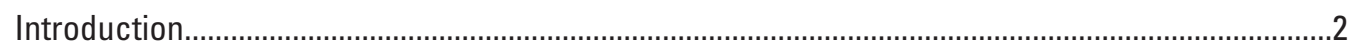

Purpose and Scope ....................................................................................................... 4

Description of Study Area and Previous Investigations ........................................................

Geology

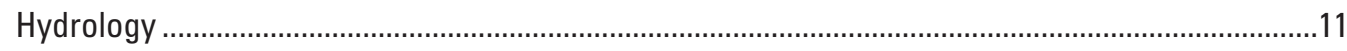

Development of Steady-State and Transient Numerical Models ..................................................12

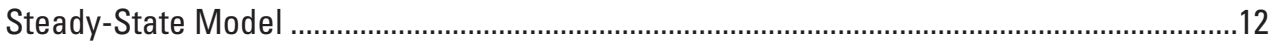

Model Extent and Spatial Discretization.........................................................................12

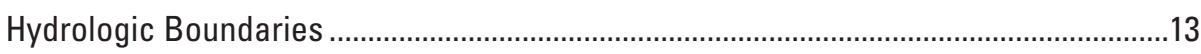

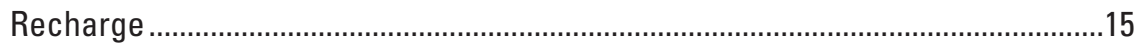

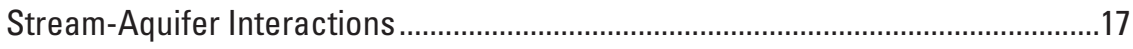

Water Withdrawals and Return Flow ...................................................................17

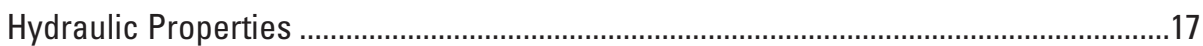

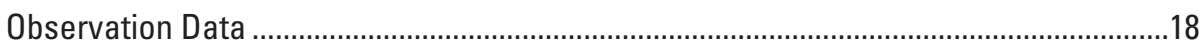

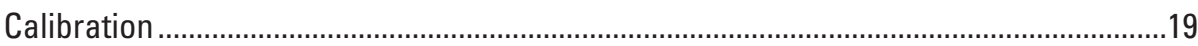

Estimation of Model Parameters.........................................................................19

Simulated Water Table and Water Budget.................................................................

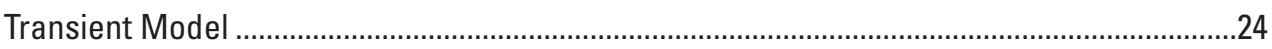

Time Discretization and Initial Conditions ...............................................................24

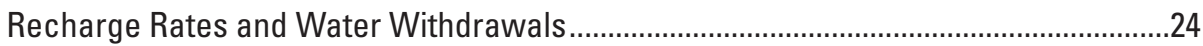

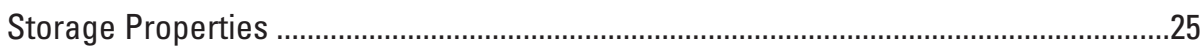

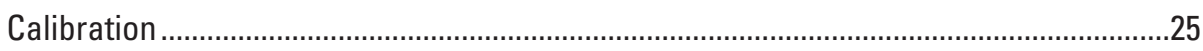

Simulation of Areas Contributing Recharge and Prediction Uncertainty Analysis ..........................27

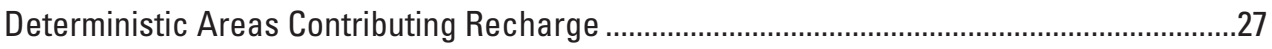

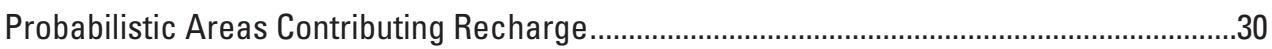

Effects of Climate Change on the Groundwater System ............................................................35

General Circulation Models and Emission Scenarios ...........................................................35

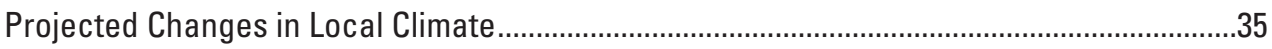

Projected Changes in Recharge, Actual Evapotranspiration, and Soil Moisture ....................38

Projected Changes in Groundwater Hydrology ......................................................................40

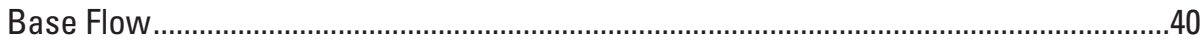

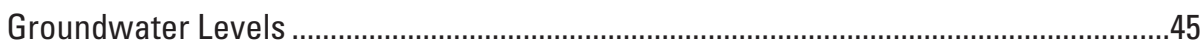

Areas Contributing Recharge .....................................................................................47

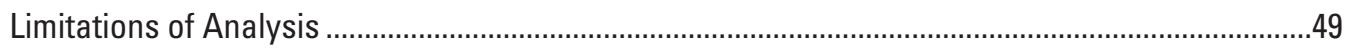

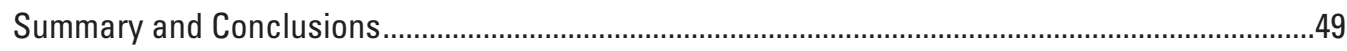

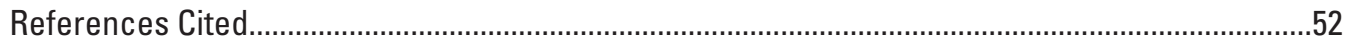




\section{Plate}

1. Surficial materials map of the Chipuxet River and Chickasheen Brook Basins, Rhode Island

\section{Figures}

1. Map showing generalized hydrogeology, production wells, selected U.S. Geological Survey long-term network streamgages and observation wells, and model extent in the Chipuxet River and Chickasheen Brook Basins, Rhode Island

2. Map showing land uses in the Chipuxet River and Chickasheen Brook Basins, Rhode Island.

3. Diagrams showing cross sections $A, A-A^{\prime}, B, B-B^{\prime}$, and $C, C-C^{\prime}$ in the Chipuxet River and Chickasheen Brook Basins, Rhode Island...

4. Map showing glacial lakes and retreatal ice-margin positions in the vicinity of the Chipuxet River and Chickasheen Brook Basins, Rhode Island

5. Map showing groundwater-level observations, streamgages with continuous and partial records, and model stream cells in the Chipuxet River and Chickasheen Brook Basins, Rhode Island

6. Map showing mean annual recharge from 1974 through 2003 in the Chipuxet River and Chickasheen Brook Basins, Rhode Island.

7. Graph showing composite scaled sensitivities for model parameters, Chipuxet River and Chickasheen Brook Basins, Rhode Island.

8. Graphs showing relation of $A$, weighted observation to weighted simulated equivalent and $B$, weighted residual to weighted simulated equivalent, Chipuxet River and Chickasheen Brook Basins, Rhode Island.

9. Map showing spatial distribution of weighted residuals and simulated water-table contours for calibrated, steady-state conditions in the Chipuxet River and Chickasheen Brook Basins, Rhode Island.

10. Graph showing normal probability of the weighted residuals, Chipuxet River and Chickasheen Brook Basins, Rhode Island

11. Graphs showing average monthly observed and simulated $A$, water-level altitudes at observation well SNW6 and $B$, base flow at the Chipuxet River streamgage in the Chipuxet River and Chickasheen Brook Basins, Rhode Island

12. Map showing simulated areas contributing recharge to the production wells at their average pumping rates from 2007 through 2011 in the Chipuxet River and Chickasheen Brook Basins, Rhode Island

13. Map showing simulated areas contributing recharge to the production wells at their maximum pumping rates in the Chipuxet River and Chickasheen Brook Basins, Rhode Island

14. Map showing simulated groundwater traveltimes to the production wells at their maximum pumping rates in the Chipuxet River and Chickasheen Brook Basins, Rhode Island.

15. Graphs showing model-parameter distributions $A$, before and $B$, after acceptance criteria were applied to determine the probabilistic areas contributing recharge to the well centers in the Chipuxet River and Chickasheen Brook Basins, Rhode Island 
16. Map showing simulated probabilistic areas contributing recharge to the well centers at their average pumping rates from 2007 through 2011 in the Chipuxet River and Chickasheen Brook Basins, Rhode Island.

17. Maps showing simulated probabilistic areas contributing recharge to $A$, the well center adjacent to the Chipuxet River and $B$, well KWD-3 adjacent to the Genesee Brook, at their maximum pumping rates in the Chipuxet River and Chickasheen Brook Basins, Rhode Island.

18. Graphs showing seasonal and annual projected changes in $A$, temperature and $B$, precipitation for three periods in the 21 st century (2010-39, 2040-69, and 2070-99) compared with those in the late 20th century (1970-99) for two greenhouse gas emission scenarios ( $\mathrm{B} 1$, lower emissions and $\mathrm{A} 2$, higher emissions) in the Chipuxet River and Chickasheen Brook Basins, Rhode Island.

19. Graphs showing $A$, calculated recharge for the late 20th century (1970-99) and the late 21st century (2070-99) for two greenhouse gas emission scenarios (B1, lower emissions and $A 2$, higher emissions) and changes in recharge for three periods in the 21st century (2010-39; 2040-69, and 2070-99) relative to the late 20th century (1970-99) for emission scenarios $B, \mathrm{~B} 1$ and $C, \mathrm{~A} 2$ in the Chipuxet River and Chickasheen Brook Basins, Rhode Island.

20. Graphs showing $A$, calculated actual evapotranspiration for the late 20th century (1970-99) and the late 21st century (2070-99) for two greenhouse gas emission scenarios ( $\mathrm{B} 1$, lower emissions and $\mathrm{A} 2$, higher emissions) and changes in actual evapotranspiration for three periods in the 21st century (2010-39; 2040-69, and 2070-99) relative to the late 20th century (1970-99) for emission scenarios $B, B 1$ and $C, A 2$ in the Chipuxet River and Chickasheen Brook Basins, Rhode Island.

21. Graphs showing $A$, calculated soil moisture for the late 20th century (1970-99) and the late 21st century (2070-99) for two greenhouse gas emission scenarios ( $B 1$, lower emissions and $A 2$, higher emissions) and changes in soil moisture for three periods in the 21st century (2010-39; 2040-69, and 2070-99) relative to the late 20th century (1970-99) for emission scenarios $B, B 1$ and $C, A 2$ in the Chipuxet River and Chickasheen Brook Basins, Rhode Island.

22. Graphs showing $A$, simulated base flow to the Chipuxet River for the late 20th century (1970-99) and the late 21st century (2070-99) for two greenhouse gas emission scenarios ( $\mathrm{B} 1$, lower emissions and $\mathrm{A} 2$, higher emissions) and changes in base flow for three periods in the 21st century (2010-39; 2040-69, and 2070-99) relative to the late 20th century (1970-99) for emission scenarios $B, B 1$ and $C, A 2$ in the Chipuxet River and Chickasheen Brook Basins, Rhode Island.

23. Graphs showing $A$, simulated base flow to a tributary of the Chipuxet River for the late 20th century (1970-99) and the late 21st century (2070-99) for two greenhouse gas emission scenarios ( $\mathrm{B} 1$, lower emissions and $\mathrm{A} 2$, higher emissions) and changes in base flow for three periods in the 21st century (2010-39; 2040-69, and 2070-99) relative to the late 20th century (1970-99) for emission scenarios $B, \mathrm{~B} 1$ and $C, A 2$ in the Chipuxet River and Chickasheen Brook Basins, Rhode Island

24. Graph showing simulated water-level altitudes at observation well SNW6 for the late 20th century (1970-99) and late 21st century (2070-99) for two greenhouse gas emission scenarios ( $\mathrm{B} 1$, lower emissions and $\mathrm{A} 2$, higher emissions) in the Chipuxet River and Chickasheen Brook Basins, Rhode Island.....

25. Maps showing decreases in simulated water-table altitudes between the late 20th century (1970-99) and the late 21st century (2070-99) for $A$, September and $B, 0$ ctober for two greenhouse gas emission scenarios (B1, lower emissions and A2, higher emissions) in the Chipuxet River and Chickasheen Brook Basins, Rhode Island 


\section{Tables}

1. Characteristics of the production wells in the Chipuxet River and Chickasheen Brook Basins, Rhode Island.

2. Definition of model parameters and statistics on parameter values, whether estimated or specified, Chipuxet River and Chickasheen Brook Basins, Rhode Island

3. General circulation models used in the climate change analysis in the Chipuxet River and Chickasheen Brook Basins, Rhode Island.

\section{Conversion Factors}

\begin{tabular}{lll}
\hline \multicolumn{1}{c}{ Multiply } & By & \multicolumn{1}{c}{ To obtain } \\
\hline inch (in.) & Length & \\
foot (ft) & 2.54 & centimeter $(\mathrm{cm})$ \\
mile (mi) & 0.3048 & meter $(\mathrm{m})$ \\
\hline & 1.609 & kilometer $(\mathrm{km})$ \\
\hline square mile $\left(\mathrm{mi}^{2}\right)$ & Area & \\
\hline & 2.590 & square kilometer $\left(\mathrm{km}^{2}\right)$ \\
\hline cubic foot per second $\left(\mathrm{ft}{ }^{3} / \mathrm{s}\right)$ & Flow rate & \\
gallon per minute $\left(\mathrm{gal} / \mathrm{min}^{2}\right)$ & 0.02832 & cubic meter per $\mathrm{second}\left(\mathrm{m}^{3} / \mathrm{s}\right)$ \\
inch per year $(\mathrm{in} / \mathrm{yr})$ & 0.06309 & liter per second $(\mathrm{L} / \mathrm{s})$ \\
& 25.4 & millimeter per year $(\mathrm{mm} / \mathrm{yr})$ \\
\hline foot per day $(\mathrm{ft} / \mathrm{d})$ & Hydraulic conductivity & \\
\hline
\end{tabular}

Temperature in degrees Fahrenheit $\left({ }^{\circ} \mathrm{F}\right)$ may be converted to degrees Celsius $\left({ }^{\circ} \mathrm{C}\right)$ as follows: ${ }^{\circ} \mathrm{C}=\left({ }^{\circ} \mathrm{F}-32\right) / 1.8$

\section{Datums}

Vertical coordinate information is referenced to the National Geodetic Vertical Datum of 1929 (NGVD 29).

Horizontal coordinate information is referenced to the North American Datum of 1983 (NAD 83). Altitude, as used in this report, refers to distance above the vertical datum. 


\title{
Abbreviations
}

\author{
GCMs general circulation models \\ KWD Kingston Water District \\ lidar light detection and ranging \\ RIDEM Rhode Island Department of Environmental Management \\ RIDOH Rhode Island Department of Health \\ USGS U.S. Geological Survey \\ URI University of Rhode Island
}





\title{
Areas Contributing Recharge to Production Wells and Effects of Climate Change on the Groundwater System in the Chipuxet and Chickasheen River Basins, Rhode Island
}

\author{
By Paul J. Friesz and Janet R. Stone
}

\section{Abstract}

The Chipuxet River and Chickasheen Brook Basins in southern Rhode Island are an important water resource for public and domestic supply, irrigation, recreation, and aquatic habitat. The U.S. Geological Survey, in cooperation with the Rhode Island Department of Health, began a study in 2012 as part of an effort to protect the source of water to six largecapacity production wells that supply drinking water and to increase understanding of how climate change might affect the water resources in the basins. Soil-water-balance and groundwater-flow models were developed to delineate the areas contributing recharge to the wells and to quantify the hydrologic response to climate change. Surficial deposits of glacial origin ranging from a few feet to more than 200 feet thick overlie bedrock in the 24.4-square mile study area. These deposits comprise a complex and productive aquifer system.

Simulated areas contributing recharge to the production wells covered a total area of 0.63 square miles for average well withdrawal rates from 2007 through 2011 (total rate of 583 gallons per minute). Simulated areas contributing recharge for the maximum well pumping capacities (total rate of 3,700 gallons per minute) covered a total area of 2.55 square miles. Most simulated areas contributing recharge extend upgradient of the wells to morainal and upland till deposits and to groundwater divides. Some simulated areas contributing recharge include small, isolated areas remote from the wells. Relatively short groundwater traveltimes from recharging locations to discharging wells indicated that the wells are vulnerable to contamination from land-surface activities; median traveltimes ranged from 3.5 to 8.6 years for the production wells examined, and 57 to 91 percent of the traveltimes were 10 years or less. Land cover in the areas contributing recharge includes a substantial amount of urban and agriculture land use for five wells adjacent to the Chipuxet River; for one well adjacent to a tributary stream, land use is less developed.

The calibrated groundwater-flow model provided a single, best representation of the areas contributing recharge to a production well. The parameter variance-covariance matrix from model calibration was used to create parameter sets that reflect the uncertainty of the parameter estimates and the correlation among parameters to evaluate the uncertainty associated with the predicted contributing areas to the wells. A Monte Carlo analysis led to contributing areas expressed as a probability distribution that differed from a single deterministic contributing area. Because of the effects of parameter uncertainty, the size of the probabilistic contributing areas for both average and maximum pumping rates was larger than the size of the deterministic contributing areas for the wells. Thus, some areas not in the deterministic contributing area might actually be in the contributing area, including additional areas of urban and agricultural land use that has the potential to contaminate groundwater. Additional areas that might be in the contributing area included recharge originating near the pumping wells that have relatively short groundwater-flow paths and traveltimes. At the maximum pumping rates, areas associated with low probabilities extended long distances along groundwater divides in the uplands remote from the wells.

Climate projections for the Chipuxet River and Chickasheen Brook Basins from downscaled output from general circulation models indicate that mean annual temperature might increase by 4.7 degrees Fahrenheit and 8.0 degrees Fahrenheit by the late 21 st century (2070-99) compared with the late 20th century (1970-99) under scenarios of lower and higher emissions of greenhouse gases, respectively. By the late $21 \mathrm{st}$ century, winter and spring precipitation is projected to increase by 12 to 17 percent, summer precipitation to increase by about the same as mean annual precipitation ( 8 percent), and fall precipitation to decrease by 5 percent for both emission scenarios compared with the late 20th century. Soil-water-balance simulations indicate that, although precipitation is expected to increase in three seasons, only in winter do precipitation increases exceed actual evapotranspiration increases. Recharge is projected to decrease in fall and generally change little in spring and summer. By the late 21st century, winter recharge is expected to increase by 13 percent for the lower emissions scenario and by 15 percent for the higher emissions scenario. In fall, recharge is projected to diminish by 13 percent for the lower emissions scenario and by 24 percent for the higher emissions scenario. Although recharge is projected to change seasonally in the 21 st century, mean annual recharge changes 
minimally. Soil moisture is projected to decrease in the 21 st century from spring through fall because of increases in potential evapotranspiration, and in fall because of decreases in precipitation in addition to increases in potential evapotranspiration. By the late 21 st century, soil moisture for the lower emissions scenario is expected to decrease by 11 percent in summer and 15 percent in fall, and for the higher emissions scenario, decrease by 23 percent for both seasons. These decreases in soil moisture during the growing season might have implications for agriculture in the study area.

Predicted changes in the magnitude and seasonal distribution of recharge in the 21 st century increase simulated base flows and groundwater levels in the winter months for both emission scenarios, but because of less recharge in the fall and less or about the same recharge in the preceding months of spring and summer, base flows and groundwater levels in the fall months decrease for both emission scenarios. October has the largest base flow and groundwater level decreases. By the late 21st century, base flows at the Chipuxet River in October are projected to decrease by 9 percent for the lower emissions scenario and 18 percent for the higher emissions scenario. For a headwater stream in the upland till with shorter groundwater-flow paths and lower storage properties in its drainage area, base flows in October are projected to diminish by 28 percent and 42 percent for the lower and higher emissions scenarios by the late 21 st century. Groundwater level changes in the uplands show substantial decreases in fall, but because of the large storage capacity of stratified deposits, water levels change minimally in the valley. By the late 21st century, water levels in large areas of upland till deposits in October are projected to decrease by up to 2 feet for the lower emissions scenario, whereas large areas decrease by up to 5 feet, with small areas with decreases of as much as 10 feet, for the higher emissions scenario. For both emission scenarios, additional areas of till go dry in fall compared with the late 20th century. Thus projected changes in recharge in the 21 st century might extend low flows and low water levels for the year later in fall and there might be more intermittent headwater streams compared with the late 20th century with corresponding implications to aquatic habitat. Finally, the size and location of the simulated areas contributing recharge to the production wells are minimally affected by climate change because mean annual recharge, which is used to determine the contributing areas to the production wells, is projected to change little in the 21 st century.

\section{Introduction}

The Chipuxet River and Chickasheen Brook Basins in southern Rhode Island (fig. 1) are an important water resource for public and domestic supply, irrigation, recreation, and aquatic habitat. Large-capacity production wells supply village centers and a university campus. Irrigated lands include agriculture, primarily turf farming. Worden Pond and Great
Swamp, one of the largest wetlands in New England, are important recreational and wildlife management areas. To maintain the high-quality water in the basins through the 21 st century, water-resource planners need information on the source of water to large-capacity production wells and how changes in climate might affect the water resources.

One of the missions of the Rhode Island Department of Health (RIDOH), Office of Drinking Water Quality, is to assess the susceptibility and risk of public-water supplies to contamination and to encourage land-use planning within the areas contributing recharge to a production well. The Rhode Island Department of Environmental Management (RIDEM), Office of Water Resources, has determined contributing areas to most production wells in Rhode Island, but RIDEM and RIDOH want to more accurately delineate contributing areas to wells in hydrogeologically complex settings such as the Chipuxet River and Chickasheen Brook Basins. Numerical groundwater-flow modeling coupled with a particle tracking technique is a more advanced method for delineating contributing areas than the analytical methods that have previously been used for this purpose. In addition, without an evaluation of the uncertainty associated with the predicted contributing area to a well, the source area might be underestimated, thereby leaving the well inadequately protected.

The water systems of the Kingston Water District (KWD) and the University of Rhode Island (URI) each consist of three large-capacity production wells from which drinking water is withdrawn (fig. 1). The KWD and URI production wells supply a total average rate of 0.9 million gallons per day (Mgal/d) from an unconfined aquifer of glacial origin. Land uses in the vicinity of these wells include the URI campus and agricultural, residential, and commercial uses in the village centers of Kingston and West Kingston. Development and population growth are expected to increase in the future in the surrounding area. Nitrate concentrations are slightly elevated in some of these wells, indicating the presence of fertilizers or wastewater (Clayton Commons, Rhode Island Department of Health, written commun., 2011). In addition, because the herbicide Dacthal (a trademarked version of dimethyl tetrachloroterephthalate [DCPA]), an unregulated contaminant, has been detected in one of the KWD wells, KWD has temporarily removed this well from service since 2012 (Kingston Water District, 2013). These water-quality issues have raised concerns over the quality of groundwater in this area and the need to better understand the source of water to the KWD and URI wells.

Changes in climate from increasing atmospheric concentrations of greenhouse gases from human development have raised temperatures in the northeastern United States by 0.45 degrees Fahrenheit $\left({ }^{\circ} \mathrm{F}\right)$ per decade since 1970 (Hayhoe and others, 2007). Numerous studies in New England have documented hydrologic changes resulting from rising temperatures and changing precipitation patterns, such as decreasing snow accumulation in winter, earlier snowmelt runoff, and increases in groundwater levels (Huntington and others, 2004; Hodgkins and Dudley, 2006; Bjerklie and others, 2011; 


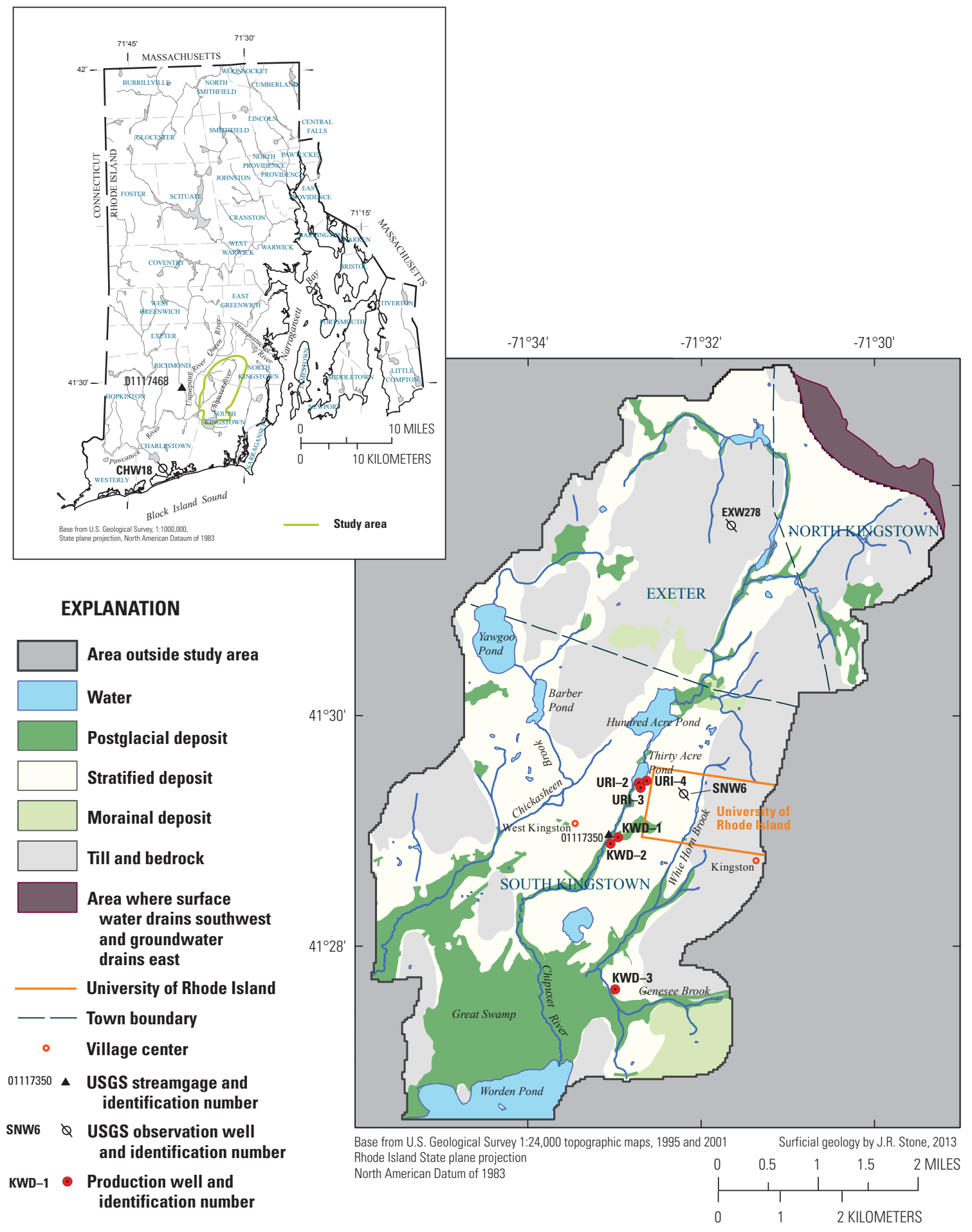

Figure 1. Generalized hydrogeology, production wells, selected U.S. Geological Survey (USGS) long-term network streamgages and observation wells, and model extent in the Chipuxet River and Chickasheen Brook Basins, Rhode Island. Production wells are listed in table 1. 
Areas Contributing Recharge to Production Wells and Impacts of Climate Change, Chipuxet and Chickasheen Basins

Dudley and Hodgkins, 2013). Temperatures in the northeastern United States are expected to continue to rise. Climate projections for the northeastern United States from downscaled output from general circulation models (GCMs) that simulate atmospheric and oceanic interactions indicate that the mean annual temperature might increase by 5 to $8^{\circ} \mathrm{F}$ and the mean annual precipitation might increase by 7 to 9 percent by the late 21 st century, depending on the emission scenario (Hayhoe and others, 2007). Projected temperature and precipitation changes through the 21st century have the potential to affect the timing and magnitude of groundwater recharge, which in turn might affect the groundwater system, such as base flow, groundwater levels, and the contributing areas to the production wells. Water-resource planners are concerned about these potential effects on the groundwater resources of the Chipuxet River and Chickasheen Brook Basins and need a quantitative assessment of climate effects for long-term planning to adapt to these changes.

The USGS, in cooperation with the RIDOH, began a 2-year study in 2012 as part of an effort to protect the source of water to the six large-capacity production wells and to increase understanding of how climate change might affect the groundwater system in the Chipuxet River and Chickasheen Brook Basins. A characterization of the hydrogeologic framework of the glacial sediments provided the information to develop numerical groundwater-flow models of the study area. The groundwater-flow models were used to delineate the areas contributing recharge to the production wells, provide an uncertainty analysis of these predicted contributing areas, and quantify the response of the groundwater system to climate change.

Downscaled climate projections from GCMs have been used in surface-water modeling studies in New England to determine the effects on surface-water hydrology (Hayhoe and others, 2007; Bjerklie and others, 2012; Dudley and others, 2012; Tetra Tech, Inc., 2012). Mack (2009) used projected seasonal changes in temperature and precipitation that were spatially averaged over the northeastern United States by Hayhoe and others (2007) to estimate changes in recharge for a groundwater-flow model to determine the effects on groundwater resources in a New Hampshire basin. For the present study, downscaled climate projections specific to the Chipuxet River and Chickasheen Brook Basins were used to quantify effects of climate change on groundwater recharge and the groundwater system. Results of the climate change analysis might be applicable to aquifers of glacial origin in the northeastern United States where there is little snow accumulation during the winter.

\section{Purpose and Scope}

This report describes the hydrogeology of the Chipuxet River and Chickasheen Brook Basins and documents the design and calibration of numerical groundwater-flow models for the purpose of delineating the areas contributing recharge to six production wells supplying drinking water and quantifying the response of the groundwater system to climate change. A soil water balance was used to calculate spatially distributed recharge for the groundwater-flow models. KWD and URI each operate three production wells in the 24.4 square miles $\left(\mathrm{mi}^{2}\right)$ of study area. The calibrated model provides a single, best representation of the contributing area to each production well. Summary statistics from the calibrated model were used to evaluate the uncertainty associated with the predicted contributing area to a well. This analysis led to a contributing area expressed as a probability distribution.

Climate projections from five GCMs and two emission scenarios were used in the climate change analysis. The two emission scenarios represent a lower and higher emissions of greenhouse gases. The effects of climate change on water-balance components near the land surface, including groundwater recharge, and on the groundwater system, including base flows, groundwater levels, and contributing areas to production wells, were investigated by comparing three 30 -year periods in the 21 st century to an historical 30 -year baseline period in the late 20th century.

\section{Description of Study Area and Previous Investigations}

The Chipuxet River and Chickasheen Brook Basins are in southern Rhode Island and include parts of the towns of South Kingstown, North Kingstown, and Exeter (fig. 1). These two streams along with the Usquepaug and Queen Rivers form the headwaters of the Pawcatuck River, which discharges to Block Island Sound on the coast of Rhode Island. The northeastern part of the Chipuxet River Basin is not within the study area because previous studies (Allen and others, 1966; Dickerman and Barlow, 1997) have shown that groundwater and surfacewater divides do not coincide between the Chipuxet River Basin and the Annaquatucket River Basin. Groundwater in this part of the Chipuxet River Basin flows east of the study area to streams that eventually discharge to Narragansett Bay. The total size of the study area is $24.4 \mathrm{mi}^{2}$.

The study area is part of the Seaboard Lowland section of the New England physiographic province (Fenneman, 1938). The landscape is characterized by gently rolling uplands and relatively narrow, flat valleys that trend northeast to southwest. Land-surface altitudes range from about 90 feet (ft) in the valleys along the shoreline of Worden Pond and along the downstream end of Chickasheen Brook to $320 \mathrm{ft}$ in the uplands dividing Chipuxet River Basin from the Chickasheen Brook Basin.

Surficial deposits of glacial and postglacial origin overlie bedrock in the valleys and uplands. Most groundwater withdrawals in the study area are by large-capacity production wells (fig. 1; table 1) that supply potable water; these production wells are screened in transmissive glacial deposits composed of sand and gravel or sand. The water systems of the KWD and URI are each composed of three production 
Table 1. Characteristics of the production wells in the Chipuxet River and Chickasheen Brook Basins, Rhode Island.

[Altitudes in feet relative to the National Geodetic Vertical Datum of 1929. USGS, U.S. Geological Survey; ft, feet; in., inches; gal/min, gallons per minute; $\mathrm{ft}^{3} / \mathrm{s}$, cubic feet per second]

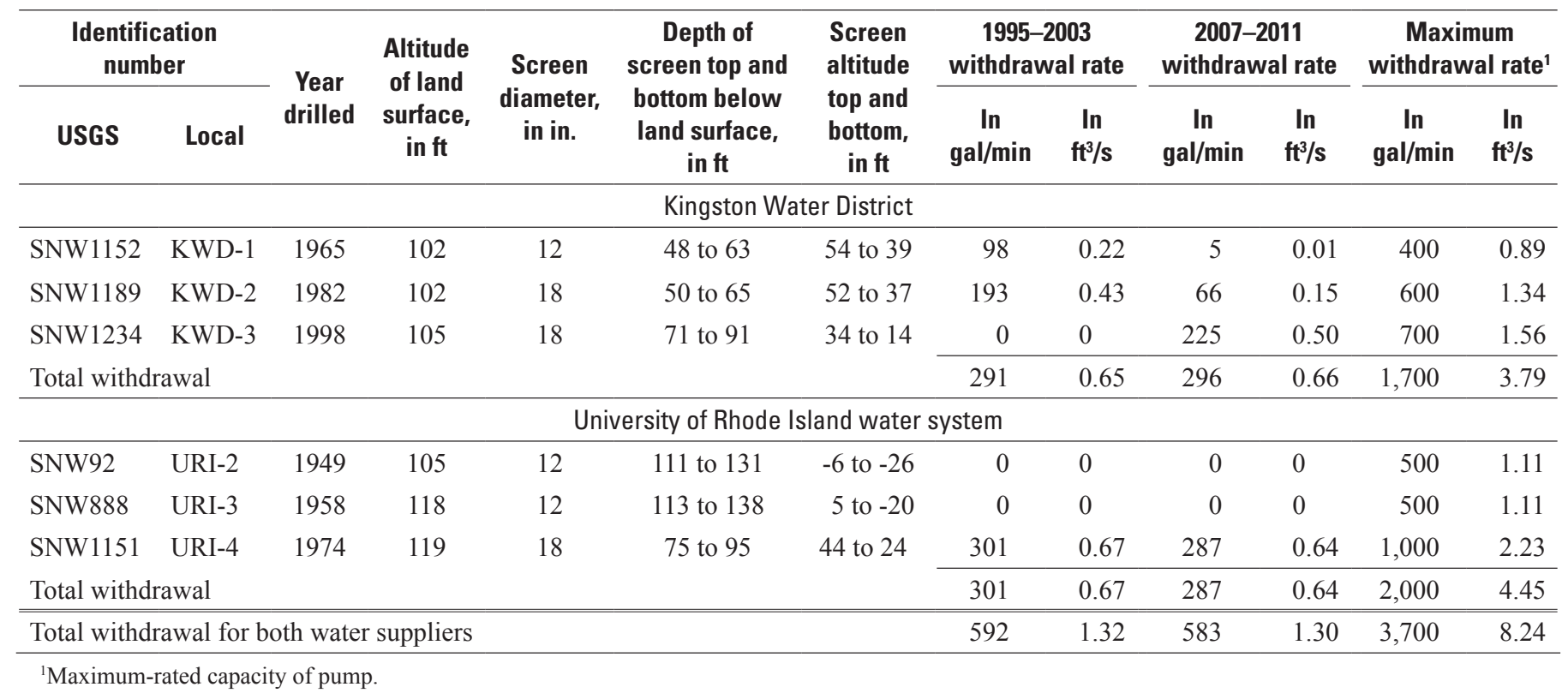

wells. The URI production wells (URI-2, URI-3, and URI-4) and two of the KWD production wells (KWD-1 and KWD-2) are adjacent to the Chipuxet River in the central part of the basin. The most recently installed production well (KWD-3) began withdrawals in 2004 and is adjacent to Genesee Brook, a tributary to the Chipuxet River.

Land use in the study area is primarily forested but also includes a substantial amount of urban and agricultural uses (fig. 2). Urban land uses include institutional (URI campus), residential, commercial, and industrial. Agriculture land use includes irrigated cropland, primarily turf farms. Wetlands are mainly forested.

One measure that the RIDOH uses for assessing well vulnerability to contamination is the amount of urban and agricultural land in the contributing area to a well. Urban and agricultural land uses store, apply, or generate pollutants that have the potential to contaminate nearby water resources (Joubert and others, 2003). The distribution of urban and agricultural land uses (fig. 2) is important in assessing the potential sources of contaminants near the well. The five production wells adjacent to the Chipuxet River are in an area with substantial amount of urban and agriculture land cover, whereas well KWD-3 near Genesee Brook is in a less developed part of the study area.

Previous investigations by the USGS have analyzed the geology and hydrology of part or all of the study area. Surficial and bedrock geology have been mapped by Power (1957, 1959), Kaye (1960), Schafer (1961), Moore (1964), and Hermes and others (1994). Reconnaissance studies of groundwater conditions, including measurements of groundwater levels in the valleys and in uplands, were done by Bierschenk (1956) and Hahn (1959). A comprehensive study of the availability of groundwater in the upper Pawcatuck River Basin, which includes the Chipuxet River and Chickasheen Brook Basins, was done by Allen and others (1966). An associated data report (Allen and others, 1963) compiled hydrologic and geologic data from this and the earlier groundwater studies. Two investigations in the 1980s (Dickerman, 1984; Johnston and Dickerman, 1985) focused on the groundwater resources of the central part of the Chipuxet River and Chickasheen Brook Basins where the earlier study (Allen and others, 1966) indicated the most transmissive deposits within the basins. This is the location of most of the production wells. These two studies focused on the hydraulic properties and water quality of the aquifer and development of these groundwater resources. An associated data report (Dickerman, 1976) compiled geohydrologic data that were used in these two studies. DeSimone and Ostiguy (1999) compiled hydrogeologic, water-quality, and land-use data to assess the vulnerability of production wells throughout the State to contamination. Water use information was compiled from 1995 through 1999 by Wild and Nimiroski (2004) for the Pawcatuck River Basin. More recently, Bent and others (2011) developed groundwater and surface-water models to evaluate the effects of water withdrawals and land-use changes on groundwater levels and streamflow in the Pawcatuck River Basin. One of the regional groundwater models done for this study (Masterson, 2011) included the upper Pawcatuck River Basin. 


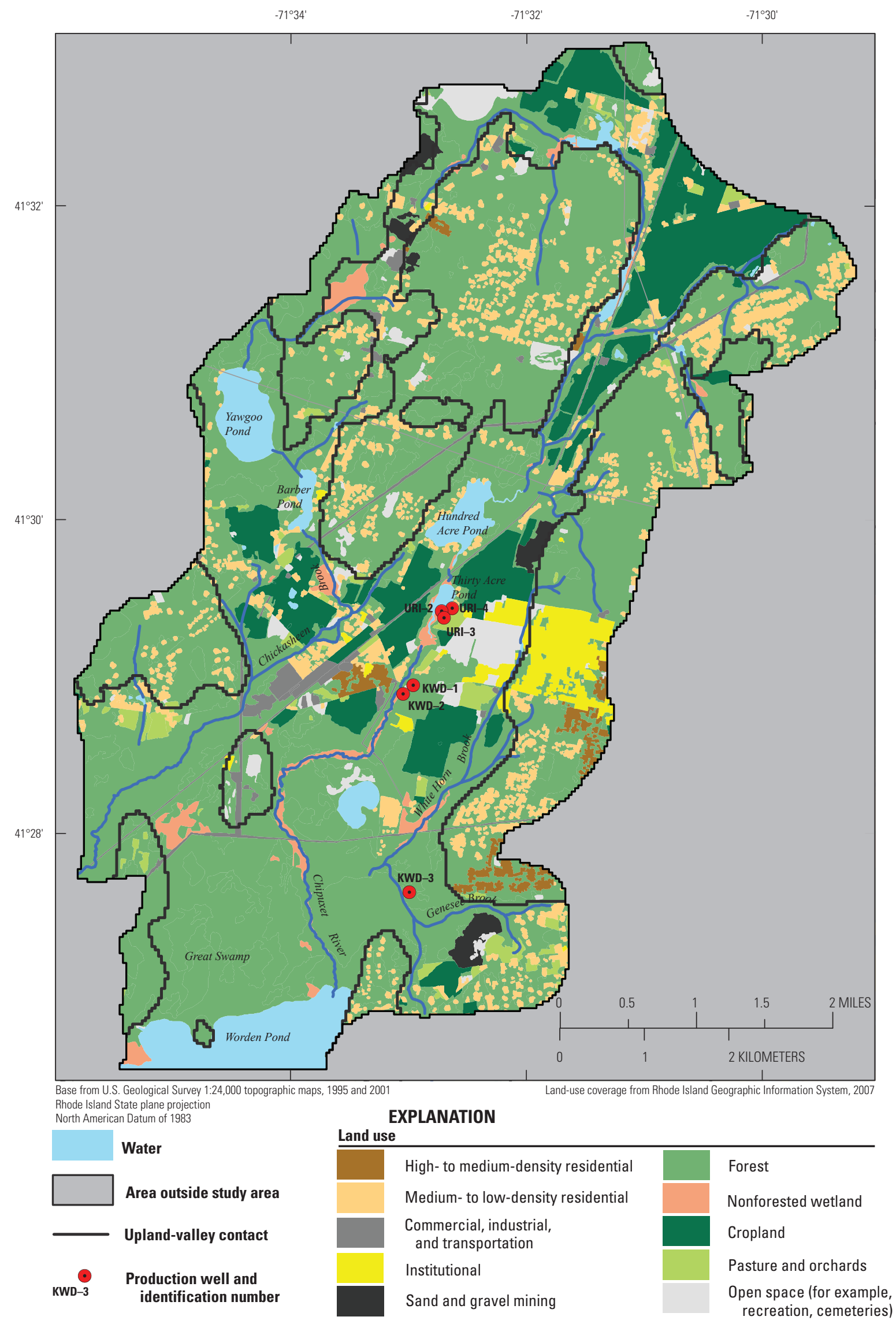

Figure 2. Land uses in the Chipuxet River and Chickasheen Brook Basins, Rhode Island. 


\section{Geology}

Three principal geologic units underlie the Chipuxet River and Chickasheen Brook Basins - glacial stratified deposits, glacial till, and crystalline bedrock; these geologic units have significantly different hydraulic characteristics. Crystalline bedrock is consolidated lithified rock with extremely low primary porosity. Groundwater flows along local, secondary fractures and joints in the bedrock. Till and stratified deposits are unconsolidated glacial sediments that overlie bedrock. Glacial stratified deposits comprise the productive aquifers in the region. Stratified deposits are further subdivided on the basis of texture into coarse-grained units (sand and gravel and sand) and fine-grained units (very fine sand, silt, and clay). Postglacial floodplain alluvium and wetland deposits locally overlie glacial deposits. A surficial geologic materials map and geologic cross sections showing textural units in the stratified deposits in the study area are shown on plate 1 and in figure 3 .

Bedrock controls the general topography in the region. The study area is underlain by metamorphosed intrusive igneous bedrock (augen granite gneiss of the Esmond Igneous Suite) of Neoproterozoic age as mapped by Hermes and others (1994). Most bedrock hills to the east and west of the Chipuxet River valley trend north-northeast due to the trend of the primary metamorphic foliation in the bedrock. The position of the bedrock valley occupied by the Chipuxet River is due to structural and (or) lithologic weakness in the bedrock, and this valley continues and deepens southward out of the study area. The present day diversion of the Chipuxet River westerly toward the Pawcatuck River is a glacial drainage diversion caused by deposition of the Charlestown recessional moraine and associated meltwater deposits across a formerly south-flowing river valley. Granitic bedrock in New England has extremely low primary porosity, and groundwater is present only in fractures that cut the rock mass.

Areas where bedrock lies at or near the land surface in the study area are shown in red (solid and ruled pattern) on the map on plate 1 ; the configuration of the bedrock surface beneath the surficial materials is indicated by the red contour lines. Bedrock-surface contours were constructed using reported depths to bedrock or refusal at all available wells and test holes and geologic inference based on a regional understanding of the thickness and distribution of surficial deposits. Depth to bedrock ranges from 0 to as much as $250 \mathrm{ft}$ in the study area. The deepest part of the bedrock valley beneath the present day Chipuxet River lies more than $125 \mathrm{ft}$ below sea level and deepens seaward where it continues beneath Worden Pond and the Charlestown moraine to the south (fig. 4; pl. 1).

Glacial deposits overlie bedrock in the study area and range from a few feet to more than $200 \mathrm{ft}$ in thickness (pl. 1). Most of these materials are deposits of the last two continental ice sheets that covered New England during the middle and late Pleistocene. Most were laid down during the advance and retreat of the last (late Wisconsinan) ice sheet, which reached its terminus on Long Island, New York, about 25,000 years ago and was retreating northward through the Chipuxet River and Chickasheen Brook Basins by about 21,000 years ago (Boothroyd and others, 1998; Balco and others, 2009). The glacial deposits are divided into two broad categories - glacial till and glacial meltwater deposits. Till was deposited directly by glacier ice and is characterized as a nonsorted matrix of sand, silt, and clay with variable amounts of pebbles, cobbles, and large boulders. Glacial meltwater deposits were laid down by meltwater in lakes and streams in front of the retreating ice margin during deglaciation. These materials, also referred to as glacial stratified deposits, consist of well- to poorly sorted layers of gravel, sand, silt, and clay. Postglacial sediments, primarily floodplain alluvium and wetland deposits, are thin surface units and make up a smaller part of the surficial materials in the study area.

The distribution of surficial materials that lie between the land surface and the bedrock surface is shown on the map on plate 1 . The surficial materials map is based on geologic units in the Kingston (Kaye, 1960), Slocum (Power, 1957), and Wickford (Schafer, 1961) quadrangles. The stacked unit delineation of textures within the glacial meltwater deposits was mapped using all available well and test hole logs and depositional models that allow prediction of the distribution of textures within glacial sediments. Cross-sections $A-A^{\prime}, B-B^{\prime}$, and $C-C^{\prime}$ (fig. 3) illustrate the characteristic vertical succession of glacial till, glacial meltwater deposits, and postglacial deposits. In upland areas, till is the major surficial material; it is present as a discontinuous blanket deposit of variable thickness over the bedrock surface. In most places, till is less than 10 to $15 \mathrm{ft}$ thick; areas where till is thicker than 10 to $15 \mathrm{ft}$ are indicated on the map on plate 1 by a darker green color. Till is thickest in drumlins, such as Huckleberry Hill and Sherman Hill, and on the northwestern sides of bedrock hills, such as the southern part of Great Neck. In the valleys, glacial meltwater deposits are the predominant surficial materials. These deposits generally overlie till; however, well logs indicate that in some places till is not present in the subsurface and the meltwater deposits lie directly on bedrock. Meltwater deposits in the deepest parts of the Chipuxet River valley are generally 100 to $200 \mathrm{ft}$ thick and completely cover the till-draped bedrock surface. Postglacial materials locally overlie the glacial deposits; alluvium underlies the Chipuxet River and Chickasheen Brook floodplains, and wetland deposits cover many floodplain surfaces and fill other poorly drained areas like kettle holes, where blocks of glacial ice that were buried by meltwater sediments subsequently melted.

Glacial till is generally a compact, nonsorted mixture of sand, silt, clay, and stones laid down directly by glacial ice. Tills laid down during two separate episodes of continental glaciation are present throughout southern New England (Stone and Borns, 1986; Melvin and others, 1992; Stone and others, 2005), and both types of till are present in the study area. The lower (Illinoian-age) till is discontinuous and is present only in areas of thick till (pl. 1, unit tt), which include drumlins (Huckleberry Hill and Sherman Hill) and the northwestern sides of bedrock hills (like Great Neck). 

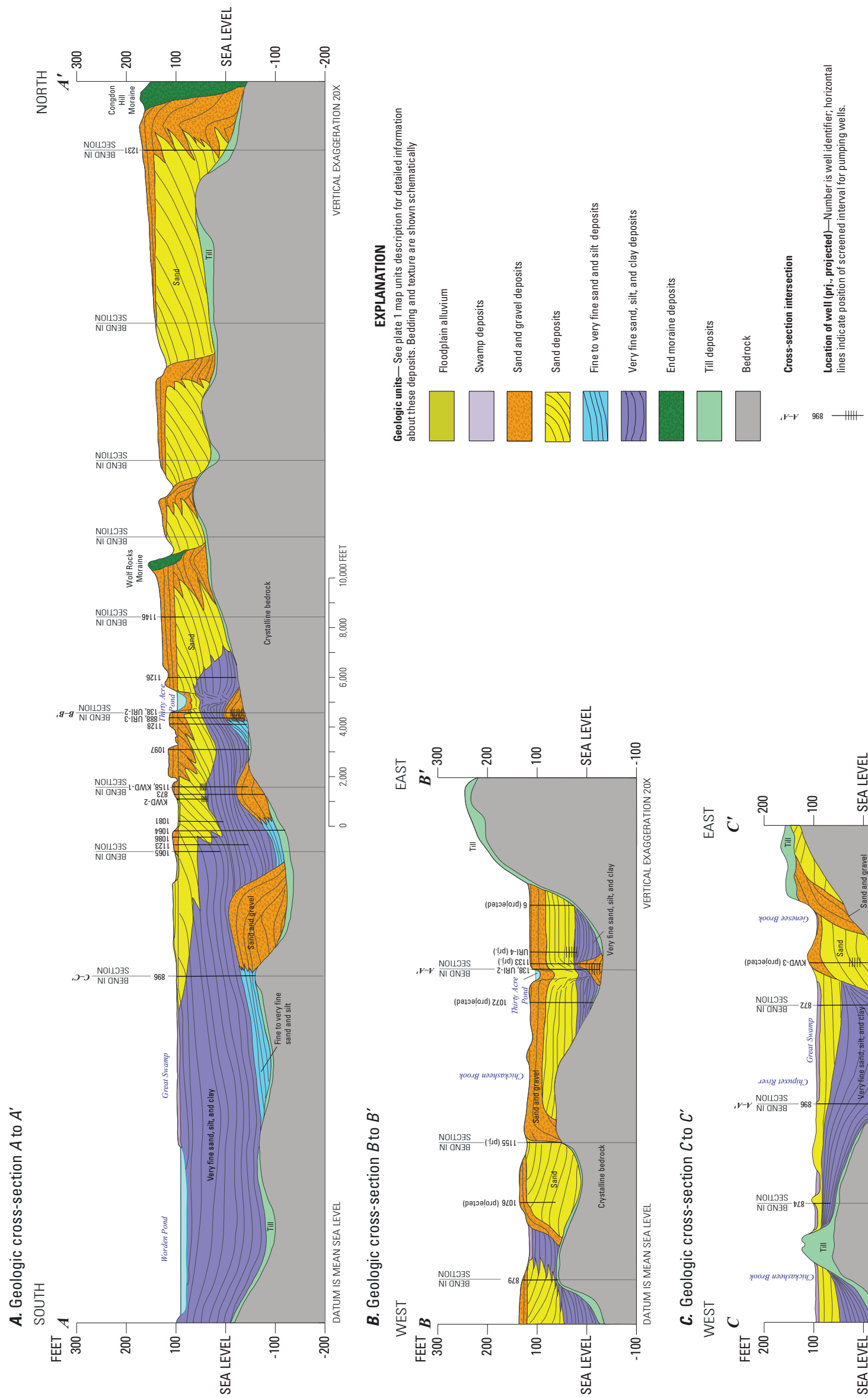

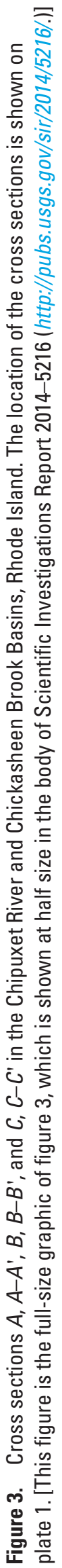




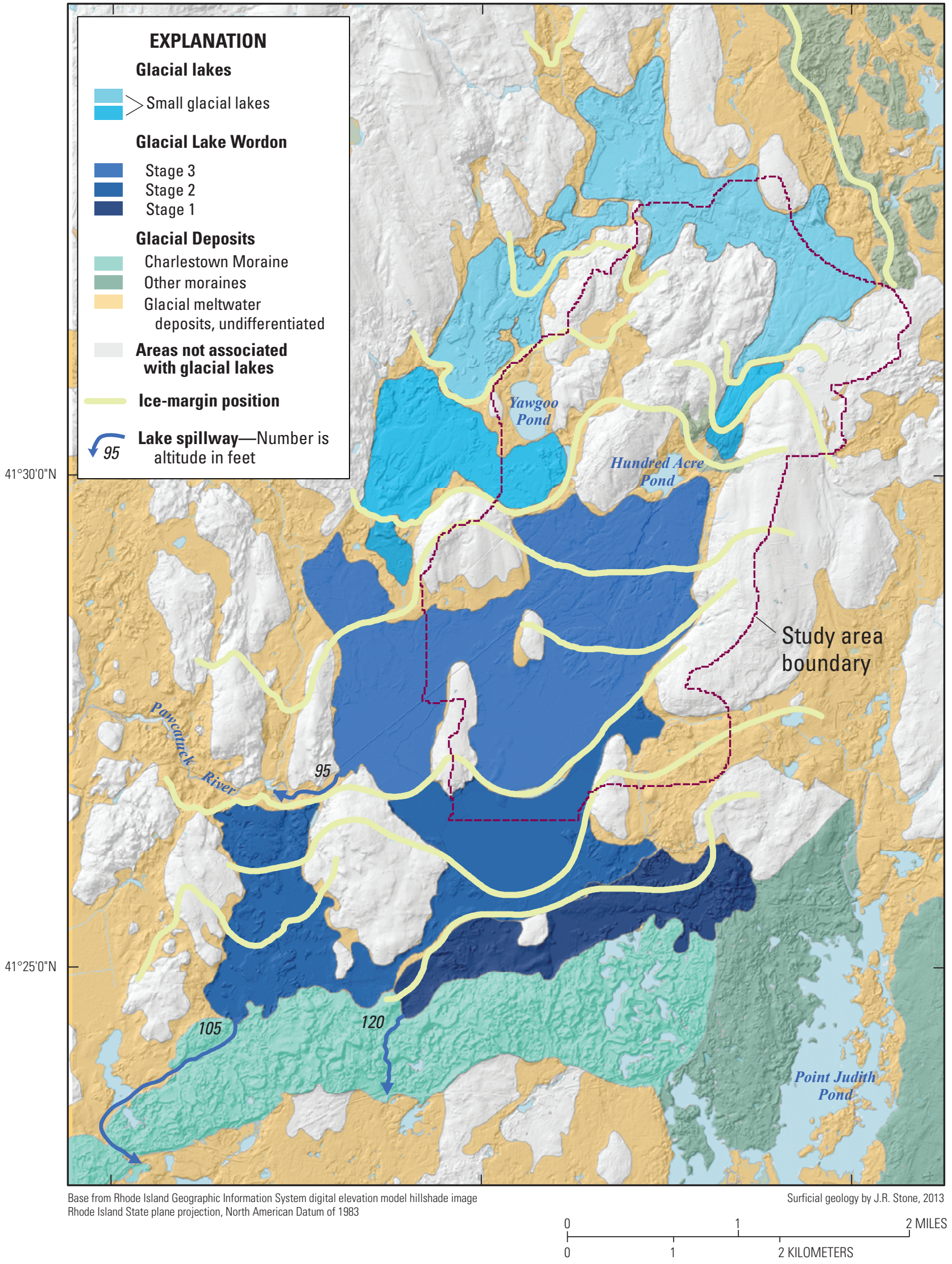

Figure 4. Glacial lakes and retreatal ice-margin positions in the vicinity of the Chipuxet River and Chickasheen Brook Basins, Rhode Island. 
Although no exposures were observed in the study area during recent investigation, lower till observed elsewhere in Rhode Island and Connecticut is typically a gray to olive-gray, very compact mixture of pebbles, cobbles, and few boulders in a sandy matrix that contains up to 30 to 40 percent silt and clay; it is commonly stained with iron oxide. The upper part of lower till sections contain distinct subhorizontal fissility; this fissility and a less well-developed, subvertical, iron- and manganese-stained joint system give the lower till an angular blocky structure.

The upper (late Wisconsinan-age) till was deposited by the last ice sheet. Upper till exposures generally reveal compact, gray to gray-brown, nonoxidized, stony till with a sand and silt matrix. This till is interpreted to be a lodgement facies and exhibits a weakly developed subhorizontal fissility. Where the upper till overlies the lower till, discrete pieces of the oxidized lower till occur as blocks within the matrix of the nonoxidized upper till. Locally, upper till is present as morainal deposits of ablation till. This material accumulated as a nonsorted mixture of sand, gravel, and silt with numerous large boulders directly at the ice front at sequential terminal positions during deglaciation. Ablation till is typically much less compact than lodgement till because the material was melted out of glacial ice at the margin during deglaciation rather than smeared beneath the great weight of the ice sheet as lodgement till. Ablation till occurs in the Chipuxet River valley in moraines such as the Wolf Rocks moraine, the Congdon Hills moraine at the northern end of the study area, and the Charlestown moraine south of the study area. Till overlying sand and gravel deposits south of Genesee Brook in the southeastern part of the study area includes both lodgement and ablation till laid down during a minor readvance of the ice margin in that area.

Till underlies most upland areas in the study area and extends beneath stratified deposits in the valleys. Although not a major aquifer because of small saturated thickness and low hydraulic conductivity, till is nevertheless an important geologic unit in the glaciated region because it affects the circulation of groundwater, particularly rates of recharge to and discharge from underlying bedrock aquifers.

Glacial stratified deposits laid down by meltwater during retreat of the Late Wisconsinan ice sheet about 21,000 years ago overlie till and bedrock in the valleys. These sediments consist of gravel, sand, silt, and clay carried away from the ice front by meltwater streams, which commonly flowed directly or indirectly into glacial lakes. The meltwater deposits consist of mappable bodies of coarse-grained sediment (gravel, sand and gravel, and sand) and fine-grained sediment (very fine sand, silt, and clay). Coarse-grained, poorly sorted, and relatively angular gravel and sand were deposited at and proximal to the ice front. This material was commonly laid down on top of ice at the glacier margin. Subsequent melting of the ice produced "collapsed" ice-contact scarps and kettle holes in these proximal deposits. Finer grained and better sorted gravel and sand was deposited farther away from the ice margin, commonly in deltas that prograded into glacial lakes. Well-sorted very fine sand, silt, and clay settled out as bottom sediments in these lakes. These bodies of contemporaneously deposited sediments, which grade from coarse grained near the ice margin to fine grained in areas distal from the ice, are called morphosequences (Koteff and Pessl, 1981; Stone and others, 2005). Morphosequences in the basin are 0.25 to 4 miles (mi) long and are present in the valley in shingled form; that is, the coarse-grained, collapsed, ice-contact northern part of one sequence is overlain by the fine-grained distal end of the next sequence to the north (fig. $3 A$ ). This shingled relation between morphosequences is the result of sequential deposition related to systematic northward retreat of the margin of the ice sheet during deglaciation. Seven different types of morphosequences are common in southern New England and have been defined in Koteff and Pessl (1981) and Stone and others (2005).

In order to map the distribution of coarse-grained and fine-grained meltwater deposits in an area and to predict textural variations in the subsurface, it is necessary to first understand ice-margin configurations and the associated depositional environments during retreat of the glacier. The highest level (altitude) at which glacial sands and gravels were deposited in particular valleys was controlled by the base level of the meltwater streams during the time of northward ice retreat through the area; these base levels were most commonly a large or small glacial lake into which the meltwater streams flowed. In the south-draining Chipuxet River valley, a series of glacial lakes controlled the levels of meltwater deposition as the ice margin retreated from south to north. In the southern part of the Chipuxet River valley, a relatively large glacial lake existed in modern-day Great Swamp surrounding Worden Pond. Glacial Lake Worden controlled the level of meltwater deposition for the ice-marginal deltaic deposits in the Chipuxet River Basin south of Hundred Acre Pond. The paleoglacial lake was impounded behind the Charlestown Moraine as the ice margin retreated to the north, and the first stage spilled across the moraine through a low channel at about $120 \mathrm{ft}$ in altitude (fig. 4, stage 1). Deltas south of Worden Pond stand at $125 \mathrm{ft}$ in altitude and were graded to this first stage. With continued ice retreat, a lower spillway across the moraine developed to the west at $105 \mathrm{ft}$ altitude; deltas with surfaces at $115 \mathrm{ft}$ in altitude were graded to the second stage of glacial Lake Worden (fig. 4). Further northward ice retreat opened an even lower spillway at 95 to $100 \mathrm{ft}$ altitude westward via the route of the present course of the Pawcatuck River. Several successive ice-marginal lacustrine fans and ice-marginal deltas with surface altitudes of $105 \mathrm{ft}$ were built into the third stage of glacial Lake Worden (fig. 4). North of Hundred Acre Pond at the ice margin position marked by the Wolf Rocks moraine, several small glacial lakes developed successively, each ponded behind ice-marginal sediments of the preceding morphosequence (see shingled relationship of deposits on figs. $3 A, B$.

The glacial stratified deposits in the southern part of the study area consist of a series of three ice-marginal lacustrinefan morphosequences (fig. $3 \mathrm{~A}$ ) laid down sequentially in glacial Lake Worden. The lacustrine fan sediments were deposited where meltwater issued from a tunnel at the base of the 
retreating ice sheet at the bottom of the lake. The ice-proximal (northern) part of each lacustrine fan deposit consists of coarse gravel and sand and each grades to fine sand in distal parts.

The lacustrine fans are overlain by ice-marginal deltaic sands and gravels and extensive lake-bottom silt and clay of glacial Lake Worden.

In the northern part of the Chipuxet River valley, a series of glacial lakes developed, and successive deltas were built up against earlier ones, so that the surface gradient of the meltwater deposits is continuous from one deltaic morphosequence to the next. These deposits are mostly coarse grained; the small successive glacial lakes were filled rapidly with deltaic meltwater sediment, so that extensive fine-grained sediments did not have time to settle out in these lakes. Interfingering sand and gravel deposits and sand deposits are typical in the proximal areas of morphosequences, and interfingering sand deposits and fine deposits are common in distal parts (fig. $3 A$ ).

Production wells URI-2 and URI-3 near Thirty Acre Pond tap water from coarse grained sands and gravels in the proximal part of the third ice-marginal lacustrine-fan morphosequence (figs. $3 A, B$ ). These coarse materials are overlain by fine-grained silt and clay and delta deposits of glacial Lake Worden. Wells KWD-1 and KWD-2 at West Kingston and well URI-4 near Thirty Acre Pond tap water from sandy delta foreset beds above the fine-grained lake-bottom deposits. Well KWD-3 near Genesee Brook (fig. 3C) taps sand that is part of an ice-marginal lacustrine fan which built up to the lake surface and became deltaic with a surface altitude of $115 \mathrm{ft}$ and was associated with the second stage of glacial Lake Worden.

\section{Hydrology}

The headwaters of the Chipuxet River and Chickasheen Brook are in the northern part of the study area; the streams then flow generally southwestward, through Great Swamp, and the Chipuxet River flows into Worden Pond (fig. 1). The Charlestown moraine, deposited across the southern part of the preglacial valley, promoted wetland formation by blocking surface drainage from the north. Major tributaries include White Horn Brook and Genesee Brook. In addition to Worden Pond, the study area contains several large but generally shallow ponds, including Thirty Acre Pond adjacent to the three URI wells.

In the central part of the study area, the Chipuxet River and Chickasheen Brook valleys converge where five of the six production wells are located (fig. 1). Three of these five wells (KWD-1, KWD-2, and URI-4) are screened in coarsegrained stratified deposits composed of mostly sand above the fine-grained deposits; the other two wells (URI-2 and URI-3) are screened in sand and gravel deposits below these finegrained deposits (figs. $3 A, B$ ). Aquifer-pump tests completed in coarse-grained materials at 18 sites in this central part of the study area indicated that horizontal hydraulic conductivities ranged from 90 to more than 500 feet per day (ft/d;
Dickerman, 1984). Maps of horizontal hydraulic conductivities estimated from lithologic logs by Johnston and Dickerman (1985) for that part of the aquifer above the fine-grained deposits indicated horizontal hydraulic conductivities were 50 to $100 \mathrm{ft} / \mathrm{d}$ and sometimes more than $100 \mathrm{ft} / \mathrm{d}$ in this part of the study area. The URI wells are adjacent to the Chipuxet River and Thirty Acre Pond. A layer of silt and organic-rich sediments covers as much as $30 \mathrm{ft}$ in the bottom of the pond at the central part (Dickerman, 1984). A study by Boving and others (2008) using physical, chemical, and biological indicators determined that no more than a small percentage of water from well URI-4 was derived from surface water when pumping at a variable schedule.

The climate in the study area is humid and temperate with an average annual temperature of $49.9^{\circ} \mathrm{F}$ and average annual precipitation of 48.2 inches (in.) from 1950 through 2010 based on a gridded climate dataset developed using a method described by Maurer and others (2002). This dataset, which has a spatial resolution of one-eighth degree, was derived from data from National Oceanic and Atmospheric Administration climatological stations. A subset of the gridded dataset was extracted from the USGS Climate Geo Data Portal (http://cida.usgs.gov/climate/gdp/) for the area that includes the Chipuxet River and Chickasheen Brook Basins. Average monthly precipitation was 4 in. from 1950 through 2010 and was fairly evenly distributed throughout the year, within a range of $3.2 \mathrm{in}$. in July to $4.9 \mathrm{in}$. in March. Average monthly temperature ranged from $29.0^{\circ} \mathrm{F}$ in January to $70.7^{\circ} \mathrm{F}$ in July. The study area has minimal snow accumulation during the winter. This dataset was used to represent climate conditions in the calibrated models for this study as well as the downscaled GCMs.

The source of all water in the study area is ultimately from precipitation. Groundwater generally flows from topographical highs in the uplands toward streams and the valleyfill deposits. The groundwater system is recharged by direct infiltration of precipitation, stream leakage, and wastewater from septic systems. Irrigation return flow is expected to be negligible. Groundwater is decreased by discharges to streams and ponds and by pumping wells. In addition to high-capacity municipal wells, water is withdrawn by domestic wells and by irrigation sites, although most irrigation withdrawals are from surface-water sources. The aquifer is generally in close hydraulic connection with the surface-water system (Johnston and Dickerman, 1985).

Streamflow and water-level records from a USGS long-term network streamgage and from observation wells provide insights into the hydrology of the study area. Mean annual streamflow at the Chipuxet River streamgage (01117350; fig. 1) is 21.2 cubic feet per second $\left(\mathrm{ft}^{3} / \mathrm{s}\right)$. Mean annual base flow (groundwater discharge), calculated by use of the hydrograph-separation technique PART (Rutledge, 1998), was $19.5 \mathrm{ft}^{3} / \mathrm{s}$, or 92 percent of total streamflow. As mentioned in the "Description of the Study Area and Previous Investigations" section, groundwater and surface-water divides do not coincide in the upper part of the Chipuxet River 
Basin; in addition, Johnston and Dickerman (1985) reported that parts of the White Horn Brook and Chickasheen Brook Basins also might be in the groundwater contributing area to the streamgage. Thus, mean annual base flow is approximately equivalent to 26 to 27 inches per year (in/yr) of recharge over the estimated groundwater contributing area. This recharge rate represents an average over the entire contributing area, including areas of stratified deposits, till deposits, morainal deposits, wetlands, ponds, and a variety of land uses. Conceptually, recharge rates for the stratified and morainal deposits are higher than this average rate and lower for less permeable till.

Water levels in observation well SNW6, which is screened in stratified deposits between the Chipuxet River and White Horn Brook (fig. 1), typically fluctuates by 3 to $4 \mathrm{ft}$ on an annual basis. Groundwater levels are generally highest in early spring and lowest in fall. Groundwater-level fluctuations are caused by increased recharge rates from late fall to spring when there is little to no evapotranspiration. Periodic waterlevel measurements in numerous observation wells in stratified deposits in the study area from 1958 to 1959 by Allen and others (1963) indicated that annual water fluctuations ranged from about $1 \mathrm{ft}$ near streams to about $10 \mathrm{ft}$ near the valleyupland contact. Annual water-level fluctuations in till deposits are generally larger because of the smaller storage capacity of till compared with stratified deposits. Water levels in observation well EXW278, which is screened in till deposits in the headwaters of Chipuxet River (fig. 1), typically fluctuates about $15 \mathrm{ft}$ annually. Johnston and Dickerman (1985) reported that water levels fluctuate annually from about $2 \mathrm{ft}$ in low till areas near streams to as much as $20 \mathrm{ft}$ beneath hilltops.

\section{Development of Steady-State and Transient Numerical Models}

Groundwater levels and flows were simulated in the surficial deposits and the underlying bedrock in the Chipuxet River and Chickasheen Brook Basins by using a three-dimensional finite-difference numerical model code MODFLOW-NWT (Niswonger and others, 2011), which is a Newton formulation for MODFLOW-2005 (Harbaugh, 2005). MODFLOW-NWT increases numerical stability and allows for unconfined simulation of thin surficial deposits of steeply sloping hills, such as the uplands bordering the valleys.

A steady-state model and a transient model were developed. Areas at the water table that contribute water to discharge locations, such as pumping wells, are a function of long-term hydraulic gradients in the aquifer. Thus, a steady-state model that represents long-term average annual hydrologic conditions is appropriate for delineating areas contributing recharge to the production wells. The transient model simulated dynamic changes in hydrologic conditions in response to time-varying recharge rates and pumping withdrawals. The transient model was used to simulate the potential effects of climate change on base flow and groundwater levels of the study area.

\section{Steady-State Model}

The steady-state model was calibrated to average annual hydrologic conditions represented by the period 1974 through 2003. This 30 -year period was chosen because (1) the longterm streamgage on the Chipuxet River began operation in 1974, (2) production well KWD-3 began operation in 2004 thereby shifting some of the withdrawals to the Genesee Brook Basin downstream of the streamgage, and (3) average annual precipitation of $48.8 \mathrm{in}$. was close to the $48.2 \mathrm{in}$. of the period of record (1950-2010). Available groundwater-level observations for model calibration, however, were measured in the 1950s. A subset of these groundwater levels that were at or near average groundwater conditions based on USGS longterm network observation wells was selected for calibration. Boundary conditions and hydraulic properties were represented by parameters (table 2) for calibration by nonlinear regression and for evaluating model-prediction uncertainty.

\section{Model Extent and Spatial Discretization}

Groundwater flow in the surficial deposits and underlying bedrock was simulated by a six-layer numerical model with a uniformly spaced finite-difference grid in the horizontal. The geographic extent of the model included most of the Chipuxet River and Chickasheen Brook Basins (fig. 5). The lateral extent of the model coincided with the physical boundaries of the flow system. Topographical divides in the relatively lowpermeability till where groundwater and surface-water divides are most likely to coincide were used for most of the lateral extent. In areas of transmissive deposits, a regional watertable contour map by Allen and others (1966) and simulated regional water-table contours (Masterson, 2011) were used to define the model extent at the groundwater divides. In most of these transmissive deposits, groundwater divides were at or close to surface-water divides. However, as mentioned in the "Description of the Study Area and Previous Investigations" section, Allen and others (1966) determined that groundwater in the northern part of the Chipuxet River Basin flowed to the Annaquatucket River Basin, although there were few data to define the groundwater divide accurately. Part of the southern extent of the model, Worden Pond, is a natural discharge location. The Chipuxet River flows southward through Great Swamp into Worden Pond; west of Worden Pond, the Chipuxet River becomes the Pawcatuck River. Groundwater from north of Worden Pond discharges to the pond and the Chipuxet River, which was routed through the pond to its outlet in the model. South of Worden Pond, water-table maps indicated a groundwater divide between Worden Pond and Block Island Sound located in the Charlestown Moraine (Bierschenk, 1956; Masterson and others, 2007; Friesz, 2010). Groundwater north of this divide flows northward and discharges to Worden Pond. 
Table 2. Definition of model parameters and statistics on parameter values, whether estimated or specified, Chipuxet River and Chickasheen Brook Basins, Rhode Island.

[ft/d, feet per day; in/yr, inches per year; --, dimensionless or not applicable]

\begin{tabular}{|c|c|c|c|c|c|}
\hline $\begin{array}{l}\text { Parameter } \\
\text { name }\end{array}$ & Parameter description & Units & $\begin{array}{l}\text { Optimal or } \\
\text { specified } \\
\text { value }\end{array}$ & $\begin{array}{c}\text { 95-percent } \\
\text { confidence } \\
\text { interval range }\end{array}$ & $\begin{array}{c}\text { Coef- } \\
\text { ficient of } \\
\text { variation }{ }^{1}\end{array}$ \\
\hline \multicolumn{6}{|c|}{ Estimated by nonlinear regression } \\
\hline K_MOR & Horizontal hydraulic conductivity of morainal deposits & $\mathrm{ft} / \mathrm{d}$ & 36.9 & $27.5-49.1$ & 0.15 \\
\hline K_SAND & Horizontal hydraulic conductivity of stratified sand deposits & $\mathrm{ft} / \mathrm{d}$ & 155 & $95.5-257$ & 0.26 \\
\hline K_S\&G & Horizontal hydraulic conductivity of stratified sand and gravel deposits & $\mathrm{ft} / \mathrm{d}$ & 99.3 & $67.6-144$ & 0.20 \\
\hline \multicolumn{6}{|c|}{ Specified by prior information from the literature } \\
\hline K_FINE & Horizontal hydraulic conductivity of stratified fine-grained deposits & $\mathrm{ft} / \mathrm{d}$ & 20 & $4-102$ & -- \\
\hline K_ROCK & Horizontal hydraulic conductivity of bedrock & $\mathrm{ft} / \mathrm{d}$ & 0.1 & -- & -- \\
\hline K_SW & Horizontal hydraulic conductivity of surface water & $\mathrm{ft} / \mathrm{d}$ & 50,000 & -- & -- \\
\hline KV_PDPT & $\begin{array}{l}\text { Ratio of horizontal to vertical hydraulic conductivity of pond-bottom sedi- } \\
\text { ments and peat (or in relation to horizontal hydraulic conductivity of } 1 \mathrm{ft} / \mathrm{d} \text { ) }\end{array}$ & -- & $\begin{array}{l}100 \\
(0.01)\end{array}$ & $\begin{array}{c}759-13 \\
(0.001-0.08)\end{array}$ & -- \\
\hline KV_ROCK & Ratio of horizontal to vertical hydraulic conductivity of bedrock & -- & 1 & -- & -- \\
\hline KV_SURF & Ratio of horizontal to vertical hydraulic conductivity of glacial deposits & -- & 10 & $2-48$ & -- \\
\hline R_MULT & Multiplier of recharge rate on glacial and postglacial deposits & -- & 1.0 & $0.85-1.15$ & -- \\
\hline R_SW & Recharge rate on surface water & in/yr & 19.8 & -- & -- \\
\hline SB_K & Vertical hydraulic conductivity of streambed deposits & $\mathrm{ft} / \mathrm{d}$ & 3 & $1.1-8.1$ & -- \\
\hline
\end{tabular}

${ }^{1}$ Dimensionless.

The active model represented an area of $24.4 \mathrm{mi}^{2}$, consisted of 318 rows and 242 columns, and it included a total of 260,886 cells each with $125 \mathrm{ft}$ on a side.

Vertical discretization was based on surface-water features, lithology, and placements of the production well screens (pl. 1; fig. 3). The top two layers (layers 1 and 2) were relatively thin to represent ponds and wetlands and to simulate shallow groundwater flow near surface water accurately. The bottom of layer 1 was $5 \mathrm{ft}$ below land surface or pond surface. Layer 2 was generally $1 \mathrm{ft}$ thick to represent fine-grained pond-bottom sediments or highly decomposed wetland peat deposits except beneath Thirty Acre Pond, which is adjacent to the URI production wells, where it ranged from $1 \mathrm{ft}$ near the edge of the pond to $30 \mathrm{ft}$ in the center based on field measurements by Johnston and Dickerman (1985). Layer 3 represented 50 percent of the thickness of the remaining deposits and layer 4 and 5 each represented 25 percent; the production wells are screened in these three layers. Stratified, morainal, and till deposits are represented in all five layers. Shallow bedrock areas less than $9 \mathrm{ft}$ from the land surface were incorporated into surrounding surficial materials. The bottom layer (layer 6) represented bedrock with a constant thickness of $200 \mathrm{ft}$ throughout the model beneath the surficial deposits. The bottom layer allows for flow in bedrock areas where surficial deposits are thin, such as beneath the uplands.

\section{Hydrologic Boundaries}

Hydrologic boundaries include the movement of water into and out of the groundwater-flow model. These hydrologic boundaries include recharge from precipitation, the interaction between streams and aquifers, and well withdrawals. Water-balance methods were used to calculate recharge rates to surficial deposits and ponds. The gridded climate data developed by Maurer and others (2002) were used in the two water-balance methods. All external boundary cells adjacent to the groundwater divides, adjacent to Worden Pond, a natural discharge boundary, and beneath the bottom of the simulated bedrock were defined as no-flow boundaries. 


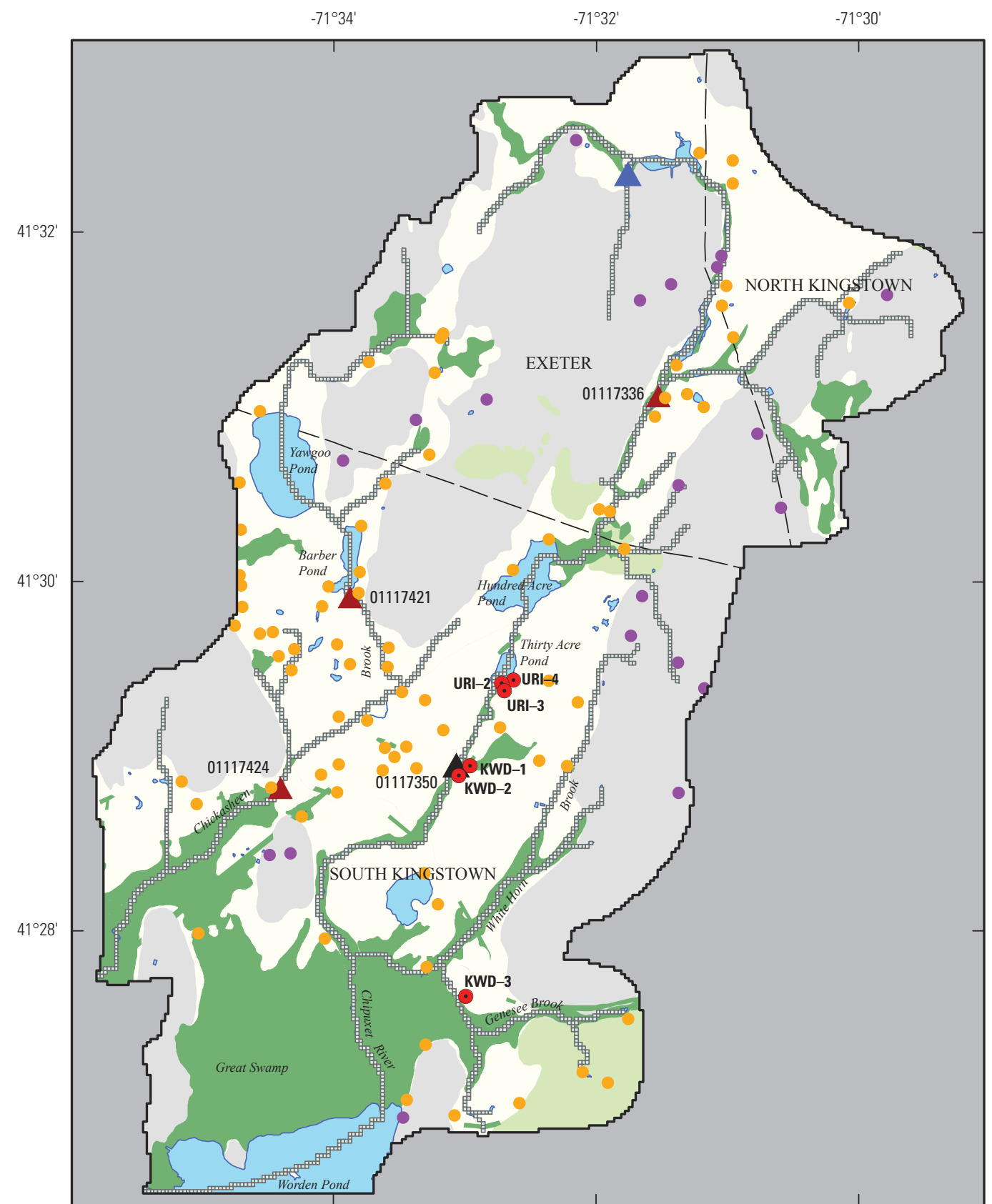

Base from U.S. Geological Survey 1:24,000 topographic maps, 1995 and 2001 Rhode Island State plane projection North American Datum of 1983

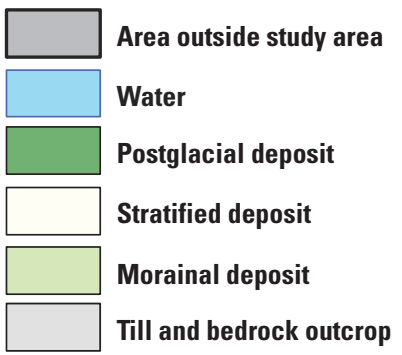

Stream cells
EXPLANATION

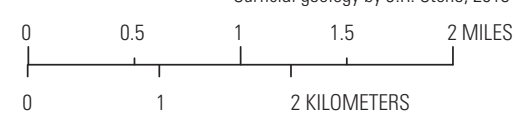

\section{Streamgage}

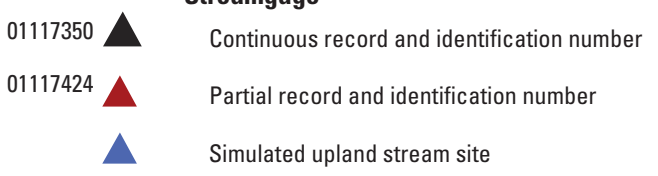

KWD-3 Production well and identification number Groundwater level observations Group A Group B

Figure 5. Groundwater-level observations, streamgages with continuous and partial records, and model stream cells in the Chipuxet River and Chickasheen Brook Basins, Rhode Island. The area outside the study area was designated as a no-flow boundary in the groundwater-flow model. 


\section{Recharge}

Two parameters defined recharge in the groundwaterflow model (table 2) — one for the groundwater recharge rates as determined by a soil-water-balance model and one for pond recharge. R_MULT is a dimensionless parameter that multiplies the recharge rates determined for the surficial materials. This parameter was not considered for calibration by nonlinear regression; instead, the uncertainty in these recharge rates was included in the probabilistic contributing area analysis. R_MULT was specified a value of 1 , which is equal to the recharge rates as determined from the soil-waterbalance model. A recharge rate to ponds, defined by parameter R_SW, was also not considered for parameter estimation but was instead specified for both calibration and the uncertainty analysis. R_SW was specified as $19.8 \mathrm{in} / \mathrm{yr}$ by subtracting the average annual evaporation rate from a free-water surface for southern Rhode Island (29 in/yr; Farnsworth and others, 1982) from the average annual precipitation rate (48.8 in/yr).

The spatial and temporal variation in recharge to surficial materials was calculated by using a Thornthwaite-Mather soilwater-balance model (SWB) (Westenbroek and others, 2010). The model code is based on a modified Thornthwaite-Mather SWB method (Thornthwaite and Mather, 1957) and it uses climate variables and spatially distributed variables such as soil type, land use, and soil water capacity. Components of the SWB were calculated at a daily time step for each model cell; the horizontal grid of the SWB model was the same as the groundwater-flow model.

Daily recharge was calculated in the SWB model as the difference between the change in soil moisture and water sources and losses (Westenbroek and others, 2010). Sources of water include precipitation and snowmelt and losses include plant interception, surface runoff, and actual evapotranspiration. Plant interception is rainfall captured by vegetation and evaporated or transpired from their surfaces and is related to land use and season. Surface runoff is determined by the Natural Resources Conservation Service (NRCS) curve number rainfall-runoff method (Cronshey and others, 1986) and is related to soil type, land use, and antecedent runoff condition. Evapotranspiration from the root zone is a function of temperature, soil type, and vegetation. Actual evapotranspiration is calculated from potential evapotranspiration and the available soil moisture. If precipitation exceeds potential evapotranspiration, then actual evapotranspiration equals potential evapotranspiration. If potential evapotranspiration exceeds precipitation, then actual evapotranspiration is equal to precipitation and the quantity of water that can be extracted from the soil. Recharge is the surplus water in the root zone of the soil. A detailed description of the method is available in the SWB model documentation (Westenbroek and others, 2010).

Soil type was based on glacial and postglacial surficial deposits (pl. 1). The NRCS defines four hydrologic soil types (A-D) based on infiltration capacity (Cronshey and others, 1986). Hydrologic soil type A has a high infiltration capacity (more than $0.30 \mathrm{in} / \mathrm{hr}$ ) and a low surface runoff potential, whereas hydrologic soil group D has low infiltration capacity (less than $0.05 \mathrm{in} / \mathrm{hr}$ ) and a high runoff potential. The coarsegrained stratified deposits (sand; sand and gravel), morainal deposits, and alluvial deposits were assigned hydrologic soil type A, upper till deposits were assigned type B, and wetland deposits of peat were assigned type $\mathrm{C}$. The fine-grained stratified deposits and the lower till deposits (thick till) were covered by other surficial deposits.

Seventeen land-use categories for urban, agriculture, and undeveloped land cover were used in the SWB model (fig. 2); the land use in the figure is shown in 10 categories for clarity. This data represent land use in 2003 and 2004. The predominant land cover in the study area is forest.

Initial input values for the SWB model, such as NRCS runoff curve numbers derived from Cronshey and others (1986) and root zone depth derived from Thornthwaite and Mather (1957), were iteratively modified to improve the fit between long-term mean annual recharge (1974-2003) calculated by the SWB model and (1) base flow calculated for the Chipuxet River streamgage (01117350) and (2) recharge values from the literature. For forested (undeveloped) land cover, literature values were compared with recharge rates determined by the SWB model. Total recharge calculated by the calibrated SWB model for the groundwater contributing area to the Chipuxet River streamgage was within 5 percent of base flow. The recharge rate of $23.4 \mathrm{in} / \mathrm{yr}$ to forested land cover in upland till was within the range of recharge rates calculated from hydrograph-separation techniques from till-dominated watersheds in southern New England (16 to 24 in/yr; Bent, 1995, 1999; Friesz and Stone, 2007). This recharge rate to forested land cover in upland till and the $29.1 \mathrm{in} / \mathrm{yr}$ recharge rate to forested land cover in coarse-grained stratified deposits were within the range of values determined by groundwaterflow models, calibrated either manually or by parameter estimation, for till (19 to $24 \mathrm{in} / \mathrm{yr}$ ) and stratified deposits (27 to $33 \mathrm{in} / \mathrm{yr}$ ) in and adjacent to the study area (Dickerman and others, 1997; Barlow and Dickerman, 2001; Masterson and others, 2007; Friesz, 2010, 2012; Masterson, 2011).

Mean annual recharge rates calculated by the SWB model from 1974 through 2003 ranged spatially from $15 \mathrm{in} / \mathrm{yr}$ to more than 31 in/yr (fig. 6). In general, lower recharge rates were calculated for sediments with low infiltration capacity and developed land cover and higher rates for sediments with high infiltration capacity and undeveloped land cover. The mean annual recharge rate averaged spatially over the entire study area was $25.0 \mathrm{in} / \mathrm{yr}$ or 51 percent of mean annual precipitation. The largest component of water loss before recharge was evapotranspiration at $17.9 \mathrm{in} / \mathrm{yr}$ or 37 percent. The remaining components of water loss before recharge, plant interception and surface runoff, were each about 3 in/yr or 6 percent of mean annual precipitation. The total of evapotranspiration and plant interception rates was within the range of values calculated for southern Rhode Island by Sanford and Selnick (2013). Information on average monthly recharge rates is found in the "Transient Model" section. 


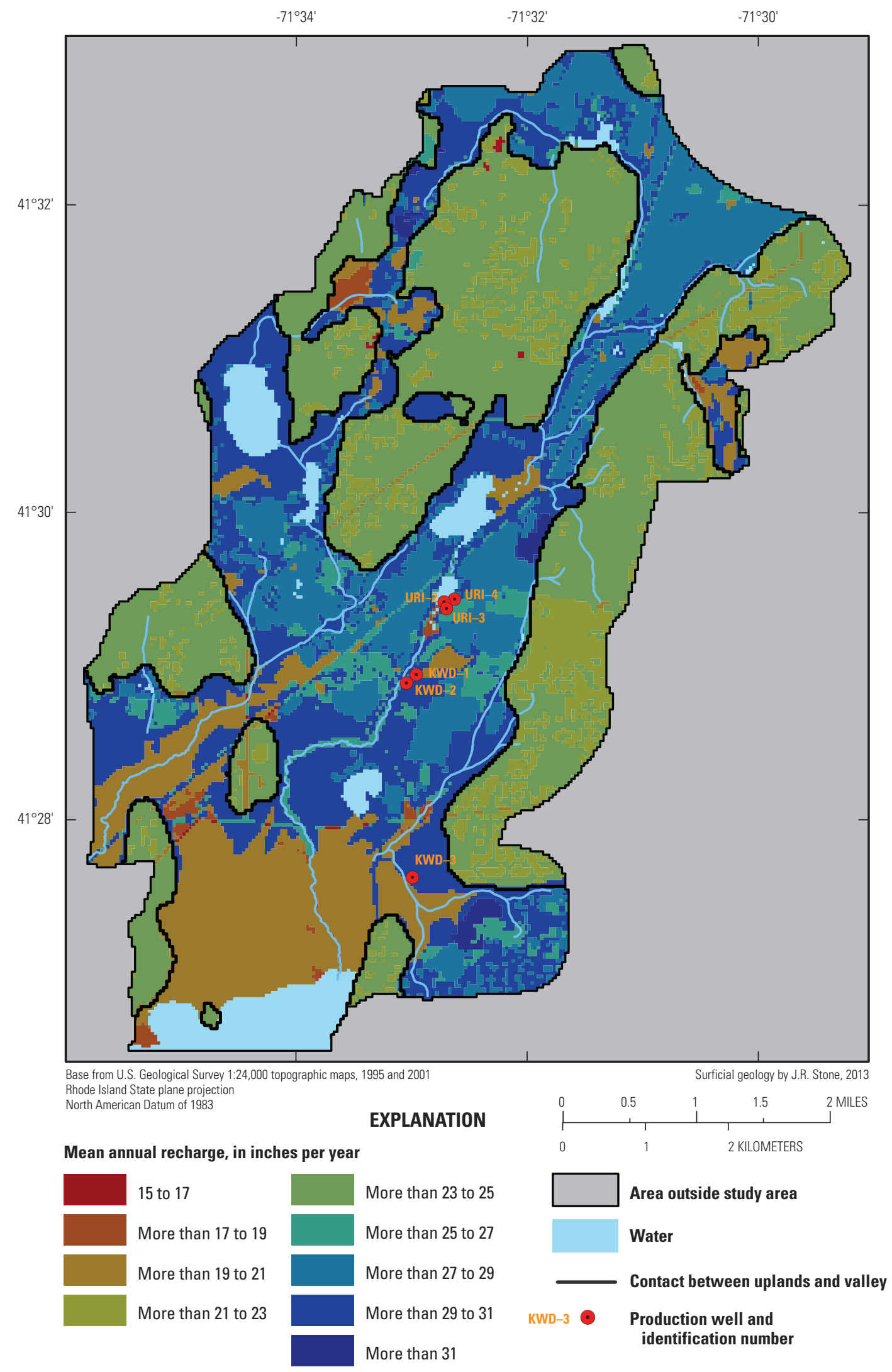

Figure 6. Mean annual recharge from 1974 through 2003 in the Chipuxet River and Chickasheen Brook Basins, Rhode Island. 


\section{Stream-Aquifer Interactions}

Stream-aquifer interactions were simulated as a headdependent flux boundary in layer 1 (fig. 5) by using the streamflow-routing package (Niswonger and Prudic, 2005) developed for MODFLOW. The streamflow-routing package accounts for gains and losses of water in each stream cell and routes streamflow from upstream cells to downstream cells. Streams that flow into and out of ponds were simulated as flowing through these water bodies. Stream altitudes were determined from or interpolated between topographical contours that intersected streams and pond altitudes listed on USGS Kingston and Slocum topographic quadrangles. Each streamflow-routing cell requires a conductance term that incorporates the geometry and vertical hydraulic conductivity of the streambed. Water depths and bed thicknesses of $1 \mathrm{ft}$ were used to determine the top and bottom bed altitudes from surface-water altitudes. Simulated streams were assigned widths ranging from $10 \mathrm{ft}$ for small tributaries, $20 \mathrm{ft}$ and $30 \mathrm{ft}$ for most of the main stems of Chickasheen Brook and the Chipuxet River, respectively, and $40 \mathrm{ft}$ for Chickasheen Brook and the Chipuxet River in Great Swamp in the southernmost part of the study area. The Chipuxet River and Chickasheen Brook exit the model in the south and southwest. Stream lengths were assigned $125 \mathrm{ft}$, which is the model cell dimension. A parameter, SB_K (table 2) defined the vertical hydraulic conductivity of the streambed materials. The model contained a total of 1,925 streamflow-routing cells.

\section{Water Withdrawals and Return Flow}

Average annual withdrawal rates from 1995 through 2003 at the KWD and URI production wells (table 1) were assumed to represent average rates for the calibration period (1974-2003). Wild and Nimiroski (2004) and Bent and others (2011) reported that for 1995-99 and 2000-03, respectively, withdrawals averaged about 300 gallons per minute (gal/min; $0.67 \mathrm{ft}^{3} / \mathrm{s}$ ) for each water supplier. Johnston and Dickerman (1985) also reported total withdrawals of $600 \mathrm{gal} / \mathrm{min}$ $\left(1.34 \mathrm{ft}^{3} / \mathrm{s}\right)$ by the two water suppliers for 1979 , although the URI had a higher withdrawal rate than the KWD.

Water withdrawn by the URI well field, which is mostly used by a student population, is used in sewered areas and then exported out of the Chipuxet River Basin (Robert Bozikowski, Water System Manager, University of Rhode Island, written commun., 2012). Water withdrawn by the KWD wells is used for domestic, commercial, and industrial purposes as well as irrigation for turf farming (20 percent) (Wild and Nimiroski, 2004). About 50 percent of the water withdrawn by the KWD wells is used in sewered areas and exported out of the study area (Henry Meyer, Manager, Kingston Water District, oral commun., 2012). Water used for irrigation is assumed to be lost to evapotranspiration. Most of the remaining pumped water is returned to groundwater through septic systems, including some areas outside the study area. Wild and Nimiroski (2004) estimated that 85 percent of the water used by domestic population on septic systems is returned to groundwater and 15 percent is consumed. Thus approximately $70 \mathrm{gal} / \mathrm{min}\left(0.16 \mathrm{ft}^{3} / \mathrm{s}\right)$ of water withdrawn by the production wells is returned to the aquifer in the study area. For this study, return flow through septic systems was not simulated in the model. Areas contributing recharge to the production wells, therefore, might represent slightly larger, more conservative estimates of areas than if return flow had been included in the model.

Withdrawals from small-capacity domestic wells and irrigation sites were not included in model simulations. Most pumped water from domestic wells is returned to the aquifer through nearby onsite septic systems with little net change in flow. Irrigation withdrawals by private landowners, which is also mostly for turf farming, averaged about $170 \mathrm{gal} / \mathrm{min}$ $\left(0.38 \mathrm{ft}^{3} / \mathrm{s}\right)$ from 1995 through 2003 (Wild and Nimiroski, 2004; Bent and others, 2011) and about $70 \mathrm{gal} / \mathrm{min}\left(0.15 \mathrm{ft}^{3} / \mathrm{s}\right.$; Johnston and Dickerman, 1985) for 1979. However, irrigation withdrawals (about 90 percent) were from surface water and assumed to be consumed through evapotranspiration with no recharge to groundwater.

\section{Hydraulic Properties}

Hydraulic conductivity parameters were assigned on the basis of lithologic units (fig. 3; table 2; pl. 1). Horizontal hydraulic conductivity of glacial stratified deposits was represented by three parameters: K_SAND, K_S\&G, and K FINE. The generally thin till in the valleys was incorporated into adjoining stratified deposits. K_SAND represented stratified sand deposits and K_S\&G represented stratified sand and gravel deposits; these two coarse-grained units occur throughout most of the valleys in the study area. K_FINE represented the remaining stratified deposits, lacustrine deposits associated with glacial Lake Worden beneath Worden Pond and Great Swamp. These fine deposits extend northward at depth beneath production wells KWD-1 and KWD-2 and as an intervening layer between coarse-grained stratified deposits above the production well screens of wells URI-2 and URI-3. Upland till was represented by two parameters: K_TILL and K_TKTILL. K_TILL represented the loose to moderately compact, generally sandy till. K_TKTILL represented the moderate to very compact thick till that is finer grained than K_TILL. The morainal deposits in the central and southeastern part of the study area were represented by K_MOR.

Horizontal hydraulic conductivity of bedrock was represented by parameter K_ROCK, wetlands were defined by K_WETLD, and ponds were defined by K_SW. Values for both K_WETLD and K_SW were specified in the model but not considered for parameter estimation. Wetlands and ponds were set at high values to simulate the flat gradient across these features. Great Swamp was set to $20,000 \mathrm{ft} / \mathrm{d}$ based on manual calibration and the remaining smaller wetlands were fixed at 1,000 ft/d; both these values are within the range of values that Masterson and others (2007) simulated for wetlands in southern Rhode Island. Conceptually, K_WETLD represented groundwater flow through any large interconnected 
pores in poorly decomposed peat in the top part of the peat. Model cells containing the ponds were assigned the highest value in the model at $50,000 \mathrm{ft} / \mathrm{d}$.

The ratio of horizontal hydraulic conductivity to vertical hydraulic conductivity for glacial deposits, postglacial deposits (pond-bottom sediments and highly decomposed peat), and bedrock was each represented by one parameter, KV_SURF, KV_PDPT, and KV_ROCK, respectively. Initially, the vertical anisotropy of stratified, till, and morainal deposits were each represented by a parameter. Because initial results from parameter estimation indicated that all three parameters were insensitive to the available observations and because there were few data in the literature on the vertical anisotropy of till and morainal deposits, in the final model simulations all three glacial deposits were represented by the one parameter: KV_SURF. The horizontal hydraulic conductivity of pondbottom sediments and of peat was held constant in layer 2 at $1 \mathrm{ft} / \mathrm{d}$; therefore, the ratio is always in relation to this value. Parameter KV_PDPT, which represents fine-grained deposits at the bottom of the ponds and the highly decomposed peat at depth, controls the connection between the ponds and wetlands and the underlying aquifer.

\section{Observation Data}

Parameter values in the groundwater-flow model were estimated using 98 groundwater-level observations and 2 baseflow (groundwater discharge) observations. Observations were weighted on the basis of methods described by Hill and Tiedeman (2007); the weights accounted for measurement error and for the difference in units between groundwater levels and base flows. More accurate observations were given larger weights than less accurate observations and thus had more influence in the regression and on the estimated parameter values than the less accurate observation data. Different weights also allowed for more observations to be included in the regression. Observation weights are equal to the inverse of the variance (square of the standard deviation) of the measurement error. The standard deviation of the measurement error is equal to the accuracy of the measurement divided by the 95 -percent confidence interval (1.96) for a normal distribution.

Groundwater-level observations used in model calibration were selected from available groundwater levels compiled from previous USGS investigations (Bierschenk, 1956; Hahn, 1959; Allen and others, 1963) that were at or near average groundwater-level conditions. Groundwater-level conditions were determined by the long-term observation well SNW6 in the central part of the study area and long-term observation well CHW18 in southern Rhode Island for measurements that preceded those for observation well SNW6 (fig. 1). Water levels have been measured since February 1955 at well SNW6 and since October 1946 at well CHW18. Both observation wells are screened in valley-fill deposits. Most of the groundwater-level observations used in model calibration were measured in shallow dug wells August and November through
December 1954 and August 1959. During August, water levels would typically be at below-average long-term conditions, but because of above-average precipitation in the months preceding August for 1954 and 1959, water levels in the aquifer were at or near average conditions.

Groundwater-level observations were divided into two groups (A and B) depending on their estimated accuracy (fig. 5). Group A included 78 groundwater levels measured in the valley-fill deposits and Group B included 20 groundwater levels measured in upland till deposits. The altitudes of the measuring points for both groups were based on the altitude of the land surface; for this study, the altitude of the land surface was determined from light detection and ranging (lidar) imagery, which has a fundamental vertical accuracy of $1 \mathrm{ft}$ at the 95-percent confidence interval (Rhode Island Geographic Information System, 2011). For observations from Group B, which are from wells in the uplands where landsurface topography is steeper than in the valley and where the exact location of the well might not be known (thereby adding more uncertainty to the altitude of the measuring point), an accuracy within $4 \mathrm{ft}$ was used. The standard deviation of the measurement error ranged from $0.51 \mathrm{ft}$ for Group A to $2.04 \mathrm{ft}$ for Group B. Corresponding observation weights ranged from 3.84 per square foot $\left(\mathrm{ft}^{-2}\right)$ for Group A to $0.24 \mathrm{ft}^{-2}$ for Group B.

Long-term mean annual base flow from 1974 through 2003 calculated at three partial-record streamgages (01117336, 01117421, and 01117424) and at the Chipuxet River continuous streamgage (01117350; figs. 1 and 5) was used for two base-flow observations. The two observations, one on the Chipuxet River and one on the Chickasheen Brook, represented the net base flow gain between streamgages.

An equation that related streamflow at a partial-record streamgage to that at a continuous streamgage (Beaver Brook streamgage, 01117468; fig. 1) was computed for each partial-record streamgage by Bent and others (2014). Mean annual base flow at Beaver Brook streamgage was entered into the equations to estimate the corresponding base flow at the partial-record streamgages. Base flow at Beaver Brook streamgage was calculated by use of the automated hydrograph-separation technique PART (Rutledge, 1998). Although they might have been affected by groundwater withdrawals, streamflow records at the Chipuxet River streamgage were also used to determine mean annual base flow for the calibration period from 1974 through 2003 with the hydrographseparation technique.

The accuracy of the mean annual base flow at the partialrecord streamgages was estimated to be 10 percent, and at the Chipuxet River streamgage, 5 percent. Because the gain in base flow was determined from an upstream and a downstream streamgage, the variance of the errors of the two base flow estimates was summed. The coefficient of variation (standard deviation divided by the mean) from which the observation weight was calculated was 0.09 ( 9 percent) for the base-flow observation on the Chipuxet River and 0.19 (19 percent) for the base-flow observation on the Chickasheen Brook. 


\section{Calibration}

The steady-state groundwater-flow model was calibrated with the inverse modeling program UCODE-2005 (Poeter and others, 2005; Hill and Tiedeman, 2007) using nonlinear regression that minimizes the differences, or residuals, between field (observed) and simulated water levels and base flows to obtain an optimal set of parameter values. The quality of this calibration was determined by analysis of the residuals and the accuracy of the estimated parameter values. Some parameters, however, might be insensitive to the available observations and some parameters might be highly correlated with each other and therefore cannot be estimated by nonlinear regression. Values from the literature (prior information) were used to specify parameter values that could not be estimated by nonlinear regression.

\section{Estimation of Model Parameters}

Eleven model parameters were evaluated with parameter estimation: seven for horizontal hydraulic conductivity
(K_SAND, K_S\&G, K_FINE, K_MOR, K_TILL, K_TKTILL, and K_ROCK), three for vertical anisotropy (KV_PDPT, KV_ROCK, KV_SURF), and one for streambed vertical hydraulic conductivity (SB_K) (table 2). Recharge parameter R_MULT was not considered for parameter estimation, but the uncertainty in the recharge values was included in the uncertainty analysis of the areas contributing recharge to the production wells. Parameter sensitivities, shown by their composite scaled sensitivities in figure 7, indicate whether groundwater-level and baseflow observations provided sufficient information to permit an estimate of a given parameter (Hill and Tiedeman, 2007). Parameters with higher sensitivities generally can be more precisely estimated than can parameters with lower sensitivities. Parameters with composite-scaled sensitivities that are about two orders of magnitude lower than that of the parameter with the highest value, or those with compositescaled sensitivities less than one, indicate that nonlinear regression might not be capable of estimating the parameter (Hill and Tiedeman, 2007).

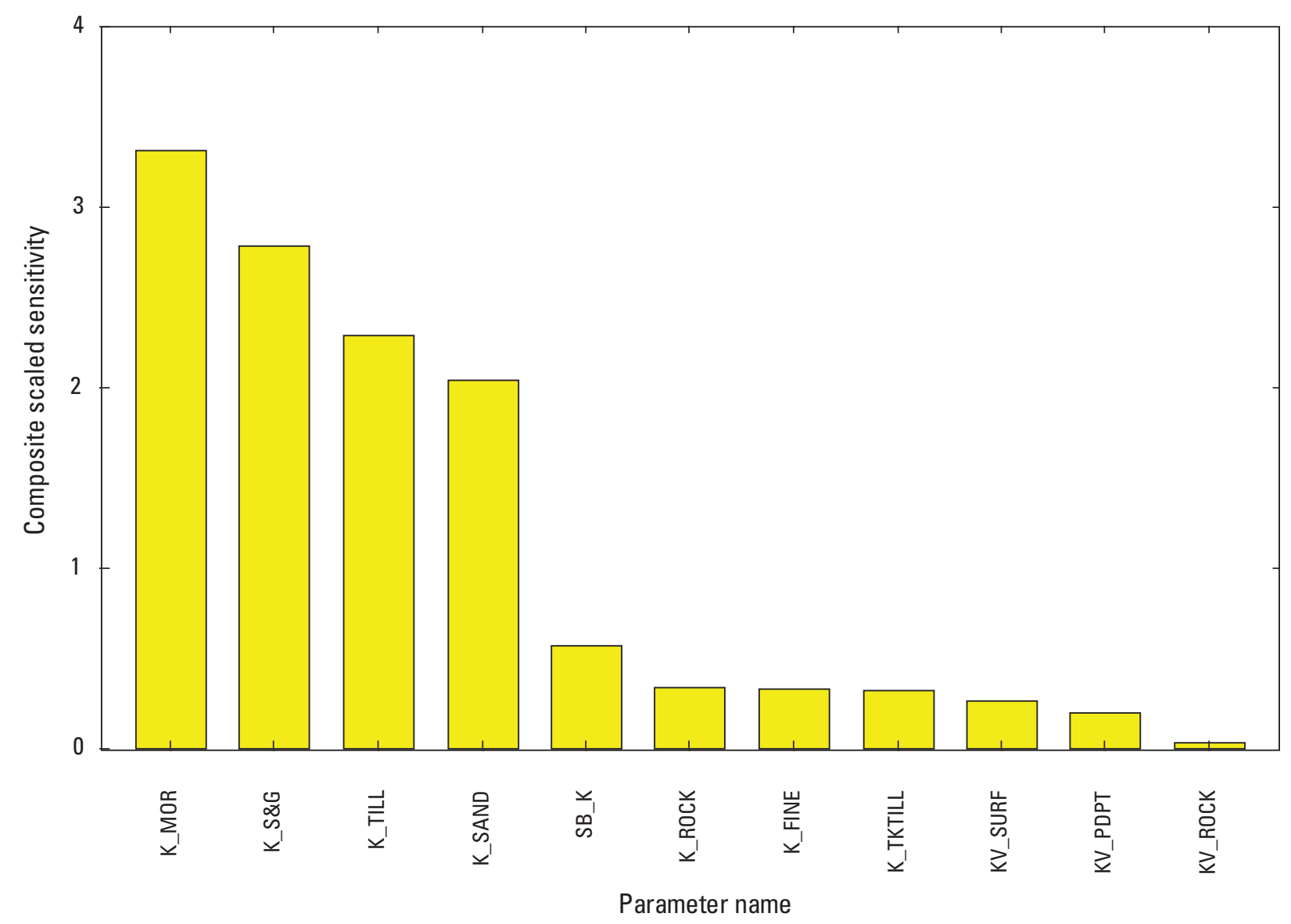

Figure 7. Composite scaled sensitivities for model parameters, Chipuxet River and Chickasheen Brook Basins, Rhode Island. Parameters are listed in table 2. 
Low sensitivities were associated with seven parameters; thus, these parameters were assigned values from prior information in the literature. Two of the parameters representing the horizontal hydraulic conductivity of glacial deposits had low sensitivities (K_FINE and K_TKTILL). Horizontal hydraulic conductivity values of stratified deposits have been estimated for lithology based on the relation between hydraulic conductivity and grain size as determined by Rosenshein and others (1968) and modified by Dickerman (1984) from aquifer-test results. These values have since been used in most Rhode Island groundwater studies: $4 \mathrm{ft} / \mathrm{d}$ for silt, $20 \mathrm{ft} / \mathrm{d}$ for very fine sand, $50 \mathrm{ft} / \mathrm{d}$ for fine sand, $100 \mathrm{ft} / \mathrm{d}$ for sand, $200 \mathrm{ft} / \mathrm{d}$ for sand and gravel, and $500 \mathrm{ft} / \mathrm{d}$ for gravel. Parameter K_FINE was specified a value of $20 \mathrm{ft} / \mathrm{d}$ representative of very fine sand. Hydraulic properties of till are highly variable. Aquifer tests and laboratory measurements indicated that hydraulic conductivity values for till in the upper Pawcatuck River Basin range from 0.1 to $41 \mathrm{ft} / \mathrm{d}$ (Allen and others, 1966). Melvin and others (1992) summarized the hydraulic properties of till from previous studies in southern New England. For till derived from crystalline bedrock, horizontal hydraulic conductivities ranged from 0.1 to $65 \mathrm{ft} / \mathrm{d}$. Parameter K_TKTILL, which conceptually should have a lower value than K_TILL, was assigned a value at the low end of these reported ranges at $5 \mathrm{ft} / \mathrm{d}$ and lower than the initial value determined from nonlinear regression for K_TILL.

Both parameters representing the ratios of horizontal to vertical hydraulic conductivity of surficial deposits (KV_SURF and KV_PDPT) had low sensitivities. For stratified deposits, vertical anisotropy ranged from 2 to 80 on the basis of aquifer-test analyses in the Chipuxet River Basin by Dickerman (1984) and in a tributary basin to the Pawcatuck River Basin by Dickerman and others (1990), averaging 10 and 6 in these studies, respectively. A value of 10 was specified for KV_SURF, which represented all glacial surficial deposits. For peat deposits, Verry and Boelter (1979) reported hydraulic conductivity values from an extensive study in Minnesota that varied over several orders of magnitude, from less than $0.03 \mathrm{ft} / \mathrm{d}$ to more than $4 \mathrm{ft} / \mathrm{d}$. A vertical hydraulic conductivity of $0.01 \mathrm{ft} / \mathrm{d}$ was determined for peat from aquifertest results in an adjoining basin (Friesz, 2010); this value was used for this study. Because the anisotropy ratio for KV_PDPT is always in relation to a horizontal hydraulic conductivity of 1 , the resulting ratio was equal to $100: 1$.

Low sensitivities were also associated with bedrock parameters K_ROCK and KV_ROCK. Hydraulic conductivity of crystalline bedrock is generally low. Analysis of specific capacity data from bedrock wells in eastern Connecticut indicated an average hydraulic conductivity of $0.5 \mathrm{ft} / \mathrm{d}$ (Randall and others, 1966). Lower values of 0.02 and $0.09 \mathrm{ft} / \mathrm{d}$ for crystalline bedrock in northern New Hampshire were determined through model calibration (Tiedeman and others, 1997). Parameter K_ROCK was specified a value of $0.1 \mathrm{ft} / \mathrm{d}$, and KV_ROCK was specified a ratio of 1 (table 2).

The final low-sensitivity parameter was for the vertical hydraulic conductivity of streambeds (SB_K). Streambeds in the upper Pawcatuck River Basin are generally composed of coarse-grained sediments (Allen and others, 1966). Field measurements of streambed vertical hydraulic conductivity made with a variable-head permeameter by Gonthier and others (1974) in coarse-grained deposits in the lower Pawcatuck River Basin ranged from 0.7 to $2.7 \mathrm{ft} / \mathrm{d}$. In an adjacent basin, Rosenshein and others (1968) reported an average value of $2.3 \mathrm{ft} / \mathrm{d}$ for coarse-grained bed materials using this same field method. Parameter SB_K was specified a value of $3 \mathrm{ft} / \mathrm{d}$.

Four remaining parameters representing horizontal hydraulic conductivity of glacial deposits (K_SAND, K_S\&G, K_MOR and K_TILL) were not highly correlated (parameter correlation coefficients greater than 0.95 ). Thus these four parameters were estimated by nonlinear regression.

The quality of model calibration can be determined by analysis of the weighted residuals, both numerically and graphically, and by the reasonableness of optimal parameter values and their associated confidence intervals; Hill and Tiedeman (2007) describe this analysis in detail. Weighted residuals should be randomly distributed and close to zero. The average weighted residual was $0.15 \mathrm{ft}$ for all groundwaterlevel and base-flow observations and it ranged from a minimum of $-12.34 \mathrm{ft}$ to a maximum of $12.33 \mathrm{ft}$. The sum of squared weighted residuals was 2,184 for the calibrated model. The calculated error variance (sum of squared weighted residuals divided by the difference between the number of observations and the number of parameters estimated by nonlinear regression) was 22.8 , and the standard error of the regression (square root of the calculated error variance) was 4.77. Although these measures of the overall magnitude of the weighted residuals should, theoretically, equal 1 , that is not commonly the case for groundwater models (Hill and Tiedeman, 2007).

Weighted residuals for base flows and for groundwater levels are shown graphically in figure 8 , which symbolizes the weighted head residuals by the category of their groundwaterlevel observation group. A comparison of weighted observed values and weighted simulated values (fig. $8 A$ ) indicated a good agreement; the correlation between them was 0.99 . Figure $8 B$ shows that weighted residuals are generally randomly distributed around zero for all weighted simulated values. Furthermore 94 percent of the weighted residuals are within two standard errors of the regression.

The spatial distribution of weighted base flow and groundwater-level residuals is shown in figure 9. Unweighted residuals for groundwater levels would be one-half of the weighted residuals for observations in the valley-fill and double the weighted residuals for observations in the uplands. Weighted residuals are generally distributed randomly throughout most of the modeled area.

The two net base-flow gain observations between partialrecord and continuous streamgages on the Chipuxet River and Chickasheen Brook compare favorably with simulated values. The values of simulated net base flow gain for the Chipuxet River $\left(8.23 \mathrm{ft}^{3} / \mathrm{s}\right)$ and for Chickasheen Brook $\left(1.90 \mathrm{ft}^{3} / \mathrm{s}\right)$ were close to observed values of 8.60 and $2.58 \mathrm{ft}^{3} / \mathrm{s}$, respectively. 

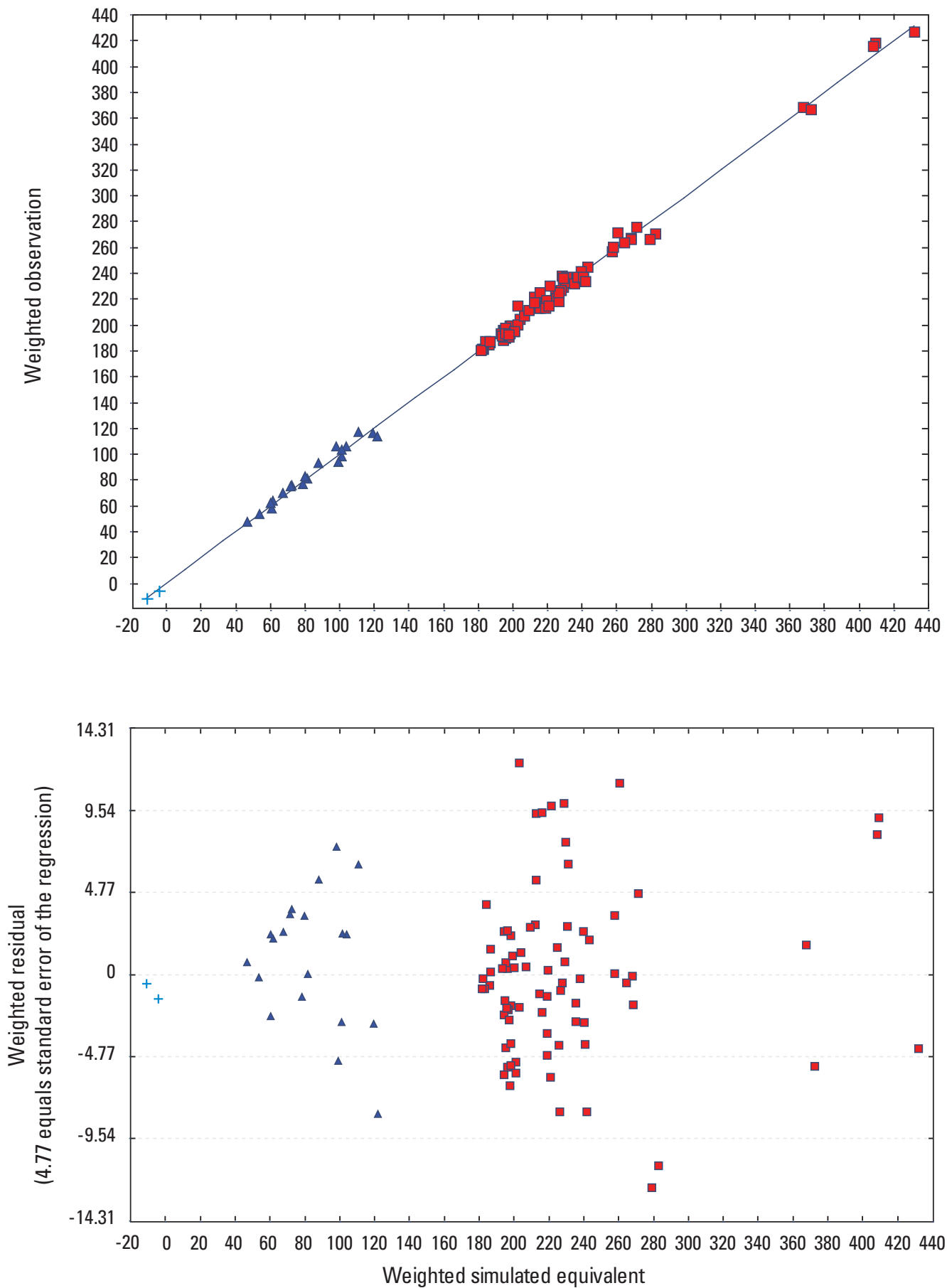

EXPLANATION

Groundwater-level observation

- Group A

$\Delta$ Group B

+ Streamflow observation

Figure 8. Relation of $A$, weighted observation to weighted simulated equivalent and $B$, weighted residual to weighted simulated equivalent, Chipuxet River and Chickasheen Brook Basins, Rhode Island. 


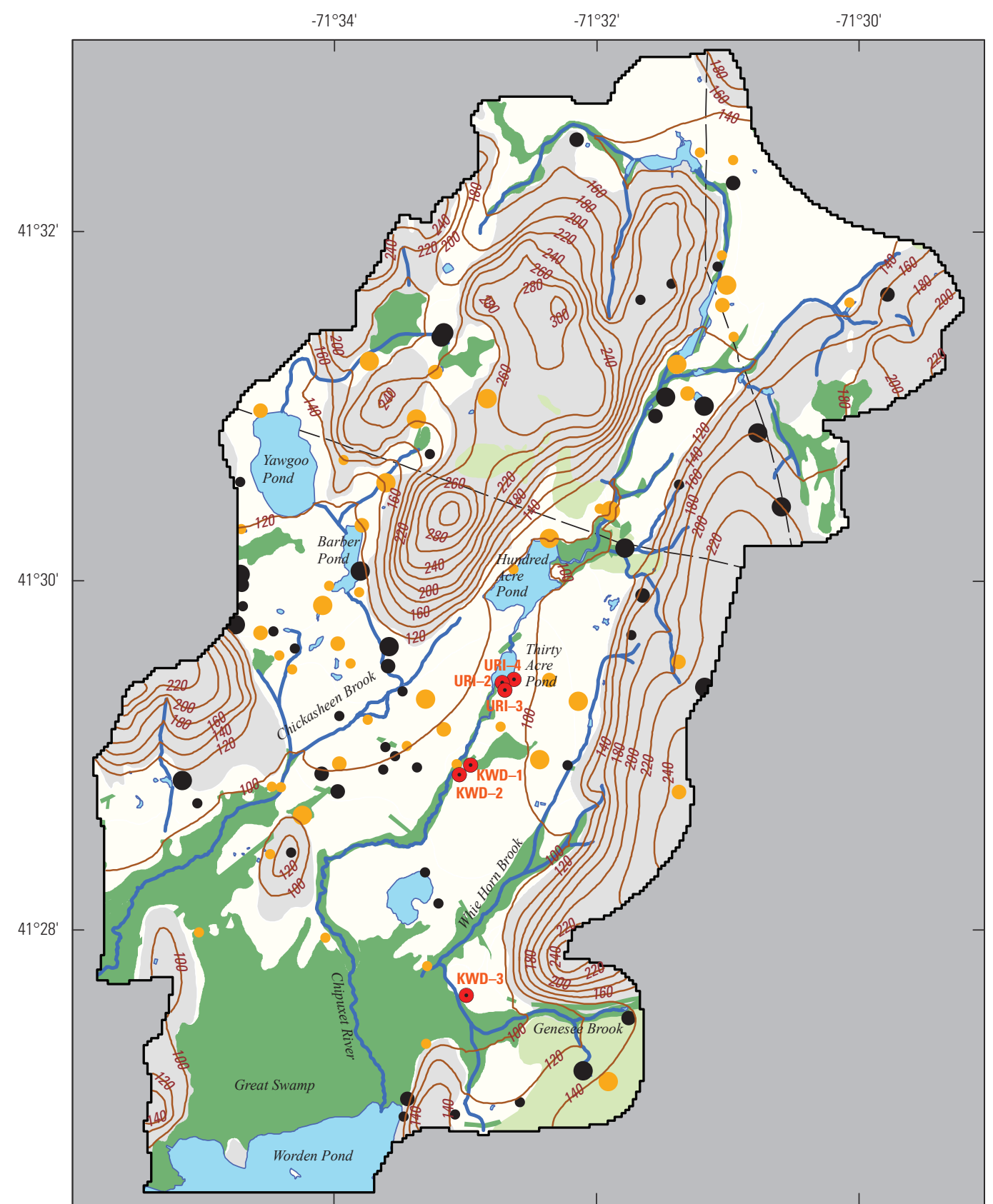

Base from U.S. Geological Survey 1:24,000 topographic maps, 1995 and 2001 Rhode Island State plane projection North American Datum of 1983
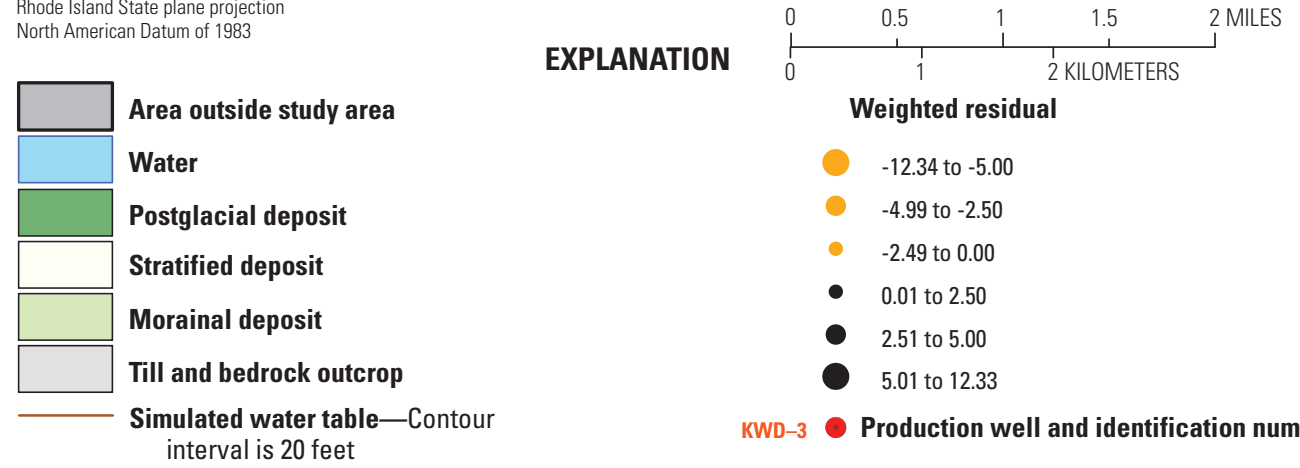

KWD-3 Production well and identification number

Figure 9. Spatial distribution of weighted residuals and simulated water-table contours for calibrated, steady-state conditions in the Chipuxet River and Chickasheen Brook Basins, Rhode Island. Unweighted residuals for groundwater levels would be one-half the weighted residuals for observations in the valley-fill areas and double for observations in the uplands. 
In addition, simulated base flow for the continuous streamgage on the Chipuxet River $\left(18.6 \mathrm{ft}^{3} / \mathrm{s}\right)$ was within 5 percent of the observed base flow of $19.5 \mathrm{ft}^{3} / \mathrm{s}$.

Optimal values for the four horizontal hydraulic parameters (K_SAND, K_S\&G, K_MOR, and K_TILL) that were estimated using nonlinear regression are listed in table 2. The optimal values are within a plausible range of values, although the value for K_S\&G $(99.3 \mathrm{ft} / \mathrm{d})$ was lower than that for K_SAND $(155 \mathrm{ft} / \mathrm{d})$. The majority of the saturated sand and gravel deposits is along the valley edges, in the upper part of the Chickasheen Brook Basin, and at depth in the central part of the valley in the Chipuxet River Basin. Along the valley edges and in the upper Chickasheen Brook Basin, areas of thin stratified deposits might overlie proportionately large quantities of till; this configuration would lower the overall transmissivity. In addition, few data were available to define the bedrock surface accurately in some areas, especially along the valley edges where the bedrock-surface altitude varied substantially. Also, these deposits were laid down near the ice margin and might not be well sorted. In the Chipuxet River Basin, most saturated sand and gravel deposits at depth lacked groundwater-level observations for calibration. Finally, the 95-percent confidence intervals determined by nonlinear regression for K_S\&G and K_SAND overlapped (table 2).

Few data from the literature are available for hydraulic properties of morainal deposits. Because morainal deposits in southern Rhode Island are composed of a mix of sandy till and stratified deposits, bulk hydraulic properties most likely lie between properties of these two materials. Laboratory measurements indicated that hydraulic conductivity properties for morainal deposits in the upper Pawcatuck River Basin range from 0.1 to $13 \mathrm{ft} / \mathrm{d}$ (Allen and others, 1966). Values determined by manual calibration and nonlinear regression of groundwater-flow models ranged from 5 to $70 \mathrm{ft} / \mathrm{d}$ (Friesz, 2004, 2010; Masterson and others, 2007). The optimal value for parameter K_MOR, $36.9 \mathrm{ft} / \mathrm{d}$, lies within this range.

The uncertainty of the parameter estimate is indicated by the 95 -percent linear confidence interval for each optimal value (table 2). For these linear confidence intervals to be valid, weighted residuals should be normally distributed, and the model linear near the estimated optimal values (Hill and Tiedeman, 2007). If weighted residuals are independent and normally distributed, then they plot on an approximately straight line on a normal probability graph (fig. 10). The correlation between weighted residuals and the normal order statistics for the calibrated model was 0.982 . This value is greater than the critical value for 100 observations, 0.976 , at the 5-percent significance level, which indicates that the weighted residuals are independent and normally distributed. The degree of model linearity can be quantified using the modified Beale's measure, calculated with the ModelLinearity program (Poeter and others, 2005). The model is considered effectively linear if the modified Beale's measure is less than 0.036 and nonlinear if it is more than 0.40 . The modified Beale's measure for the model was 0.073 , indicating that the model is moderately linear. The confidence intervals listed in table 2 are thus approximate values.

The 95-percent confidence intervals for the parameter estimates are all within the ranges of reasonable values reported in the literature. A comparison of the relative precision of different parameter estimates can be made using the coefficient of variation (standard deviation of the estimated value divided by the optimal value; table 2); a smaller coefficient of variance indicates a more precisely estimated value for the parameter. The coefficient of variations ranged from 0.15 to 0.26 . Horizontal hydraulic conductivity parameter K_MOR was the most precisely estimated, whereas the horizontal hydraulic conductivity parameter K_SAND was the least precisely estimated. The order of the most to least precisely estimated parameter values follows the same order as that of the parameter sensitivities (fig. 7) because of the information provided by the observations in the regression.

The analysis of the weighted residuals and optimal parameter values indicated that the groundwater model is acceptable for the purposes of the study. Model-fit statistics indicated that simulated values for groundwater levels and for base flows are generally close to observed values. Optimal parameter values are realistic, and their confidence intervals include reasonable values.

\section{Simulated Water Table and Water Budget}

The altitude and configuration of the simulated water table for the steady-state calibrated model, shown in figure 9 at $20-\mathrm{ft}$ contour intervals, are consistent with the conceptual model of groundwater flow in the study area and with regional groundwater contours (Allen and others, 1966; Masterson, $2011)$ as well as with groundwater maps on a quadrangle scale by Bierschenk (1956) and Hahn (1959). Groundwater generally flows from topographically high areas and discharges to streams and surface-water bodies. In the uplands, the simulated water table approximately parallels the land surface, and simulated groundwater divides generally coincide with watershed divides. The water table gradient is steepest in the till uplands and in valley-fill deposits near the contact and then it flattens in the more transmissive valley-fill areas of stratified deposits and wetlands.

The simulated groundwater budget for the calibrated model indicated that recharge from direct precipitation provides $44.5 \mathrm{ft}^{3} / \mathrm{s}$, which constitutes 93 percent of the inflow. Streamflow loss accounts for the remaining inflow, $3.3 \mathrm{ft}^{3} / \mathrm{s}$ (7 percent). Most of this streamflow loss occurs from tributaries downstream of the upland-valley contact, which are near areas of abrupt changes in transmissivity, and at the downstream ends of ponds. Of the total inflow, $46.4 \mathrm{ft}^{3} / \mathrm{s}$ (97 percent) of the groundwater discharges to streams, and $1.3 \mathrm{ft}^{3} / \mathrm{s}$ ( 3 percent) is withdrawn by KWD and URI production wells. 


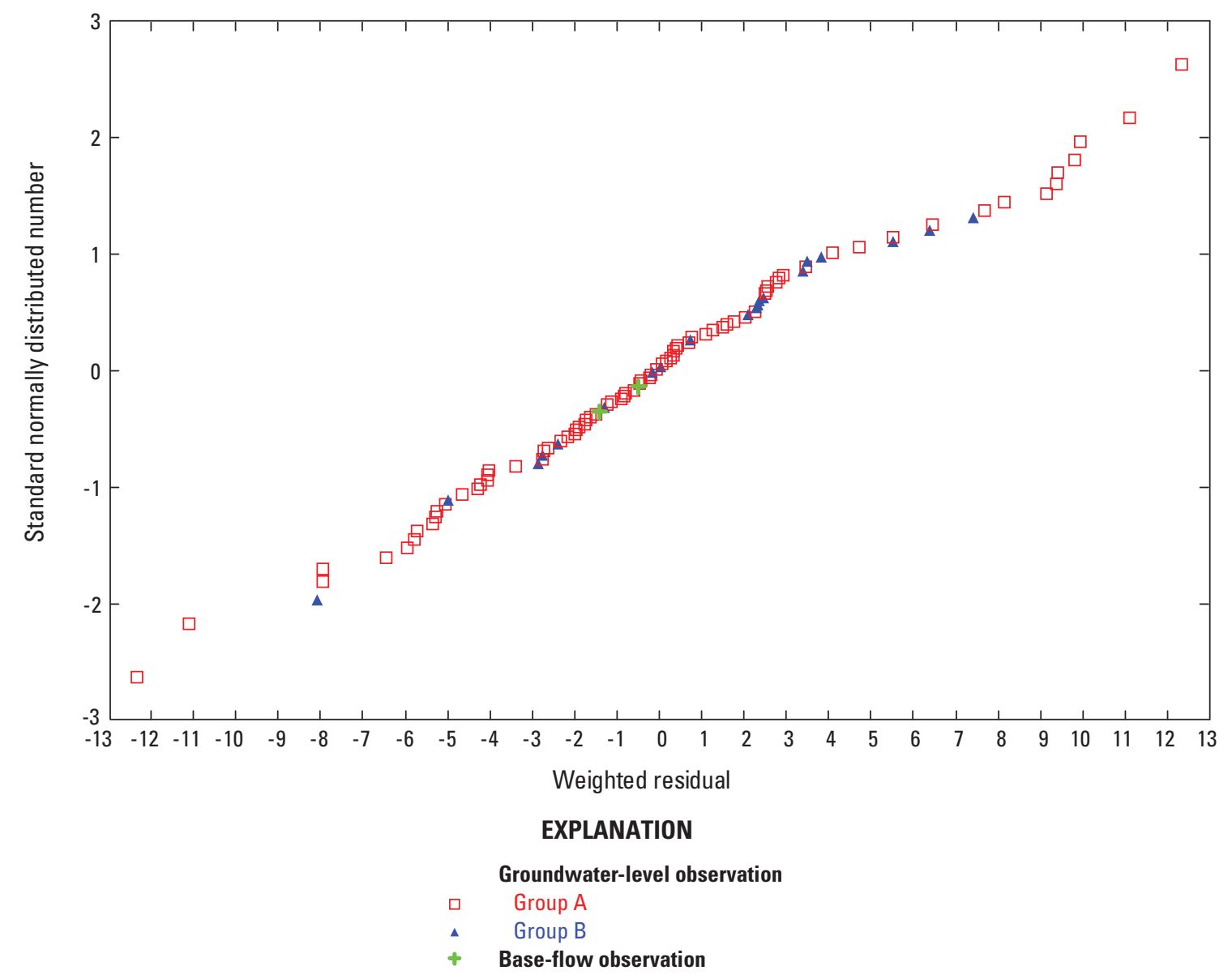

Figure 10. Normal probability of the weighted residuals, Chipuxet River and Chickasheen Brook Basins, Rhode Island.

\section{Transient Model}

The transient model was developed to simulate the average annual hydrologic cycle in the study area. Average annual hydrologic conditions are defined as the average conditions during each of the 12 months of a 30 -year period. The purpose of simulating transient conditions was to examine long-term trends in the hydrologic system due to climate change. The analysis of the effects of climate change on the groundwater system was done by comparing projected average monthly conditions for 30 -year periods in the 21 st century with a 30 -year period in the historical period by using the calibrated transient model.

The transient model was calibrated to monthly averages from 1974 through 2003. The transient model used the same hydraulic property values and the same type of boundary conditions as the steady-state model. However, an additional hydraulic property, storage, was required for the transient simulation. The transient model was manually calibrated to groundwater levels and base flow by adjusting storage values.

\section{Time Discretization and Initial Conditions}

The annual hydrologic cycle was divided into 12 monthly stress periods; the length of each stress period was the number of days in the month. Each stress period was subdivided into 14 time steps. Groundwater levels and base flow simulated by the calibrated steady-state model were used as initial conditions for the transient simulation. The total transient simulation was five annual cycles (60 stress periods) to ensure that enough time had elapsed in the simulation to achieve dynamic equilibrium, a condition in which simulated water levels and base flows do not change on an annual basis. The final year of the simulation (12 monthly stress periods) was used to represent hydrologic conditions over an average year.

\section{Recharge Rates and Water Withdrawals}

Recharge rates to the sediments and ponds varied monthly. Spatially distributed monthly recharge rates to the sediments determined by the calibrated SWB model for the 
study area from 1974 through 2003 were averaged by model cell to determine rates for the 12 months of the year. During this 30 -year period, average monthly recharge rates to the sediments over the entire study area ranged from 0.2 in. in July to 4.5 in. in March.

Monthly recharge rates to ponds were calculated by subtracting average monthly free-water-surface evaporation rates from average monthly precipitation rates measured from 1974 through 2003. Total evaporation for the growing season from May through October was estimated to be $22 \mathrm{in} / \mathrm{yr}$ for southern Rhode Island (Farnsworth and others, 1982). The total annual evaporation of 29 in. (Farnsworth and others, 1982) results in 7 in. of evaporation for the dormant season from November through April. Assuming monthly evaporation rates are constant during these two periods (growing and dormant seasons), average monthly evaporation rates were 3.67 in. from May through October and 1.17 in. from November through April. Monthly recharge rates to ponds ranged from -0.5 in. in July to $3.8 \mathrm{in}$. in March.

Monthly withdrawal rates at the KWD and URI production wells were set equal to the average monthly withdrawal rates for each well from 2000 through 2003. It was assumed that this 4-year period adequately represented the 30-year period average monthly withdrawals for calibration purposes. Average monthly withdrawals for the three production wells that were used during this period (KWD-1, KWD-2, and URI-4) ranged from $505 \mathrm{gal} / \mathrm{min}$ in January to $634 \mathrm{gal} / \mathrm{min}$ in September.

\section{Storage Properties}

Storage in confined layers (specific storage) is due to the compression and expansion of the water and sediments. In an unconfined layer, in addition to the compression and expansion, storage is predominately due to water draining from or filling the pores at the water table (specific yield; Lohman, 1979). Storage values specified in the transient model were based on values reported in the literature. For stratified deposits and till deposits, the predominate sediments in the study area, specific yield values were manually calibrated within the range of these reported values.

The specific yield of unconfined aquifers is in the range of 0.01 to 0.3 (Freeze and Cherry, 1979). Specific yield values of stratified deposits determined from aquifer-pump tests in the Chipuxet River Basin ranged from 0.13 to 0.27 and averaged 0.18 (Johnston and Dickerman, 1985). The final calibrated value for stratified deposits was 0.18 . This specific yield value was also used for morainal deposits, pond-bottom sediments, and highly decomposed peat.

Specific yield of till in the upper Pawcatuck River Basin based on laboratory analysis of till deposits ranged from 0.04 to 0.22 and averaged 0.11 (Allen and others, 1963). Laboratory determinations of specific yield of disturbed samples, however, are likely to be greater than those obtained from field measurements (Lohman, 1979). The final calibrated value for till deposits was 0.05 .
For specific yield of bedrock, Gburek and others (1999) reported values of 0.0001 for poorly fractured rock, 0.001 for moderately fractured rock, and 0.005 for highly fractured rock. Lyford and others (2003) calculated a storage value for bedrock from an aquifer-pump test in Massachusetts that was close to the value for moderately fractured rock. The specific yield value for moderately fractured rock was used in this study. Poorly decomposed wetland deposits were assigned a specific yield value of 0.5 based on values reported in Verry and Boelter (1979), and ponds were assigned a value of 1 . Finally, a specific storage value of 0.00001 per foot $\left(\mathrm{ft}^{-1}\right)$ determined by Moench and others (2000) for Cape Cod sediments was specified for model layers beneath the highest active layer for all lithologic units.

\section{Calibration}

The transient model was calibrated by comparing simulated values to average monthly water levels at long-term network well SNW6 and to average monthly base flow at the Chipuxet River streamgage (01117350) from 1974 through 2003. In the uplands, a qualitative comparison of simulated to observed groundwater levels was done. Observation well EXW278 (fig. 1) is screened in till deposits and completed at the top of the bedrock surface. Only 13 years of water levels at this well were available for the 30 -year period. In addition, for several years during fall, water levels were below the bottom of the well. Hahn (1959) reported that about 20 percent of the till wells in the study area went dry in some years. An approximate comparison of simulated to observed water levels at EXW278 and of the percentage of the areal extent of till that went dry during the transient simulation was also done as part of the model calibration. For the transient model no model-fit statistic was used in the calibration.

The model was calibrated by varying specific yield of the stratified and till deposits within reasonable values. The range in annual groundwater-level and base-flow fluctuations decreased with increasing specific yield; decreasing specific yield caused the opposite effect. The final storage values used in the calibrated model slightly overestimated the annual magnitude of water levels and underestimated the annual magnitude of base flows in comparison to observed values at well SNW6 and the Chipuxet River streamgage.

Simulated and observed hydrographs from data measured at observation well SNW6 are shown in figure 11A. Simulated groundwater levels are at a higher altitude compared with observed groundwater levels by 2 to $3 \mathrm{ft}$, as was the case for the steady-state calibration because of model error. Most of the difference in the absolute heads between simulated and observed groundwater levels was probably because of the difference in the accuracy of the altitude of the measuring point of the observation well and of the simulated streambeds, which help determine nearby groundwater altitudes. Seasonal fluctuation as shown on the hydrograph of simulated water levels, however, is similar to the fluctuation shown in the hydrograph of observed water levels, although the lowest 


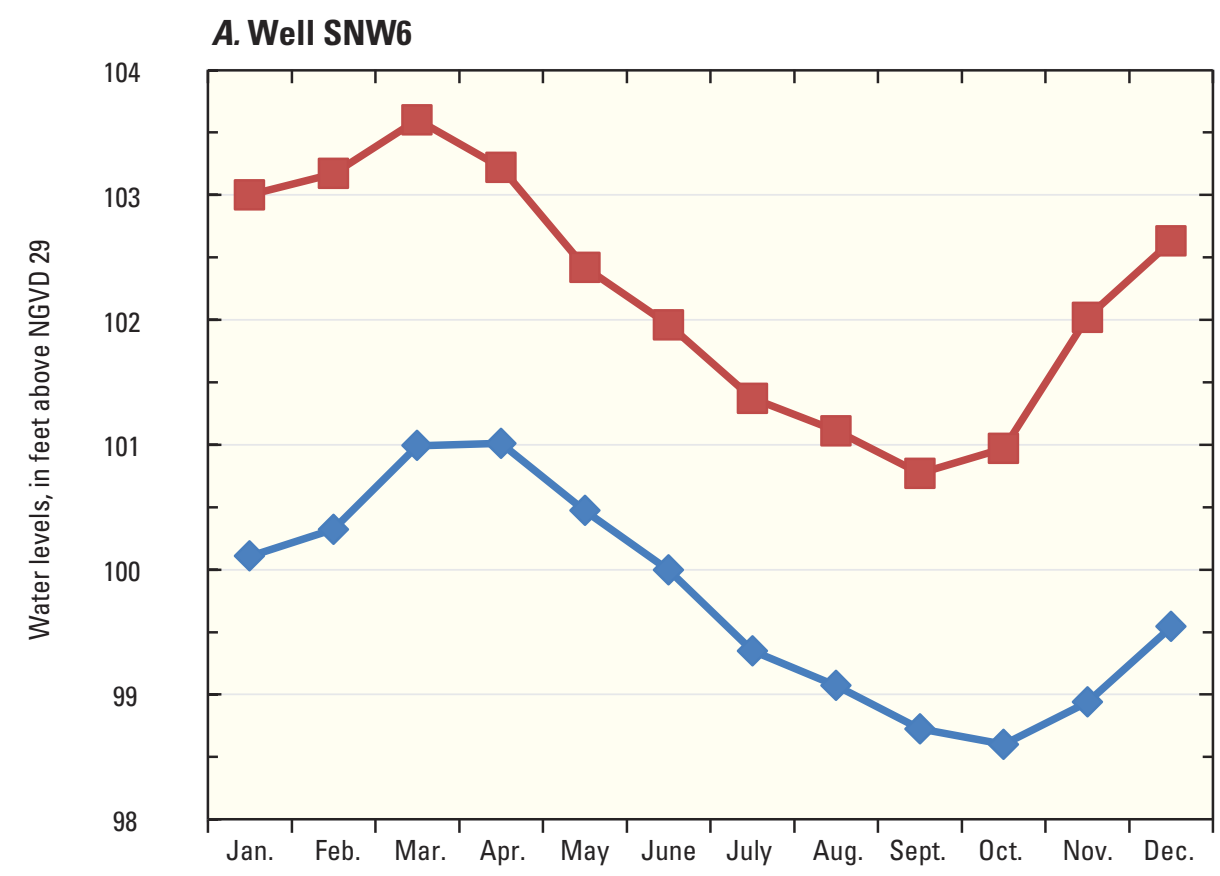

EXPLANATION

Observed

\section{B. Chipuxet River streamgage}

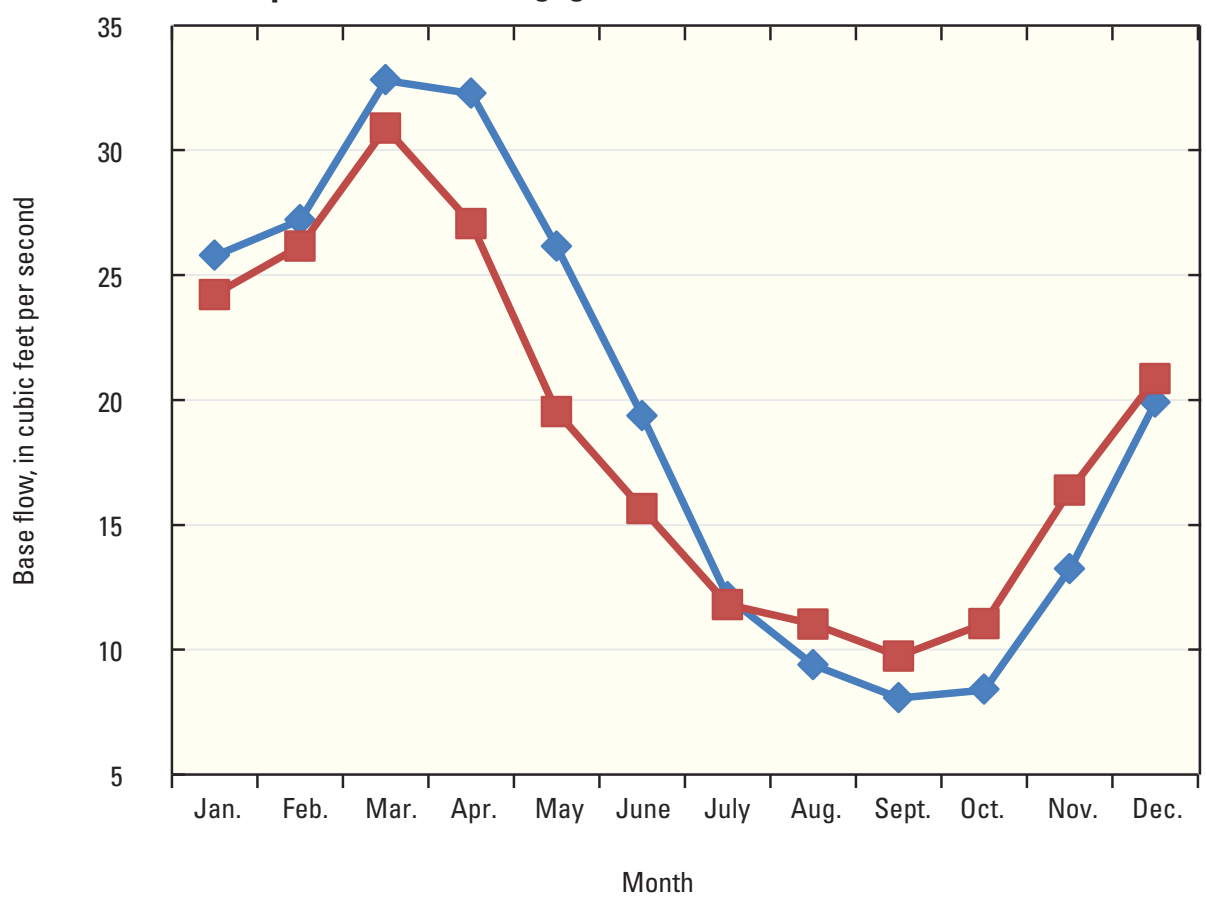

Figure 11. Average monthly observed and simulated $A$, water-level altitudes at observation well SNW6 and $B$, base flow at the Chipuxet River streamgage in the Chipuxet River and Chickasheen Brook Basins, Rhode Island. 
simulated groundwater level is in September compared with the lowest observed groundwater level, which is in October. The magnitude in annual fluctuation compares favorably with the $2.83 \mathrm{ft}$ for the hydrograph of simulated water levels and $2.41 \mathrm{ft}$ for the hydrograph of observed water levels. This comparison indicates that the transient model adequately simulates the timing of seasonal groundwater-level fluctuations over an average annual hydrologic cycle.

Average monthly simulated and observed base flows at the Chipuxet River streamgage are shown in figure $11 B$. In both cases, the maximum base flow is in March and the minimum base flow is in September. Simulated maximum and minimum base flows are 30.9 and $9.7 \mathrm{ft}^{3} / \mathrm{s}$, respectively, which are close to the observed maximum and minimum average monthly base flows of 32.8 and $8.1 \mathrm{ft}^{3} / \mathrm{s}$, respectively. Thus the data indicate that the transient model reasonably represents the magnitude and timing of base flow variations in an average year.

\section{Simulation of Areas Contributing Recharge and Prediction Uncertainty Analysis}

Calibration of the steady-state groundwater-flow model by inverse modeling by using nonlinear regression provided an optimal set of parameter values. This optimal parameter set was estimated by minimizing the weighted residuals between the observation dataset ( 98 groundwater levels and 2 base flows) and simulated values. A predicted area contributing recharge to a production well in the modeled area based on this optimal parameter set provides a single, most likely contributing area (deterministic contributing area). The parameter values, however, were estimated with different levels of uncertainty; this uncertainty in the optimal values was based on the information that the observation dataset provided on the parameters. Parameter uncertainty and its associated effects on model predictions (spatial variability of the simulated contributing area to a well) can be evaluated by a stochastic Monte Carlo analysis. The parameter variance-covariance matrix from nonlinear regression can be used to create plausible parameter sets for the Monte Carlo analysis (Starn and others, 2010). The parameter variance-covariance matrix incorporates the uncertainty of the parameter estimates and the correlation among parameters from the calibrated model. The Monte Carlo analysis was done by replacing the parameter set in the calibrated model by a plausible parameter set multiple times. The probability of a particular location being in the contributing area to a production well was calculated from these multiple model simulations.

Areas contributing recharge were determined for the production wells based on their 2007 through 2011 average withdrawal rate and their maximum pumping rate (table 1). From 2007 through 2011, four of the six production wells were pumped (KWD-1, KWD-2, KWD-3, and URI-4). However, one of the four production wells that was pumped, KWD-1, had a very low average withdrawal rate (5 gal $/ \mathrm{min}$ ). At this low withdrawal rate, only a part of the water that flows into the model cell with the well screen is removed by the production well (weak sink). Because it cannot be determined whether water that enters this cell is withdrawn or continues through the groundwater system, the contributing area to the production well was not shown.

The total maximum pumping rate for the production wells, $3,700 \mathrm{gal} / \mathrm{min}\left(8.24 \mathrm{ft}^{3} / \mathrm{s}\right)$, is 6.4 times greater than the 2007 through 2011 average pumping rate of $583 \mathrm{gal} /$ $\min \left(1.30 \mathrm{ft}^{3} / \mathrm{s}\right)$. The maximum pumping rate for the production wells represents the maximum-rated capacity of the well pumps. Maximum pumping rates used in the model simulation are not proposed, long-term (continuous) withdrawal rates. Instead, RIDOH considers the simulated areas contributing recharge at these maximum rates only when implementing land-use planning to protect the quality of the water that the production wells supply. Average withdrawals might change because of changes in water usage or changes in State policies. Areas contributing recharge for the maximum pumping rate therefore represent conservative, or larger, areas for land-use planning than if lower pumping rates were to be used.

\section{Deterministic Areas Contributing Recharge}

Simulated deterministic areas contributing recharge and simulated groundwater traveltimes to the production wells were determined on the basis of the calibrated steady-state model for simulated pumping conditions and by use of the particle tracking program MODPATH (Pollock, 1994). The particle tracking program calculates groundwater-flow paths and traveltimes on the basis of the head distribution computed by the groundwater-flow simulation. Areas contributing recharge were delineated by forward tracking of particles from recharge locations to the discharging wells. One particle for each model cell was used, thus each particle represents a surface area of $125 \mathrm{ft}$ by $125 \mathrm{ft}$.

RIDOH and RIDEM assess the vulnerability of drinking water to contamination, in part, by land uses. The size of the simulated areas contributing recharge to the production wells for the average pumping rates from 2007 through 2011 (wells KWD-2, KWD-3, and URI-4) covered a total area of $0.63 \mathrm{mi}^{2}$ (fig. 12) and the size of the areas contributing recharge for the maximum-rated pumping capacity for all production wells covered a total area of $2.55 \mathrm{mi}^{2}$ (fig. 13). Land cover in the areas contributing recharge to the wells near the Chipuxet River includes substantial amount of urban and agricultural land uses (fig. 2). Land cover in the areas contributing recharge to production well KWD-3, which is near Genesee Brook, is less developed but small areas of agriculture, residential, and sand and gravel mining are also in this contributing area. 


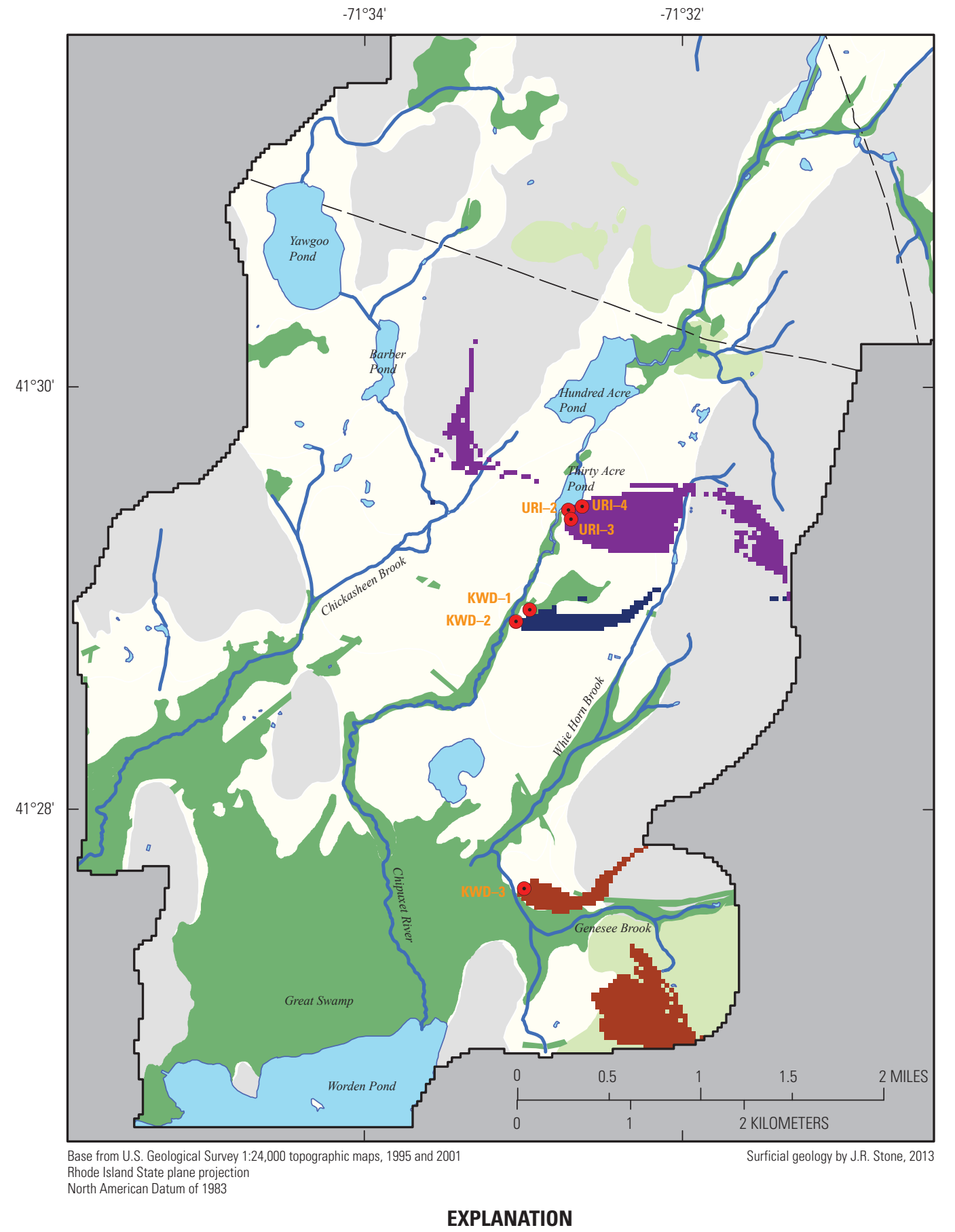

\begin{tabular}{|l|l}
\hline & Area outside study area \\
\hline & Water \\
\hline & Postglacial deposit \\
\hline & Stratified deposit \\
\hline & Morainal deposit \\
\hline & Till and bedrock outcrop
\end{tabular}

Simulated deterministic areas contributing recharge

KWD-2

KWD-3

URI-4

KWD-3 Production well and identification number

Figure 12. Simulated areas contributing recharge to the production wells at their average pumping rates from 2007 through 2011 in the Chipuxet River and Chickasheen Brook Basins, Rhode Island. 


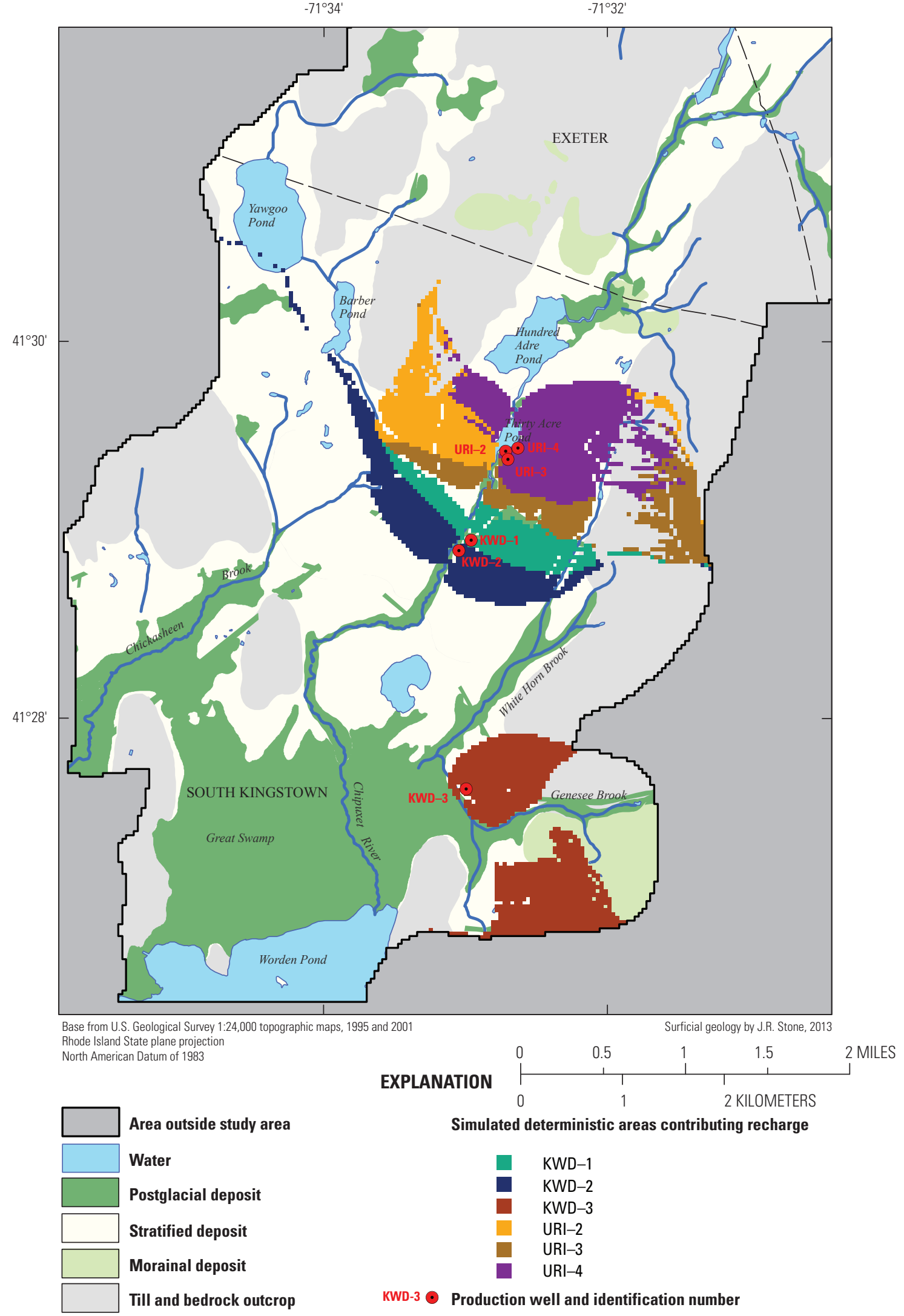

Figure 13. Simulated areas contributing recharge to the production wells at their maximum pumping rates in the Chipuxet River and Chickasheen Brook Basins, Rhode Island. 
Most simulated areas contributing recharge for both pumping rate scenarios extend upgradient from the production wells to groundwater divides and topographical divides, some of which serve as model boundaries. Areas contributing recharge extend beneath and beyond streams and include morainal and upland till deposits. Some contributing areas include isolated areas remote from the well, including small areas the size of a model cell. For example, the contributing area to well KWD-3 for both average and maximum withdrawal rates includes an isolated area in morainal and stratified deposits on the opposite side of Genesee Brook from the well. Particle tracks showed that recharging water originating in these morainal and stratified deposits travels along deep groundwater-flow paths and, under pumping conditions, passes beneath Genesee Brook to well KWD-3. Recharging water between this contributing area and Genesee Brook travels along shallow and intermediate depth flow paths before it discharges to the brook.

The location and shape of the areas contributing recharge to an individual well at the maximum pumping rates are strongly affected by nearby pumping wells and associated withdrawal rates. Wells URI-2 and URI-3 are overlain by the contributing area to well URI-4. Wells URI-2 and URI-3 are screened deeper in the aquifer than well URI-4 (fig. 3), and recharge in the vicinity of these two wells travels along groundwater-flow paths above and around their screened interval. The contributing area to well URI-2 is mostly on the opposite side of the Chipuxet River from the well, and for well URI-3, that part of the contributing area in the valley-fill deposits is south, or downvalley of the well. For four of the five wells adjacent to the Chipuxet River (URI wells and KWD-1), the lateral extent of the contributing areas are generally constrained by groundwater divides in the uplands bordering the valley. The contributing area to well KWD-2, however, which is shifted downvalley compared with its contributing area for the average pumping rates, extends a large distance northwestward from the well along the Chickasheen Brook valley to Yawgoo Pond. At these large simulated pumping rates, surface-water infiltration also contributes water to the wells and affects the sizes of the contributing areas. The wells along the Chipuxet River derive part of their water from the river, Chickasheen Brook, and White Horn Brook, and well KWD-3 derives part of its water from Genesee Brook. Because surface water is a source of water to the wells at these large simulated pumping rates, the quality of surface water could affect the quality of water withdrawn by the wells.

Simulated traveltime estimates from recharging locations to the production wells for the maximum pumping rate are shown in figure 14 . Porosity values were specified in the model for MODPATH, but they affect only groundwater velocity and do not change the contributing areas to the wells. Stratified deposits were assigned a porosity of 0.35 based on values determined for similar deposits in the upper
Pawcatuck River Basin (Allen and others, 1963) and Cape Cod, Massachusetts (Garabedian and others, 1991). A porosity of 0.35 was specified for till deposits based on a range of values (0.22-0.50) determined for till deposits in the upper Pawcatuck River Basin (Allen and others, 1963) and southern New England (Melvin and others, 1992). Morainal deposits were also assigned a porosity value of 0.35 . Wetland deposits were assigned a value of 0.8 (Verry and Boelter, 1979). For bedrock, a porosity of 0.02 was assigned based on values for crystalline rock summarized in Meinzer (1923). Porosity for pond water was set at 1 .

Traveltimes generally depend on where recharge enters the aquifer in relation to the production well. Water that recharges the aquifer near the wells has the shortest traveltimes and youngest water, whereas water originating in the till uplands, the morainal deposits, and the Chickasheen Brook valley has the longest traveltimes and the oldest water. Traveltimes ranged from less than 1 year to more than 200 years. The median traveltime for all six wells ranged from 3.5 to 8.6 years. A comparison of median traveltimes between maximum and average pumping rates for wells KWD-2, KWD-3, and URI-4 indicated that increased pumping caused the percentage of young water to increase for all three wells. Areas contributing water to the wells where traveltimes were 10 years or less ranged from 57 to 91 percent for the maximum pumping rate. These percentages for traveltimes 10 years or less and the relatively short median traveltimes indicate that the wells are vulnerable to contamination from activities on the land surface.

\section{Probabilistic Areas Contributing Recharge}

The effects of parameter uncertainty on model predictions (the predicted contributing area) were quantitatively measured by a Monte Carlo analysis. A Monte Carlo analysis was used to obtain the probability of a recharge location being in the contributing area of a well or well center. The probability distribution is related to the information that the observation dataset provided on the estimated parameters, to prior information on specified parameters, and to the sensitivity of the simulated contributing area to the parameters. Hundreds of parameter sets generated from summary statistics of the calibrated steady-state model were used to run hundreds of model simulations in the Monte Carlo analysis. Because combinations of reasonable parameter values might result in unrealistic groundwater levels and streamflows, the parameter sets were evaluated using the pumping rates and associated observation dataset from the calibrated model. Those parameter sets that simulated realistic results were then used in Monte Carlo analyses for the two pumping scenarios.

Parameter values for the Monte Carlo analysis were created by the following equation (Starn and others, 2010; Starn and Bagtzoglou, 2012): 


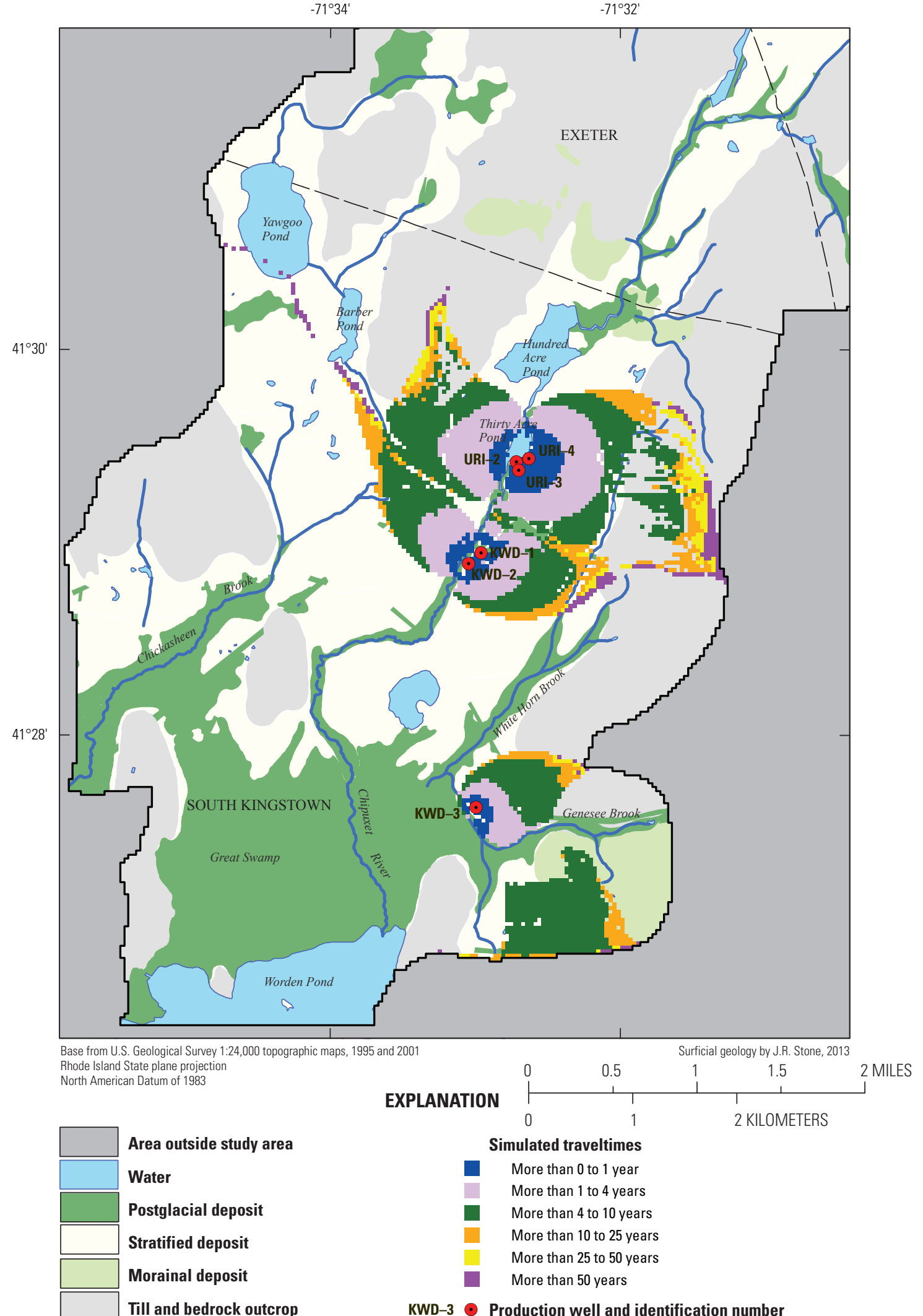

Figure 14. Simulated groundwater traveltimes to the production wells at their maximum pumping rates in the Chipuxet River and Chickasheen Brook Basins, Rhode Island. 


$$
b=z \sigma+\mu
$$

where

$b \quad$ is a set of parameter values,

$z \quad$ is a vector of normally distributed random numbers with a mean of 0 and standard deviation of 1 ,

$\sigma \quad$ is the square root of the variance-covariance matrix calculated using Cholesky decomposition, and

$\mu \quad$ is a vector of optimal parameter values.

Parameter values that could not be estimated by nonlinear regression and thus were not included in the parameter variance-covariance matrix of the calibrated model might still be important for model predictions (for this study the size, shape, and location of the area contributing recharge to the production wells). The remaining three glacial hydraulic parameters (K_FINE, K_TKTILL, and KV_SURF) and two postglacial hydraulic parameters (KV_PDPT and SB_K) were therefore incorporated into the parameter variance-covariance matrix using the specified parameter values. The parameter representing recharge rates on surficial deposits (R_MULT), although calculated by the SWB model and calibrated to a long-term streamgage, was also included in the parameter variancecovariance matrix. Groundwater discharge at the streamgage represents the bulk recharge rate and not individual recharge rates for specific soil types or land uses. In addition, there is uncertainty in the size of the groundwater contributing area to the streamgage. Mean annual base flow from six USGS long-term streamgages in southern Rhode Island ranged from 22.5 to $28.1 \mathrm{in} / \mathrm{yr}$ over their basins (Dickerman and others, 1997; Friesz, 2012). The average of the mean annual base flow for the six streamgages was $25 \mathrm{in} / \mathrm{yr}$, which is the same value as the mean annual recharge rate calculated by the SWB model averaged over the study area. Parameters that represent bedrock (K_ROCK and KV_ROCK), pond water (K_SW and R_SW), and the poorly decomposed peat at the top of the wetland (K_WETLD) were not changed in this analysis. Incorporating these six parameters (K_FINE, K_TKTILL, KV_SURF, KV_PDPT, SB_K, and R_MULT) into the parameter variance-covariance matrix, however, caused large unrealistic uncertainties around the specified parameter values because the information that observations provided was insufficient. Prior information on these parameters from the literature (see "Boundary Conditions" and "Hydraulic Properties" sections) was used to constrain this uncertainty (table 2). Prior weight for R_MULT was estimated to be \pm 15 percent around the specified value of 1 .

The addition of these six parameters (K_FINE, $\mathrm{K}$ TKTILL, KV_SURF, KV_PDPT, SB_K, and R_MULT) into the parameter variance-covariance matrix incorporated into the Monte Carlo analysis all parameter uncertainty potentially important for model predictions. Parameter uncertainties are from the observation dataset, but also from prior information on parameters that the modeler provided.
Parameter sets created by equation 1 are shown in figure $15 \mathrm{~A}$. The hydraulic parameters were log-transformed in the model. The parameter sets have a lognormal or normal distribution around the optimal or specified parameter value; the spread of these data indicates the certainty with which each parameter was estimated, considering the available observations and prior information. Parameters incorporated into the variance-covariance matrix using prior information have the least certainty, which would be expected because a prior weight was used so as to incorporate most plausible values. Parameter sets, however, with glacial anisotropies less than 1 (horizontal hydraulic conductivity less than vertical hydraulic conductivity) or more than 100 were removed (conditioned) from the parameter sets because they were considered unrealistic for the aquifer as a whole.

For the Monte Carlo analysis, the model was first run with 500 parameter sets and with the average pumping rates from 1995 through 2003 used in calibrating the model. The 10 hydraulic and recharge parameter values in each dataset replaced the corresponding parameter values in the calibrated model. Three criteria for accepting a given parameter set were used: (1) the model converged, (2) the model mass balance was 1 percent or less, and (3) a model-fit statistic (calculated error variance) was less than a specified value. The third acceptance criterion was used so that model-prediction uncertainty would not be overestimated by using a parameter set that produced unrealistic groundwater levels or streamflows compared with that for the calibrated model. The value used for this criterion, however, can be model dependent and subjective. For this model application of the Monte Carlo analysis, a calculated error variance of 90 was selected for the third criterion, or about four times the calculated error variance of the calibrated model. Of the 500 parameter sets run with MODFLOW, 484 sets (97 percent) converged and had a water budget of 1 percent or less, and of these, 467 sets (93 percent of the total) had a calculated error variance of less than 90 . The distribution of parameters after the unrealistic glacial anisotropies were removed and after the acceptance criteria were applied (fig. 15B) was slightly altered from the original parameter sets, but a generally lognormal or normal distribution is indicated.

Monte Carlo analyses were then done by use of the parameter sets that fit the acceptance criteria for the 1995 through 2003 average withdrawal rates but by using the 2007 through 2011 average withdrawal rates and the maximum withdrawal rates. The criteria for the Monte Carlo analyses that used the 467 parameter sets and these pumping rates were that the water budget be 1 percent or less for models that converged. For the average withdrawal rate from 2007 through 2011, 464 parameter sets (99 percent) fit these criteria and thus were run with the particle tracking program. For the maximum withdrawal rates, 457 parameter sets (98 percent) fit these criteria. The probability that a recharge location would be in the area contributing recharge to the production wells was determined by dividing the number of times a particle at a given location was captured by a well by the total number 

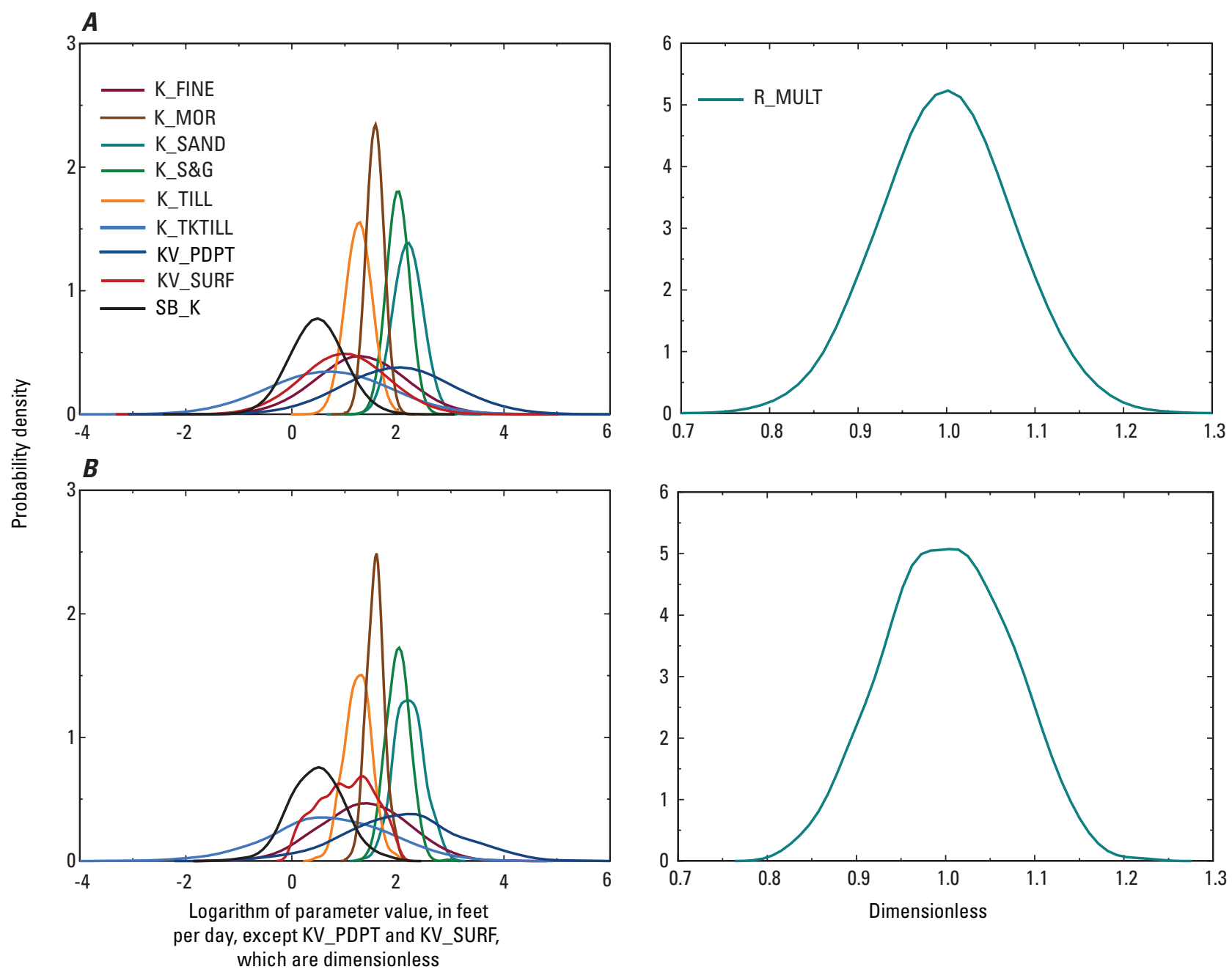

Figure 15. Model-parameter distributions $A$, before and $B$, after acceptance criteria were applied to determine the probabilistic areas contributing recharge to the well centers in the Chipuxet River and Chickasheen Brook Basins, Rhode Island. Parameters are listed in table 2.

of accepted particle-tracking simulations; this probability was expressed as a percentage.

The probabilistic areas contributing recharge to the production wells for the average pumping rates from 2007 through 2011 are shown in figure 16, and the probabilistic areas at the maximum pumping rates are shown in figure 17. For this analysis, the probabilistic distribution is not by well but by well center - the closely spaced wells adjacent to the Chipuxet River and well KWD-3 adjacent to Genesee Brook. Probabilistic contributing areas to individual wells might overlap, even though the deterministic contributing areas do not overlap under a steady-state simulation. The total size of the probabilistic contributing area for each well center for both average and maximum pumping rates was larger than the deterministic contributing areas for the well center because of the effects of parameter uncertainty. This indicated that some areas not in the deterministic contributing area, including additional areas of urban and agricultural land use, might actually be in the contributing area. In most cases, areas with high probabilities (more than 40 percent) generally coincided with the deterministic contributing areas for this model.

The probabilistic contributing areas to the production wells adjacent to the Chipuxet River for both pumping scenarios (figs. 16 and 17) indicated additional areas on both sides of the Chipuxet River that might be in the contributing area. Low probabilities are generally in areas distant from the pumping wells and in areas where simulated streams intercepted precipitation recharge in the deterministic model. Stream cells representing White Horn Brook in the valley-fill deposits and Chickasheen Brook downstream of Barber Pond 

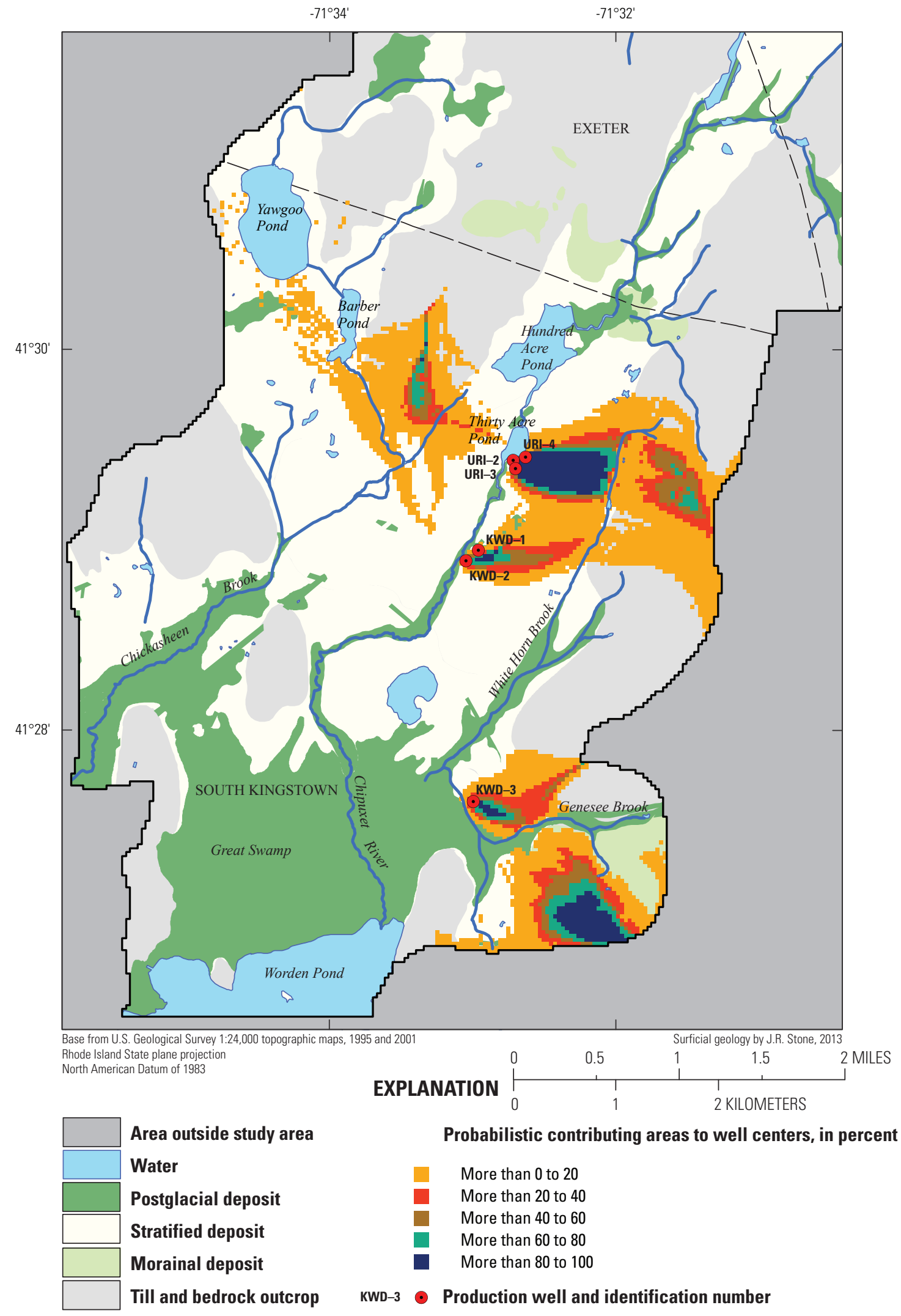

Area outside study area

Water

Postglacial deposit

Stratified deposit

Morainal deposit

Till and bedrock outcrop

Probabilistic contributing areas to well centers, in percent

More than 0 to 20

More than 20 to 40

More than 40 to 60

More than 60 to 80

More than 80 to 100

KWD-3 Production well and identification number

Figure 16. Simulated probabilistic areas contributing recharge to the well centers at their average pumping rates from 2007 through 2011 in the Chipuxet River and Chickasheen Brook Basins, Rhode Island. 
simulated as weakly gaining or losing in the deterministic model. Additional areas that might be in the contributing area included recharge originating near the pumping wells that have relatively short groundwater-flow paths and traveltimes. For the average pumping rate, the highest probabilities on the opposite side of the Chipuxet River from the wells are in the uplands and near the upland-valley contact at and adjacent to the deterministic contributing area. Extensive areas of low probabilities are associated with the remaining part of this till hillslope and along the axis of the Chickasheen Brook Valley. For the maximum pumping rate, the deterministic contributing area that extends a large distance along the axis of the Chickasheen Brook Valley (fig. 13) coincides with decreasing probabilities with increasing distance and traveltimes from the pumping wells; small isolated areas of the deterministic contributing area west and northwest of Barber Pond are associated with low probabilities. Also, extensive areas associated with low probabilities are along groundwater divides in upland areas on both sides of the Chipuxet River for the maximum pumping rate.

For production well KWD-3 adjacent to Genesee Brook, the probabilistic contributing areas for both pumping scenarios (figs. 16 and 17) indicated that additional areas in the Genesee Brook Basin might be in the contributing area, and for the maximum pumping rate, additional areas associated with low probabilities might be in the lower part of White Horn Brook Basin. The part of a sand and gravel mining operation that is not in the deterministic contributing areas is in the probabilistic contributing areas for both pumping scenarios. This additional area in the sand and gravel mining operation is associated with probabilities of more than 0 to 40 percent for the average pumping rate and more than 0 to 60 percent for the maximum pumping rate.

\section{Effects of Climate Change on the Groundwater System}

Climate projections from GCMs were used to investigate the hydrologic response to climate change in the Chipuxet River and Chickasheen Brook Basins. Climate variables from five downscaled GCMs and two emission scenarios were used in the calibrated SWB model to evaluate potential changes to the water balance near the land surface. Recharge rates from the SWB simulations were then inputted to the groundwaterflow models to evaluate the effect of climate change on groundwater hydrology. The effects of climate change were assessed by comparing three 30 -year periods in the 21 st century with an historical baseline period in the late 20th century, from 1970 through 1999 . The 30 -year periods in the 21 st century were (1) early century, from 2010 through 2039; (2) midcentury, from 2040 through 2069; and (3) late century, from 2070 through 2099.

\section{General Circulation Models and Emission Scenarios}

Climate projections for the 21st century were determined for the study area based on downscaled output from GCMs driven by emission scenarios. Five GCMs and two emission scenarios were used in the climate change analyses. Multiple GCMs were used because of the uncertainty in predicting how climate might respond to greenhouse gases and two emission scenarios were used because of the uncertainty in predicting future development. Output of climate variables from coarseresolution GCMs was statistically downscaled to daily temperature and precipitation for the continental United States with a resolution of one-eighth degree by Hayhoe and others (2013). The statistically downscaling method of the asynchronous regional regression model is described by Stoner and others (2013). Temperature and precipitation were downscaled to a scale for local environmental studies by calibration to gridded historical observed climate data developed by Maurer and others (2002). This historical observed climate was the same dataset used to calibrate the SWB model and the groundwater-flow models described in the previous sections. The downscaled climate data were available from the USGS Climate Geo Data Portal (http://cida.usgs.gov/climate/gdp/).

The two emission scenarios used in this study, B1 and A2, described in the Intergovernmental Panel on Climate Change Special Report on Emission Scenarios (Nakićenović and others, 2000) represent lower and higher emissions of greenhouse gases. The emission scenarios represent different projected changes in global population, technology, energy use, and other socioeconomic factors in the 21 st century. Emission scenarios B1 and A2 reach atmospheric carbon dioxide concentrations by 2100 about double and triple, respectively, preindustrial levels of 280 parts per million (ppm). Observed increases in carbon dioxide concentrations in the 21 st century are similar to projections from the suite of high emissions scenarios (Hayhoe and others, 2013).

Of the available downscaled GCMs, five models fitted the following criteria: (1) both emission scenarios B1 and A2 were simulated, (2) daily minimum and maximum temperature and precipitation were continuous through 2099, and (3) a year was represented by 365 days (some models used 360 days). Three of the GCMs were from North American institutions and two were from European institutions (table 3). A subset of the gridded climate projections was extracted from the USGS Climate Geo Data Portal for the coordinates that represented the Chipuxet River and Chickasheen Brook Basins.

\section{Projected Changes in Local Climate}

Projected seasonal and annual temperature and precipitation changes for the three 30 -year periods in the 21 st century - early 21 st century (2010-2039), mid- 21 st century (2040-2069), and late 21st century (2070-2099) relative to the 
$\boldsymbol{A}$ $\begin{array}{lr}-71^{\circ} 34^{\prime} & -71^{\circ} 32^{\prime}\end{array}$

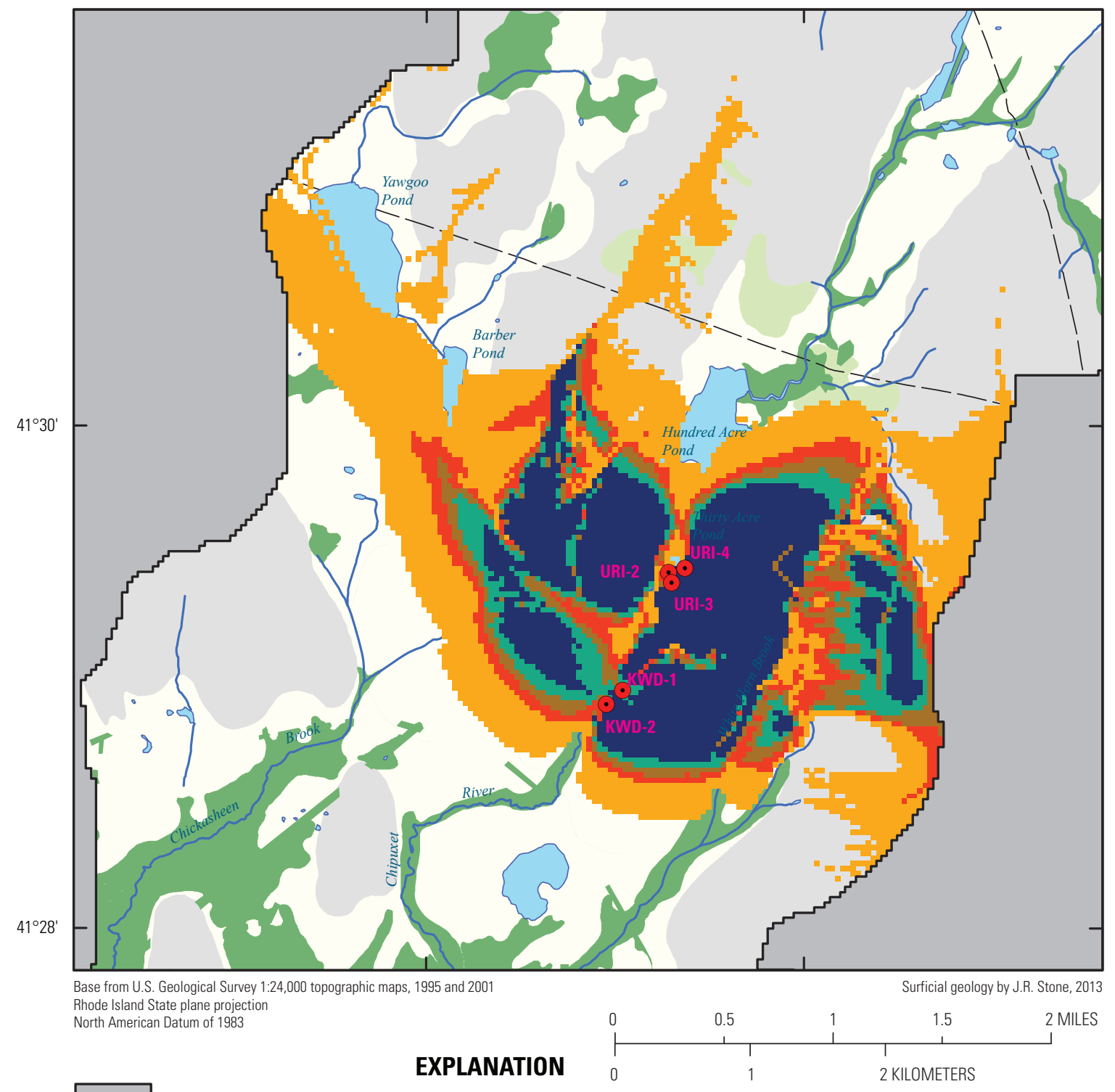

\begin{tabular}{|l|l|}
\hline & Area outside study area \\
& Water \\
\hline \hline Postglacial deposit \\
\hline Stratified deposit \\
Morainal deposit \\
Till and bedrock outcrop
\end{tabular}

Probabilistic contributing areas to well centers, in percent

More than 0 to 20

More than 20 to 40

More than 40 to 60

More than 60 to 80

More than 80 to 100

KWD-2 Production well and identification number

Figure 17. Simulated probabilistic areas contributing recharge to $A$, the well center adjacent to the Chipuxet River and $B$, well KWD-3 adjacent to the Genesee Brook, at their maximum pumping rates in the Chipuxet River and Chickasheen Brook Basins, Rhode Island. 


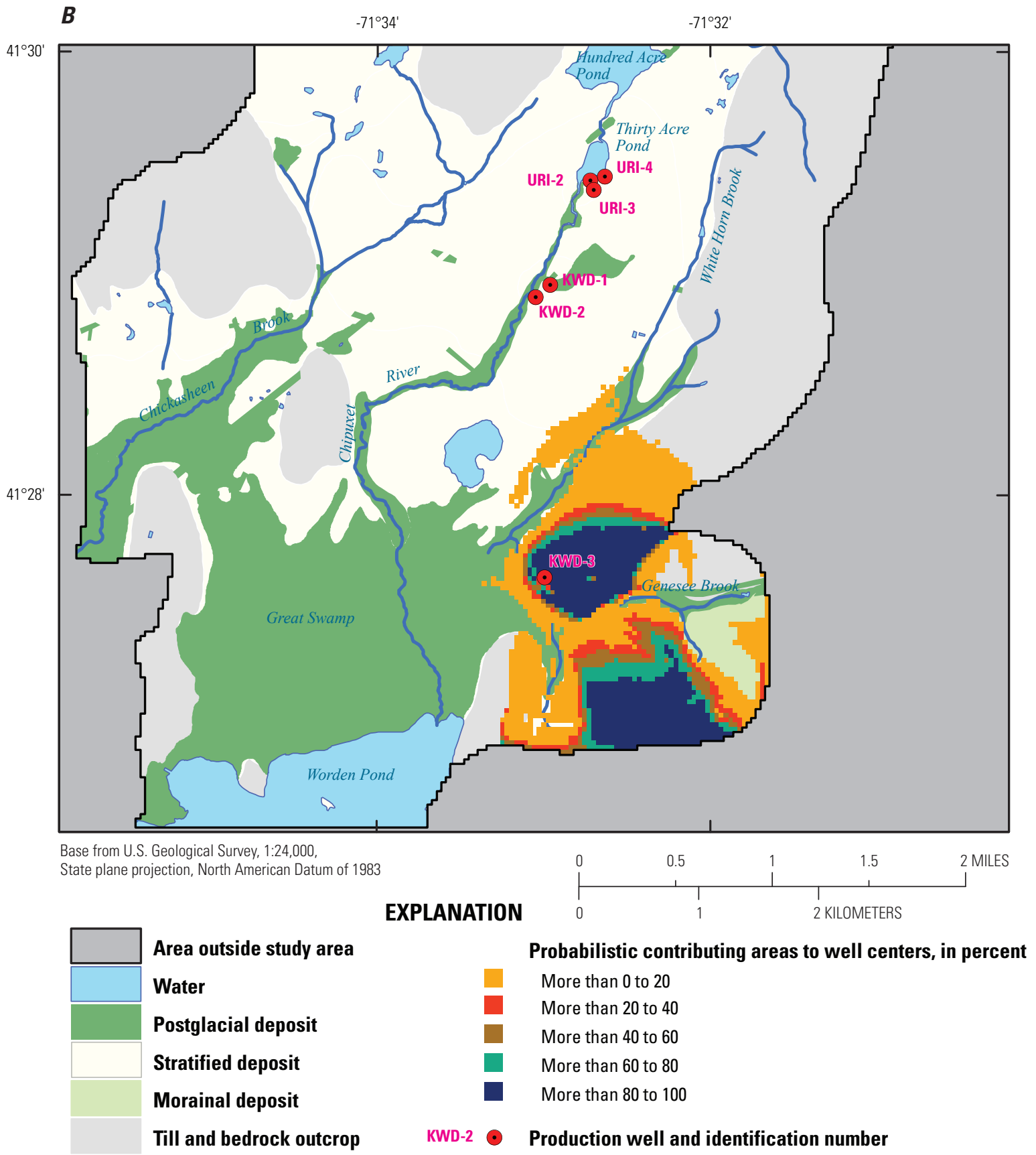

Figure 17. Simulated probabilistic areas contributing recharge to $A$, the well center adjacent to the Chipuxet River and $B$, well KWD-3 adjacent to the Genesee Brook, at their maximum pumping rates in the Chipuxet River and Chickasheen Brook Basins, Rhode Island.-Continued 
Table 3. General circulation models used in the climate change analysis in the Chipuxet River and Chickasheen Brook Basins, Rhode Island.

\begin{tabular}{lll}
\hline \multicolumn{1}{c}{ GCM } & \multicolumn{1}{c}{ Institution } & \multicolumn{1}{c}{ Country } \\
\hline CCSM3 & National Center for Atmospheric Research & United States \\
CGCM3.1-T47 & Canadian Centre for Climate Modeling and Analysis & Canada \\
CNRM-CM3 & Centre National de Recherches Meterorologiques & France \\
ECHAM5/MPI & Max Planck Institue for Meteorology & Germany \\
GFDL CM2.1 & National Oceanic and Atmospheric Administration Geophysical & United States \\
& Fluid Dynamics Laboratory & \\
\hline
\end{tabular}

late 20th century (1970-1999) - are shown in figure 18 for the two emission scenarios B1 and A2. Average values of the five downscaled GCMs and the range in projections for individual GCMs are both shown. Temperatures are projected to increase for all GCMs for both emission scenarios in the 21 st century compared with the late 20th century. Projected increases in temperature (averages of the five GCMs) for the early 21 st century are similar for both emission scenarios, but by midcentury, scenario A2 indicates larger increases than scenario B1 annually and for all seasons. Mean annual temperatures are projected to increase by $4.7^{\circ} \mathrm{F}$ for scenario A2 compared with $3.6^{\circ} \mathrm{F}$ for scenario $\mathrm{B} 1$ by midcentury and by $8.0^{\circ} \mathrm{F}$ for scenario A2 compared with $4.7^{\circ} \mathrm{F}$ for scenario B1 by late century. By midcentury, both emission scenarios indicate slightly larger increases in projected temperature for summer and fall compared with winter and spring.

Mean annual precipitation is also projected to increase for both emission scenarios in the 21 st century compared with the 20th century (fig. 18). The two emission scenarios indicate similar mean annual precipitation increases, with increases projected to be 7 percent for scenario B1 and 8 percent for scenario $\mathrm{A} 2$ by the late 21 st century. The seasonal distribution in precipitation changes is projected to vary for both emission scenarios (fig. 18). Winter, spring, and summer precipitation is projected to increase, whereas fall precipitation is expected to be the same or to decrease. Within an emission scenario, early 21 st century increases are similar for winter, spring, and summer, but as the 21 st century progresses, winter and spring precipitation changes increase further. Changes in fall precipitation continue to decrease through time for both emission scenarios. Seasonal increases and decreases in precipitation are generally similar for both emission scenarios (within a few percentages) except for winter precipitation, which is 6 percent larger for scenario A2 compared with scenario B1 for both midcentury and late century. By the late 21 st century, winter and spring precipitation is projected to increase by about 12 percent for scenario B1 and 17 percent and 12 percent, respectively, for scenario A2. Summer precipitation is expected to increase by 6 percent, and fall precipitation, decrease by 5 percent for both emission scenarios by the late
21 st century. Projected precipitation changes show a large range of variation for the individual GCMs, including both increases and decreases seasonally and annually (fig. 18), indicating the uncertainty of precipitation changes to increases in greenhouse gases.

Projected increases in mean annual temperature by the late 21 st century for the study area are similar to those for a regional study of the northeastern United States (Hayhoe and others, 2007) and to localized studies in southern New England (Bjerklie and others, 2012; Tetra Tech, Inc., 2012) and coastal New Hampshire (Wake and others, 2011). Projected increases in mean annual precipitation by the late 21 st century are similar to those in the southern New England studies and the regional study but less than the increases projected for coastal New Hampshire.

\section{Projected Changes in Recharge, Actual Evapotranspiration, and Soil Moisture}

The source of all groundwater in the study area is ultimately from precipitation. Historically, most groundwater recharge occurs from fall, after the soil moisture deficient of the previous summer has been satisfied, to spring, before potential evapotranspiration is again close to or exceeds precipitation during the growing season. Thus predicted changes in temperature and precipitation in the 21 st century have the potential to affect the magnitude and timing of recharge compared with the 20th century. Downscaled daily minimum and maximum temperature and precipitation from each of the five GCMs were inputted to the calibrated SWB model. Output results from the SWB model referred to in this section (recharge, actual evapotranspiration, and soil moisture) are averages of the five GCMs averaged spatially over the study area for each emission scenario. Changes in soil moisture are expressed in percentages, but because rates of recharge in summer and actual evapotranspiration in winter are close to zero, small changes equate to large percentage changes. Instead, changes in these two water-balance components are shown graphically in inches. 

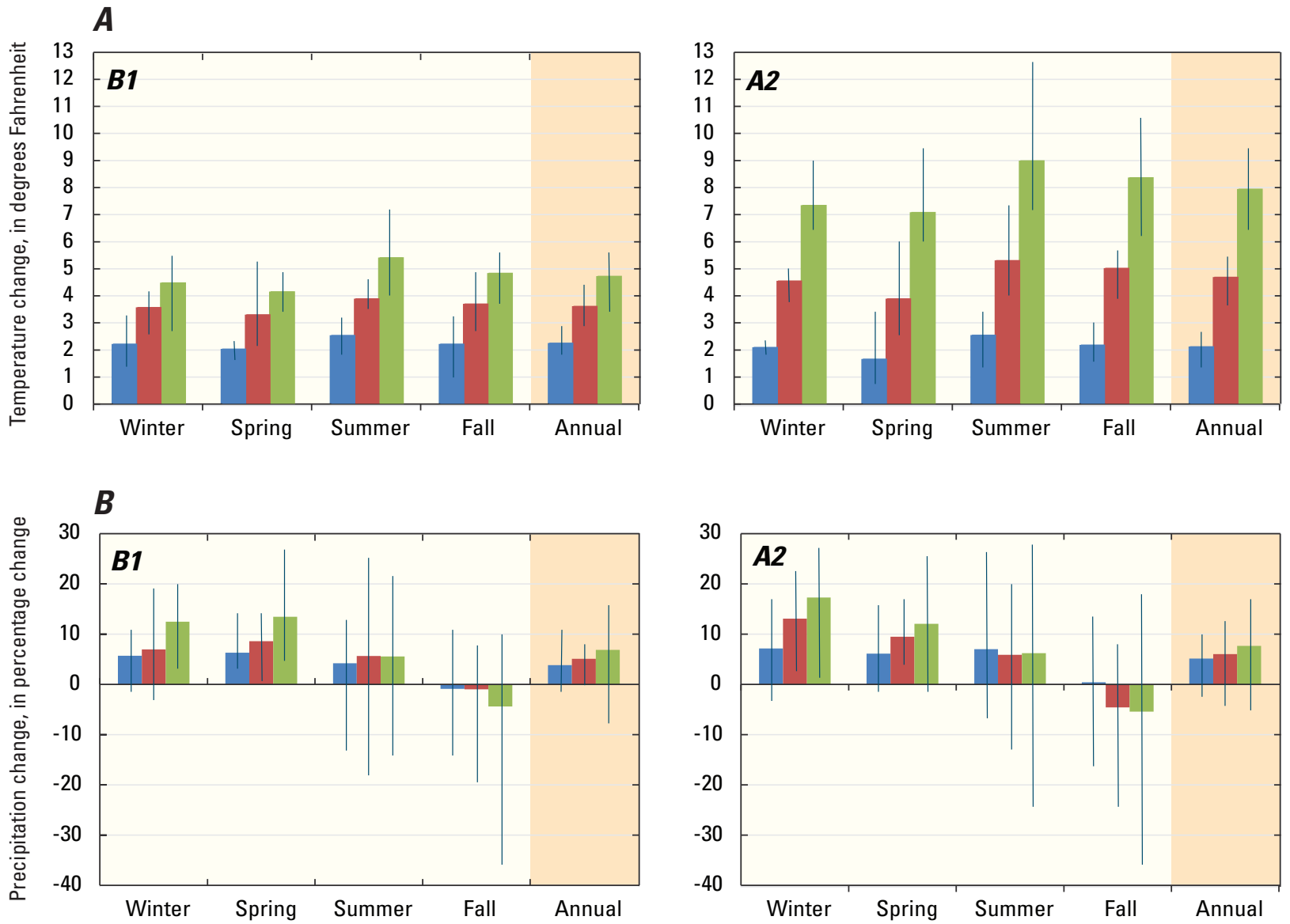

\title{
EXPLANATION
}

\author{
- 2010-39 \\ 2040-69 \\ 2070-99 \\ Range of projections from GCMs
}

Figure 18. Seasonal and annual projected changes in $A$, temperature and $B$, precipitation for three periods in the 21st century (2010-39, 2040-69, and 2070-99) compared with those in the late 20th century (1970-99) for two greenhouse gas emission scenarios (B1, lower emissions and A2, higher emissions) in the Chipuxet River and Chickasheen Brook Basins, Rhode Island. Projected values represent the averages of five general circulation models (GCMs), and the bars indicate the range of projections from individual GCMs. 
Projected changes in the magnitude and seasonal distribution of precipitation (increases in winter, spring, and summer, and decreases in fall) and in warming temperatures in the 21 st century affect the magnitude and timing of recharge compared with the 20th century (fig. 19). Recharge is projected to increase in winter, decrease in fall, and generally shows little change in spring and summer compared with the 20th century for both emission scenarios B1 and A2. In general, seasonal changes in recharge are larger for the higher emission scenario A2 compared with the lower emission scenario B1. Through the 21 st century, recharge increases in winter and decreases in fall become larger for both emission scenarios. By the end of the 21 st century, winter recharge increases by 1.3 in., representing a percentage change of 13 percent for scenario B1, and by 1.6 in. or 15 percent for scenario A2. In fall, recharge diminishes by 0.6 in. or 13 percent for scenario B1 and by 1.2 in. or 24 percent for scenario A2. By the end of the 21st century, scenario A2 also shows a substantial change in spring recharge compared with the late 20th century with a decrease of 0.6 in. or 7 percent. Although recharge is projected to change seasonally in the 21 st century, mean annual recharge shows minimal percentage change. Mean annual recharge for the 30-year periods in the 21st century increases by 1 to 4 percent for scenario $\mathrm{B} 1$, and for scenario $\mathrm{A} 2$, ranges from a decrease of 1 percent to an increase of 4 percent.

Although precipitation is projected to increase for three of the four seasons, most recharge increases are projected in the cooler winter months. In the SWB model, there are three components of water loss that do not contribute to recharge: interception by vegetation cover, surface runoff, and actual evapotranspiration. Actual evapotranspiration is the predominant loss. As a percentage of precipitation, these water-balance components increase through the 21 st century. Figure 20 illustrates the changes in actual evapotranspiration in the $21 \mathrm{st}$ century compared with the 20th century.

In the 21 st century, actual evapotranspiration is projected to increase in winter and spring for both emission scenarios because of rising temperatures, and in summer because of increased available moisture from precipitation as well as rising temperatures. In fall, actual evapotranspiration is projected to increase or show little change; for some 30-year periods, the early fall months (September and October), which have the largest decrease in precipitation, show a decrease in actual evapotranspiration. For most seasons, actual evapotranspiration increases with rising temperatures through the 21 st century, and emission scenario A2, with its larger temperature changes, has larger actual evapotranspiration increases compared with scenario B1. By midcentury, spring evapotranspiration is projected to increase the most, about one-half of the mean annual evapotranspiration increases for both emission scenarios. By late century, projected increases in mean annual evapotranspiration are 1.9 in. or 11 percent for scenario B1 and $3.9 \mathrm{in}$. or 22 percent for scenario A2. Only in winter do projected increases in precipitation substantially exceed predicted increases in actual evapotranspiration, thereby increasing recharge in winter compared with the 20th century.
Soil moisture is projected to decrease in the 21 st century from spring through fall because of increases in potential evapotranspiration, and in fall because of decreases in precipitation in addition to increases in potential evapotranspiration (fig. 21). Soil moisture decreases are expected to become larger as the 21st century progresses. By midcentury, soil moisture decreases for emission scenario A2 are projected to be larger than for emission scenario B1 because of larger temperature increases. Summer and fall are predicted to have the largest decreases. By the late 21st century, soil moisture for emission scenario B1 is expected to decrease by 11 percent in summer and 15 percent in fall, and for emission scenario A2, decrease by 23 percent for both seasons. These decreases in soil moisture during the growing season are likely to have implications for agriculture in southern Rhode Island.

\section{Projected Changes in Groundwater Hydrology}

Groundwater flow simulations can provide insights into the effects of changing recharge rates in the 21 st century (increases in winter and decreases in fall) on groundwater resources in the study area. Effects on base flow (groundwater discharge) and groundwater levels were calculated by comparing average monthly conditions for the 30 -year periods in the 21 st century with the 30 -year period in the late 20th century using transient model simulations. An analysis of the effects on areas contributing recharge was accomplished by comparing the sources of water to the production wells for the 21 st century with those for the 20th century with steady-state model simulations.

The only change made to the calibrated groundwater-flow models was recharge rates. For the transient model, spatially distributed monthly recharge rates from the SWB model for the five GCMs were averaged by model cell to create a monthly mean for each emission scenario. For the steady-state model, spatially distributed 30-year average recharge rates from the SWB model for the GCMs were also averaged by model cell. Other factors besides recharge rates that might affect groundwater resources due to climate change, such as changing land cover and water usage, were not included in the model simulations. For example, predicted decreases in soil moisture because of increasing temperatures will likely change water usage for agriculture, lawns, and recreational fields that might further affect water resources.

\section{Base Flow}

Simulated average monthly base flow at the Chipuxet River streamgage (drainage area of $9.35 \mathrm{mi}^{2}$ ) for the three 30 -year periods in the 21 st century for both emission scenarios has the same seasonal pattern as the 30 -year period in the late 20th century - highest flows in March and lowest flows in September (fig. 22; only late 20th and 21st century flow rates shown). Because of increased recharge in winter (December [D], January [J], and February [F]) in the 21st century 


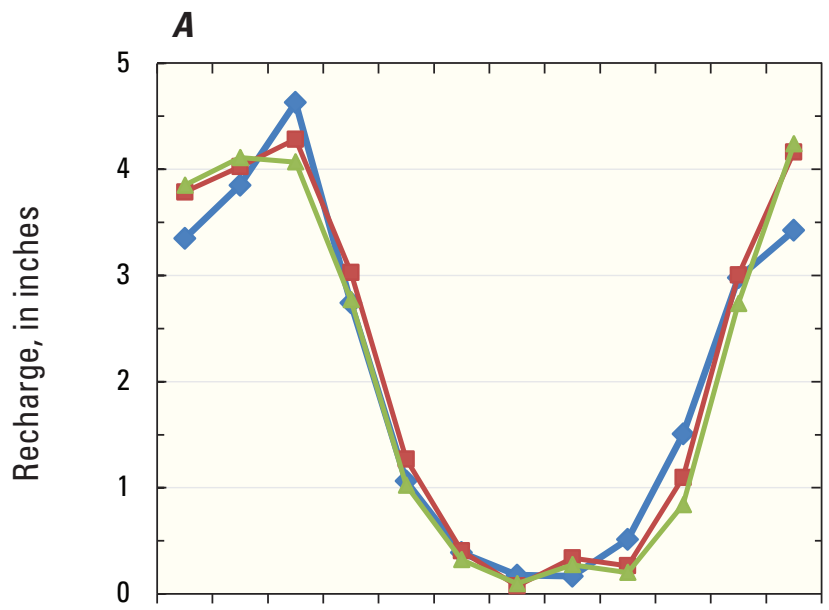

Jan. Feb. Mar. Apr. May June July Aug. Sept. Oct. Nov. Dec.

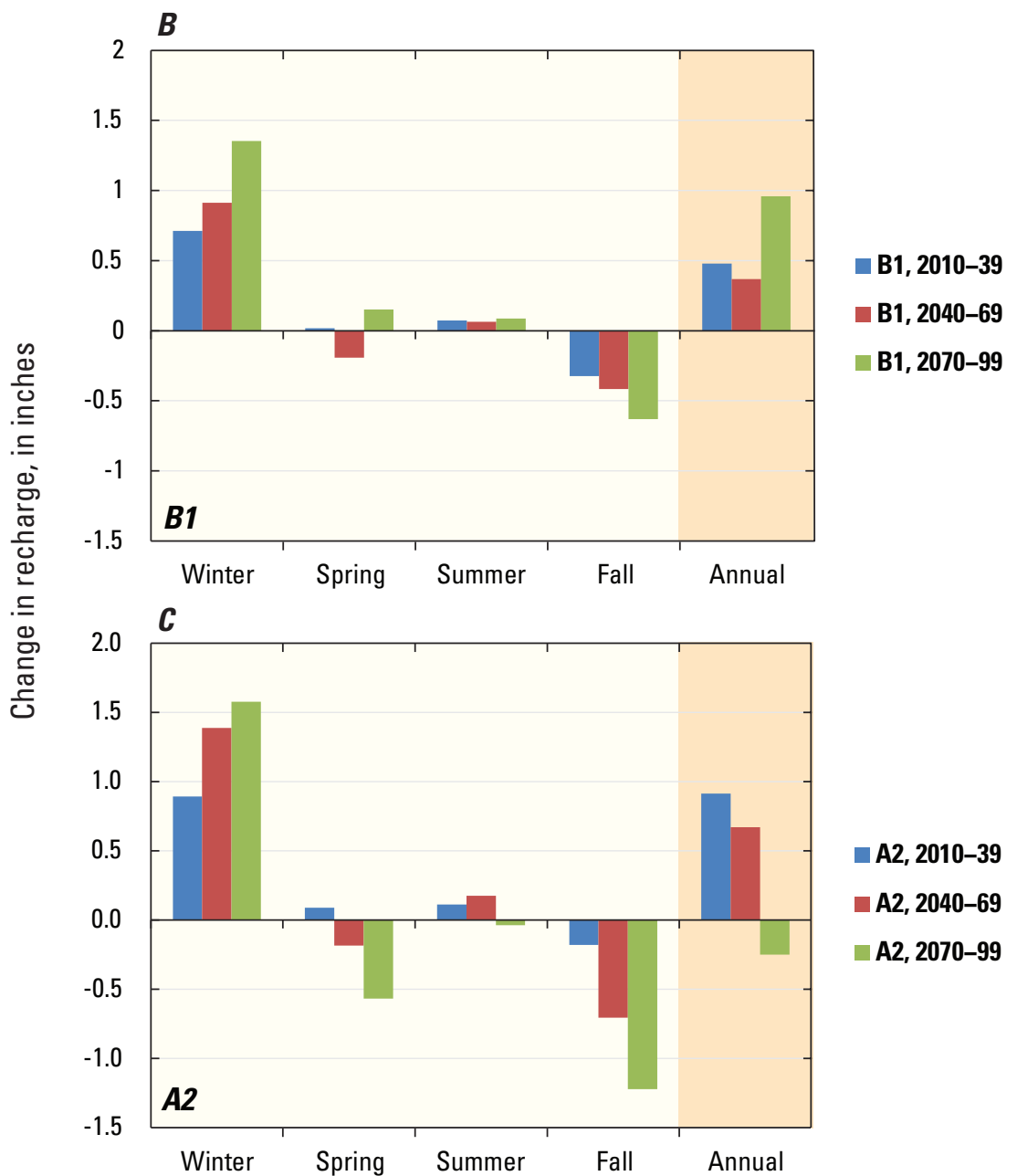

Figure 19. $\quad A$, Calculated recharge for the late 20th century (1970-99) and the late 21st century (2070-99) for two greenhouse gas emission scenarios (B1, lower emissions and $\mathrm{A} 2$, higher emissions) and changes in recharge for three periods in the 21st century (2010-39; 2040-69, and 2070-99) relative to the late 20th century (1970-99) for emission scenarios $B, \mathrm{~B} 1$ and $C, \mathrm{~A} 2$ in the Chipuxet River and Chickasheen Brook Basins, Rhode Island. Projected values represent study-area-wide-averages of five general circulation models. 

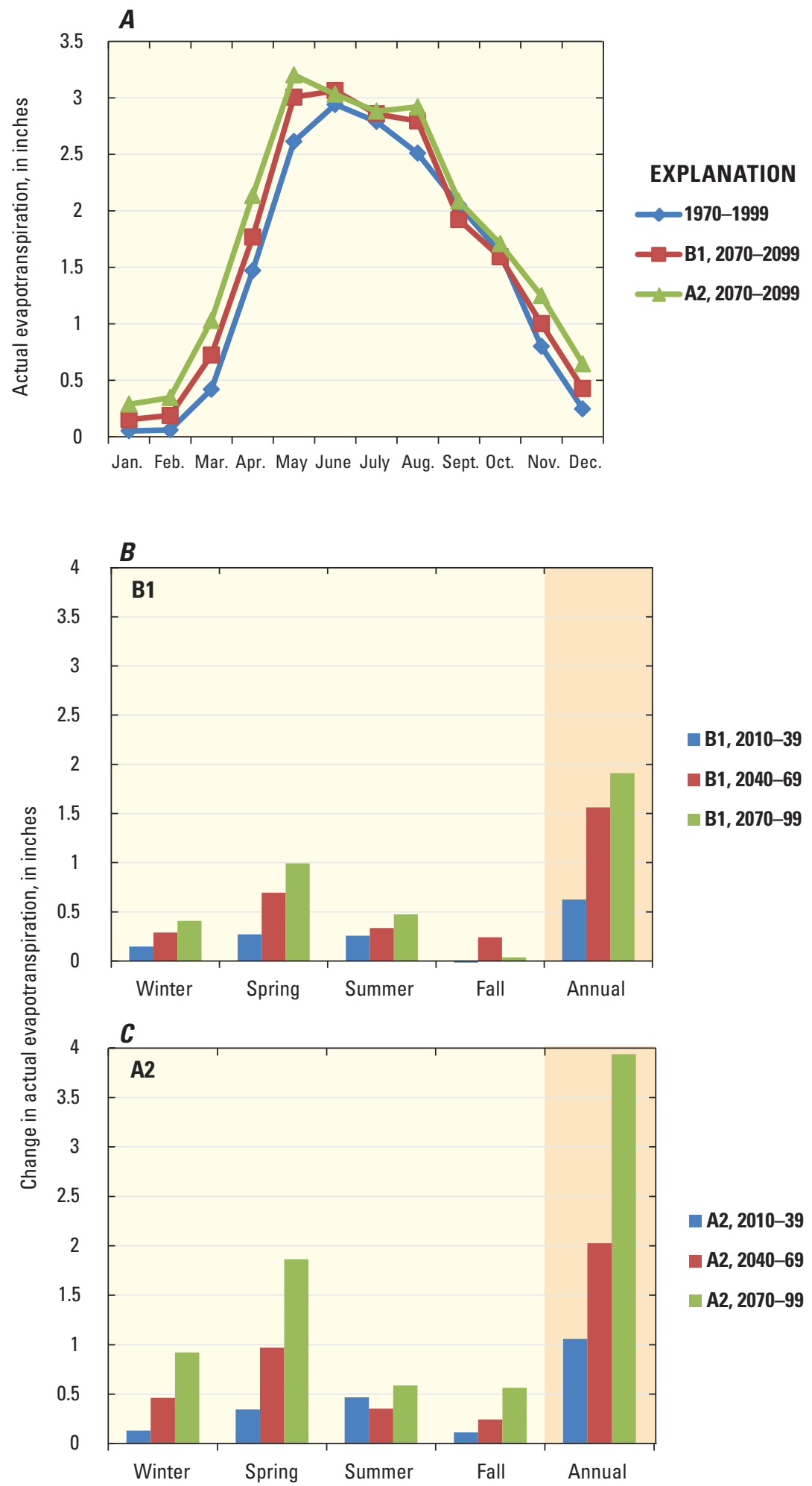

Figure 20. $A$, Calculated actual evapotranspiration for the late 20th century (1970-99) and the late 21st century (2070-99) for two greenhouse gas emission scenarios (B1, lower emissions and $A 2$, higher emissions) and changes in actual evapotranspiration for three periods in the 21st century (2010-39; 2040-69, and 2070-99) relative to the late 20th century (1970-99) for emission scenarios $B$, B1 and $C, A 2$ in the Chipuxet River and Chickasheen Brook Basins, Rhode Island. Projected values represent study-area-wide-averages of five general circulation models. 


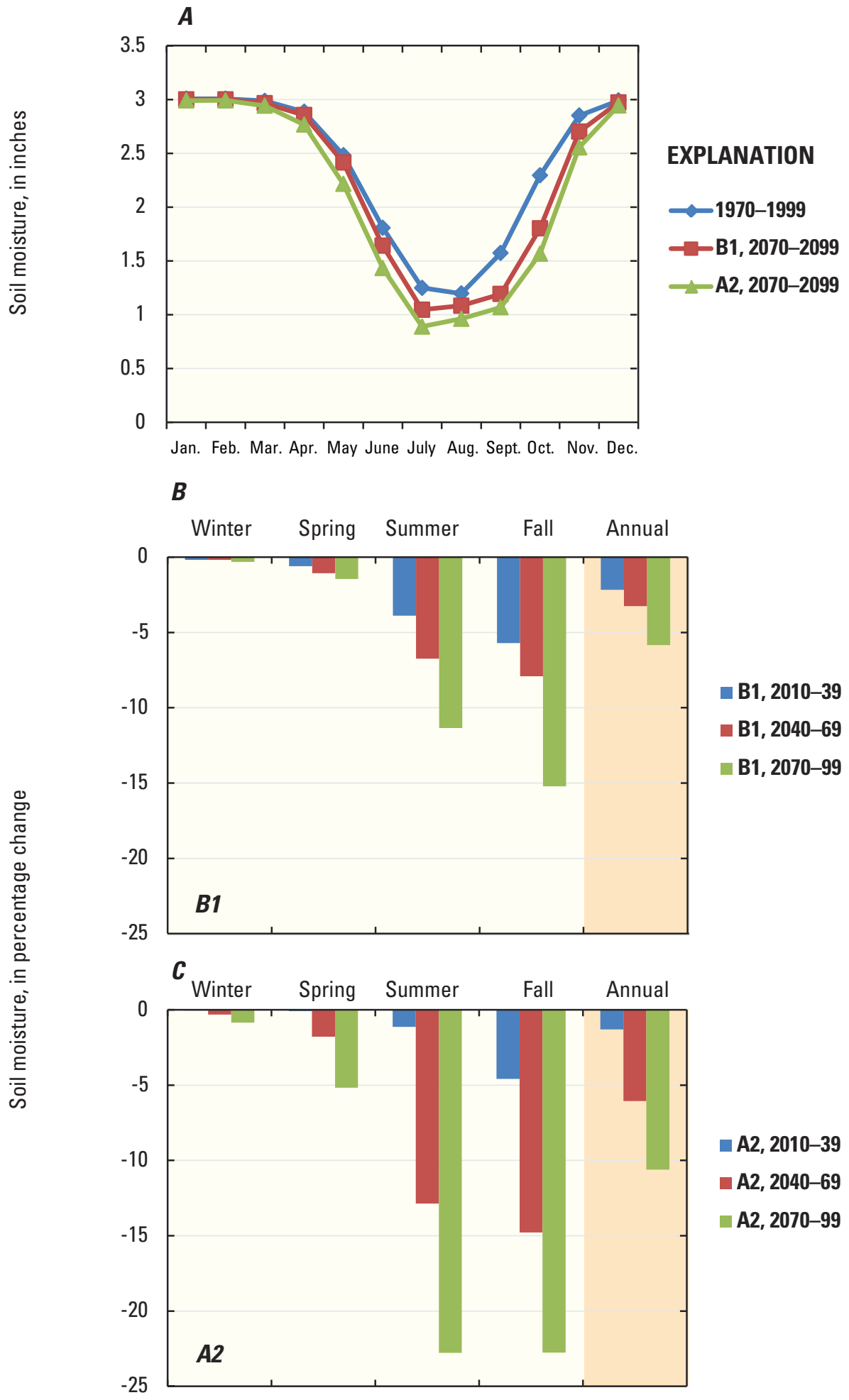

Figure 21. A, Calculated soil moisture for the late 20th century (1970-99) and the late 21st century (2070-99) for two greenhouse gas emission scenarios (B1, lower emissions and A2, higher emissions) and changes in soil moisture for three periods in the 21st century (201039; 2040-69, and 2070-99) relative to the late 20th century (1970-99) for emission scenarios $B, \mathrm{~B} 1$ and $C, \mathrm{~A} 2$ in the Chipuxet River and Chickasheen Brook Basins, Rhode Island.

Projected values represent study-area-wide-averages of five general circulation models. 

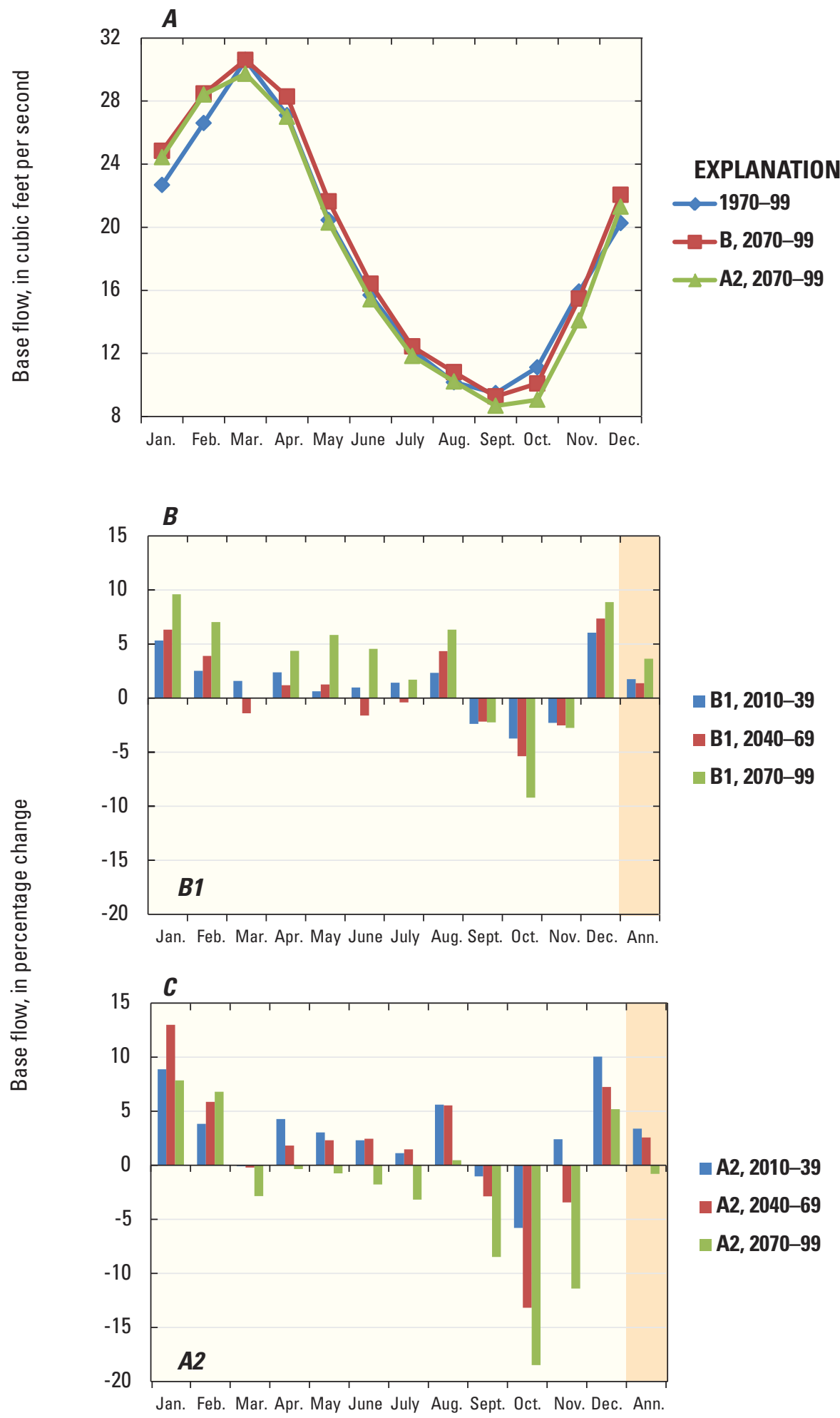

Figure 22. A, Simulated base flow to the Chipuxet River for the late 20th century (1970-99) and the late 21st century (2070-99) for two greenhouse gas emission scenarios (B1, lower emissions and $A 2$, higher emissions) and changes in base flow for three periods in the 21st century (2010-39; 2040-69, and 2070-99) relative to the late 20th century (1970-99) for emission scenarios $B, \mathrm{~B} 1$ and $C, A 2$ in the Chipuxet River and Chickasheen Brook Basins, Rhode Island. Projected values represent the averages of five general circulation models. 
compared with the late 20th century, base flows in winter are larger than flows in the late 20th century (fig. 22). Increase in base flows in winter is generally 5 to 10 percent in the 21 st century compared with the late 20th century for both emission scenarios. The peak base flow for the calendar year, in March, however, is similar. Because of less recharge in fall and less or about the same recharge in the preceding months of spring and summer, base flow in fall (September [S], October [O], and November [N]) is less in the 21 st century relative to the late 20th century for both emission scenarios. These decreases in fall base flow become larger through the 21 st century for all fall months for emission scenario A2 and for October for emission scenario B1. Base flow in September, the month with the lowest flows, is lower in the 21 st century relative to the late 20th century by a few percentages except for the late 21 st century under emission scenario $\mathrm{A} 2$, which is 8 percent less. October has the largest base flow decreases; by the late 21st century, base flow under emission scenario B1 decreases by 9 percent and under emission scenario A2 decreases by 18 percent, thereby extending the low-flow period of the year (late summer and early fall) by another month in the 21 st century. Although there is seasonal variation in base flow changes for both emission scenarios, mean annual base flows show minimal differences between the 21 st century and the late 20th century.

Simulated average monthly base flow and percentage changes to a small upland stream (drainage area of $0.9 \mathrm{mi}^{2}$ ) are also shown in figure 23 (location of site in fig. 5). This site drains predominately till deposits, which contrasts with the Chipuxet River streamgage site that drains an area of mixed surficial deposits. The upland drainage area overall has shorter groundwater-flow paths and traveltimes from recharging locations to discharge points along the stream than the larger area covered by the Chipuxet River streamgage. The thin till deposits and underlying bedrock also have lower storage values than the stratified deposits. Waibel and others (2013) reported that base flow in smaller basins tended to respond to seasonal changes in recharge caused by climate change more than larger basins in a study done in the northwestern United States.

Base flows at the till site also show a similar seasonal pattern in the 21 st century as in the 20th century for both emission scenarios (highest flow in March and lowest in September), but by the late 21 st century for emission scenario A2, February flow has increased and March flow has diminished to such an extent that there is a broad peak flow covering these months. Base flow in March decreases by 5 percent by the mid-21st century for both emission scenarios and the late 21 st century for emission scenario $\mathrm{B} 1$ and by 9 percent by late 21 st century for emission scenario A2. Winter base flows show similar percentage change increases as at the Chipuxet River streamgage, but fall base flows have larger decreases as a percentage of flow. By the late 21st century, September base flow decreases by 12 percent for emission scenario B1 and by 23 percent for emission scenario A2. For October, which has the largest monthly decreases throughout the 21st century, base flow diminishes by 28 percent for emission scenario B1 and by 42 percent for emission scenario $\mathrm{A} 2$ by the late $21 \mathrm{st}$ century. These large decreases in fall indicate that there might be more intermittent headwater streams in the 21 st century compared with the 20th century with corresponding effects on aquatic habitat.

\section{Groundwater Levels}

Simulated average monthly groundwater levels for the late 20th century and the late 21 st century at the long-term observation well SNW6 in the coarse stratified deposits (fig. 24) indicate similar responses to recharge changes as base flow. Because of seasonal changes in recharge due to climate change, groundwater levels in the late 21 st century are predicted to be higher in winter and lower in fall compared with the late 20th century. [Note that changes in monthly groundwater levels for the late 21 st century are generally larger than changes in the early and mid-21st century.] However, because of the storage capacity of coarse stratified deposits, these changes in groundwater levels are small in the area for most months. The groundwater level in September, the month with the lowest simulated water level, is the same in the late 21 st century for emission scenario B1 and slightly lower for emission scenario A2 as that in the late 20th century. October has the largest monthly changes in water levels for both emission scenarios, thus extending low water levels for the year later into fall.

The effect of climate change on water levels is also represented by maps of the difference in the water-table altitude between the late 21 st century and the late 20th century for September and October (fig. 25). Changes in water levels due to changes in recharge were predicted to be less in the valley-fill deposits than in the uplands because stratified and moraine deposits have larger storage values than till deposits and bedrock. In the valley-fill deposits, minimal head changes were predicted to be generally in low-lying areas with flat gradients and near gaining streams, which can control nearby aquifer heads. The largest water level changes in the valley-fill deposits were predicted to be generally distant to streams, near streams that are weakly gaining or losing, and near the valley edges. In September, predicted changes to groundwater levels were minimal in the valley for emission scenario B1. For emission scenario A2, groundwater level decreases of more than 0.25 to $0.50 \mathrm{ft}$ and more than 0.50 to $1.0 \mathrm{ft}$ were predicted for small areas of the valley. In October, groundwater levels were predicted to decrease by these same amounts in more areas of the valley than in September for both emission scenarios and by up to $2.5 \mathrm{ft}$ in small areas for emission scenario A2. Conceptually, perennial or intermittent streams downstream of the upland-valley contact where aquifer water levels can be below the streambed for all or part of the year might lose additional water after intense precipitation events in fall, thereby contributing additional aquifer recharge. 

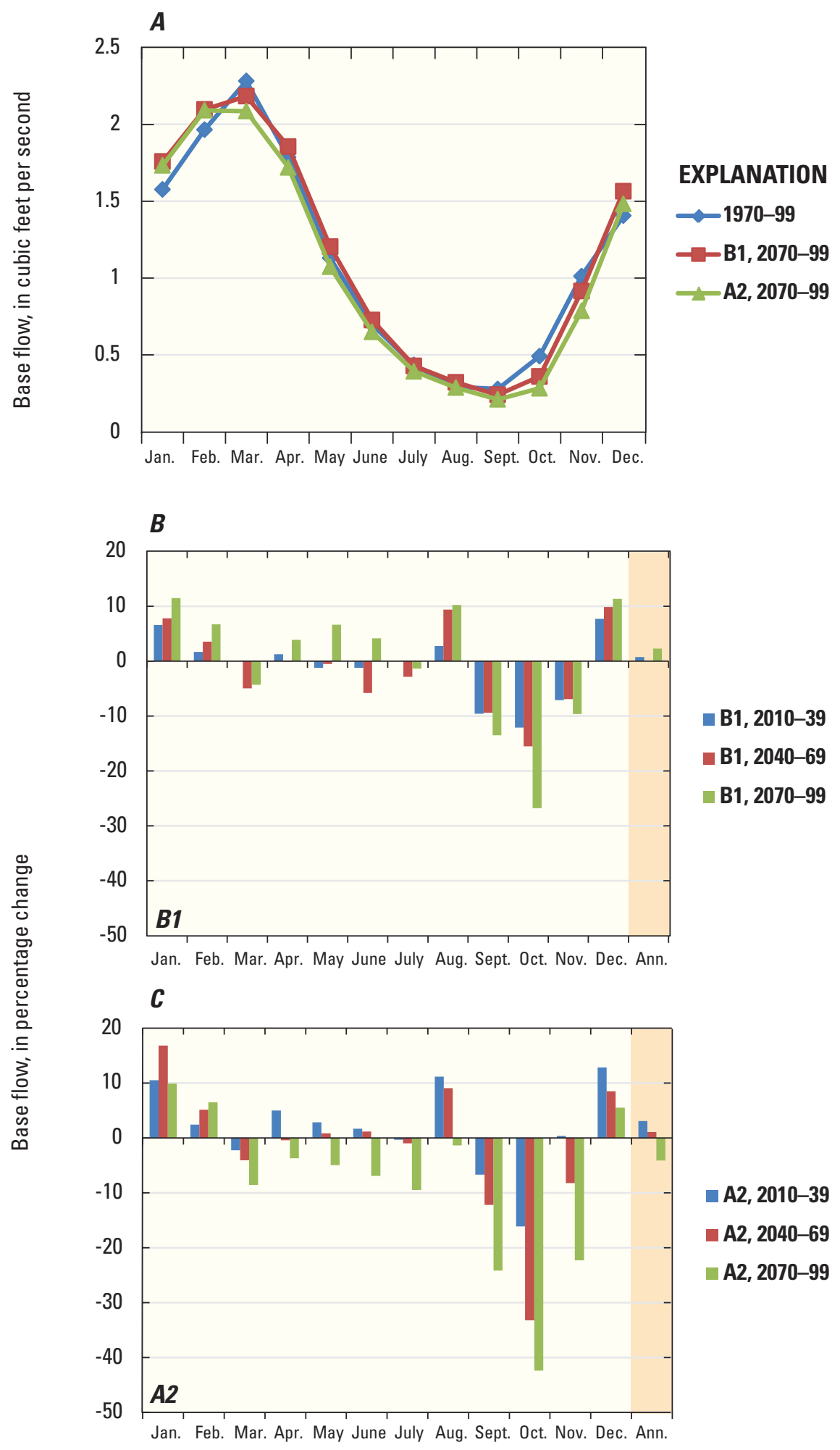

Figure 23. $A$, Simulated base flow to a tributary of the Chipuxet River for the late 20th century (1970-99) and the late 21st century (2070-99) for two greenhouse gas emission scenarios ( $B 1$, lower emissions and $A 2$, higher emissions) and changes in base flow for three periods in the 21st century (2010-39; 2040-69, and 2070-99) relative to the late 20th century (1970-99) for emission scenarios $B, \mathrm{~B} 1$ and $C, A 2$ in the Chipuxet River and Chickasheen Brook Basins, Rhode Island. Projected values represent the averages of five general circulation models. 


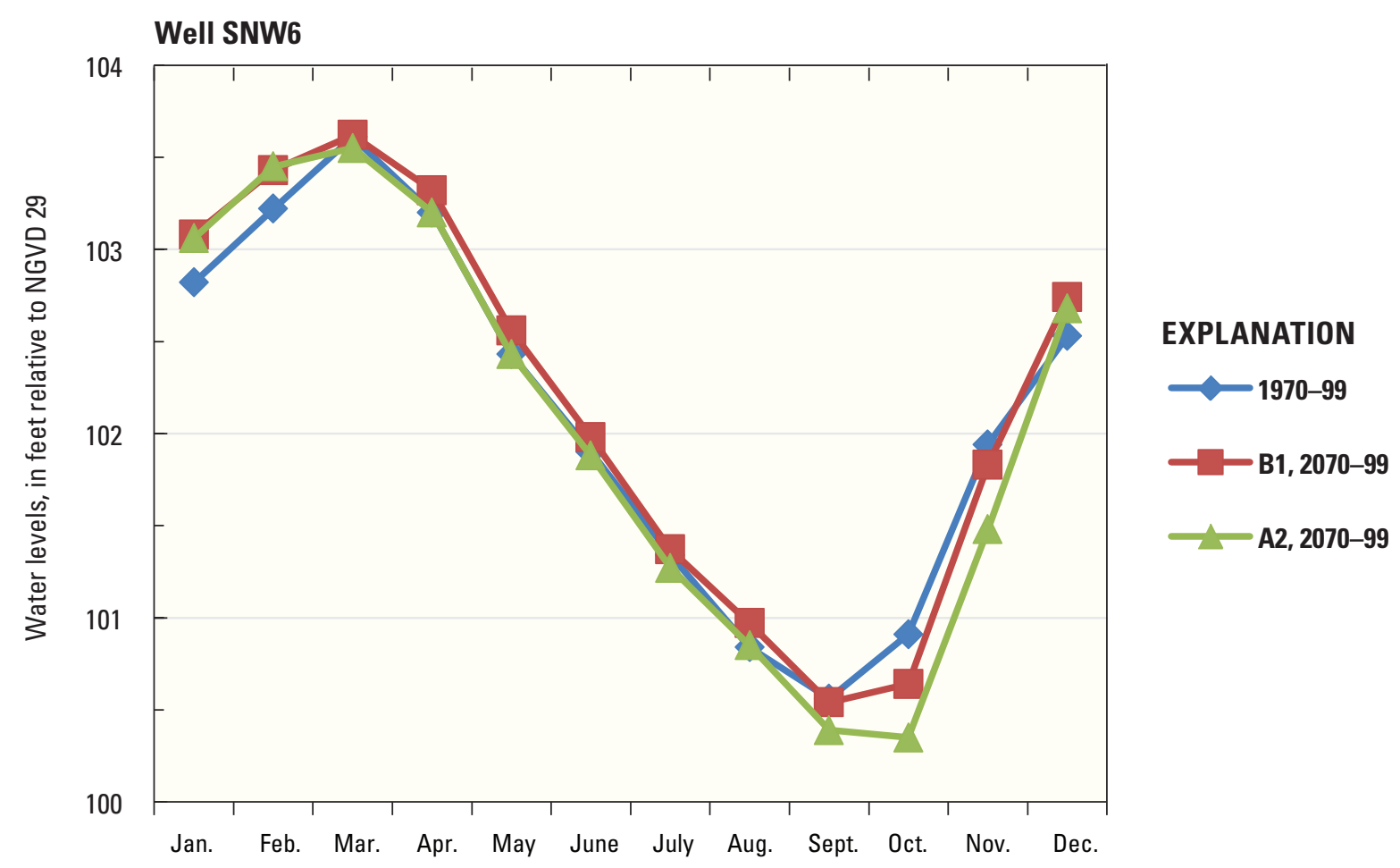

Figure 24. Simulated water-level altitudes at observation well SNW6 for the late 20th century (1970-99) and late 21st century (2070-99) for two greenhouse gas emission scenarios (B1, lower emissions and A2, higher emissions) in the Chipuxet River and Chickasheen Brook Basins, Rhode Island. Projected values represent the averages of five global circulation models.

The largest changes in groundwater levels between the late 21 st century and the late 20th century in the uplands (fig. 25) were predicted to be in areas where the simulated water table is in bedrock and in adjacent areas where the simulated water table drops below the thin surficial till deposits in the late 21 st century. In September, predicted changes in groundwater levels for emission scenario B1 were mostly in areas where the water table was in the bedrock in the historical period with decreases up to $5 \mathrm{ft}$. In small areas of till deposits, water levels were predicted to decrease by up to $1 \mathrm{ft}$. For emission scenario A2, water levels were predicted to decrease by up to $10 \mathrm{ft}$ in bedrock, and substantial areas of till deposits showed water level decreases of up to $2 \mathrm{ft}$. In October, the month with the largest water table changes, water levels were predicted to decrease by more than $10 \mathrm{ft}$ in bedrock areas under both emission scenarios. For emission scenario B1, large areas of till deposits showed water level decreases of up to $2 \mathrm{ft}$, and small areas of till deposits showed decreases of $5 \mathrm{ft}$. For emission scenario A2, water levels in large areas of till deposits were predicted to decrease by up to $5 \mathrm{ft}$, with water levels in small till areas predicted to decrease by as much as $10 \mathrm{ft}$. Thus climate change might affect groundwater levels in the uplands more than in the valley-fill deposits with their higher storage properties.

\section{Areas Contributing Recharge}

Predicted mean annual recharge for the 30-year periods in the 21 st century for both emission scenarios indicates small changes compared with the late 20th century, ranging from a decrease of 1 percent to an increase of 4 percent. These changes in the long-term average recharge are from spatially averaged values for the study area and might not represent the average recharge in the well-field areas; the predictions also do not take into account interactions between groundwater and surface water.

A comparison of simulated areas contributing recharge to the production wells with the 21 st century recharge rates to the 20th century confirms that the locations and sizes of the contributing areas are predicted to change minimally (contributing areas not shown). Changes to the total size of the contributing areas to the production wells for both average and maximum pumping rates for each 30-year period and for both emission scenarios are within 3 percent of the simulated contributing areas in the 20 th century. 


\section{A. September} $-71^{\circ} 34^{\prime}$ $-71^{\circ} 32^{\prime} \quad-71^{\circ} 30^{\circ}$
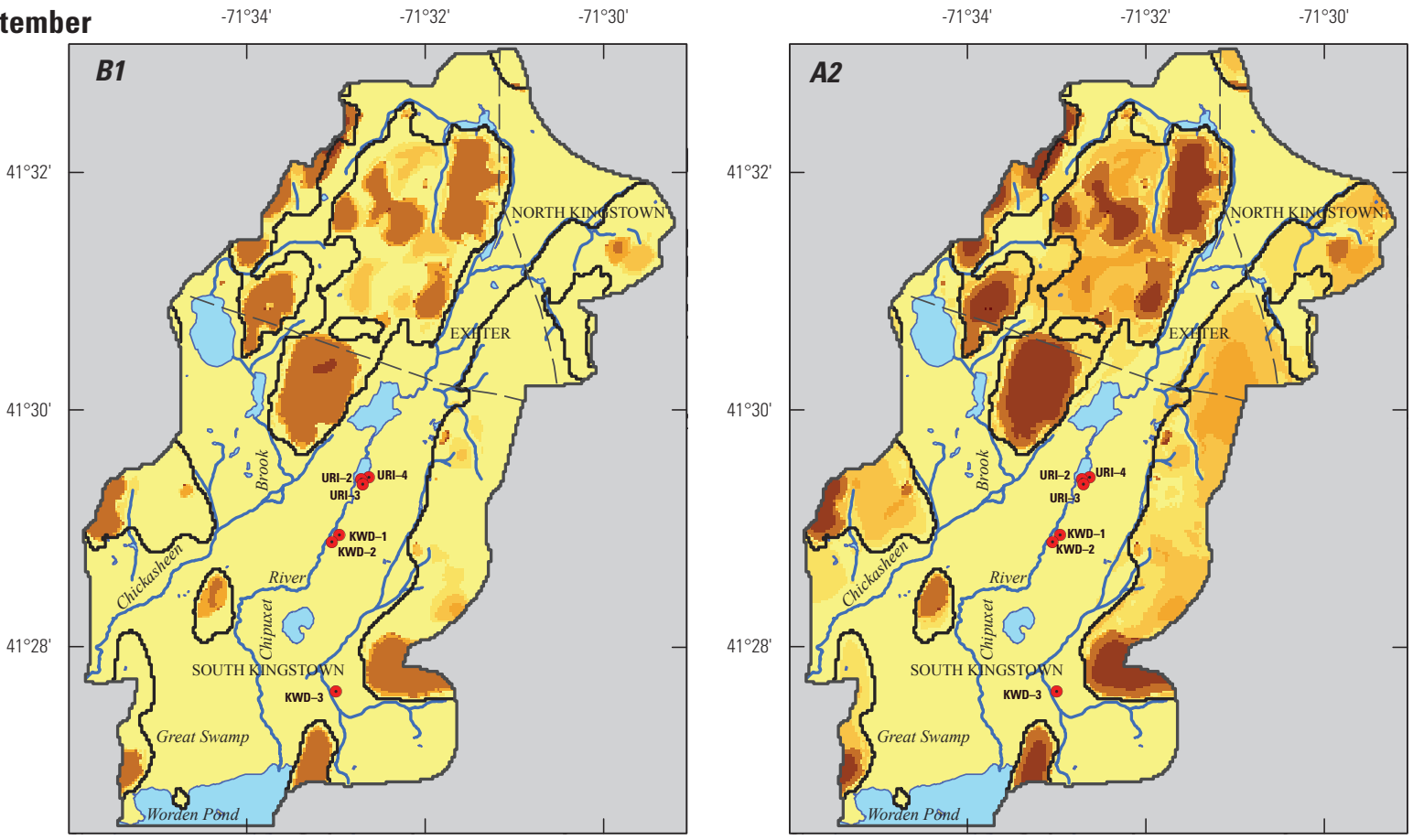

\section{B. October}

$-71^{\circ} 34^{\prime}$

$-71^{\circ} 32^{\prime}$

$-71^{\circ} 30^{\circ}$
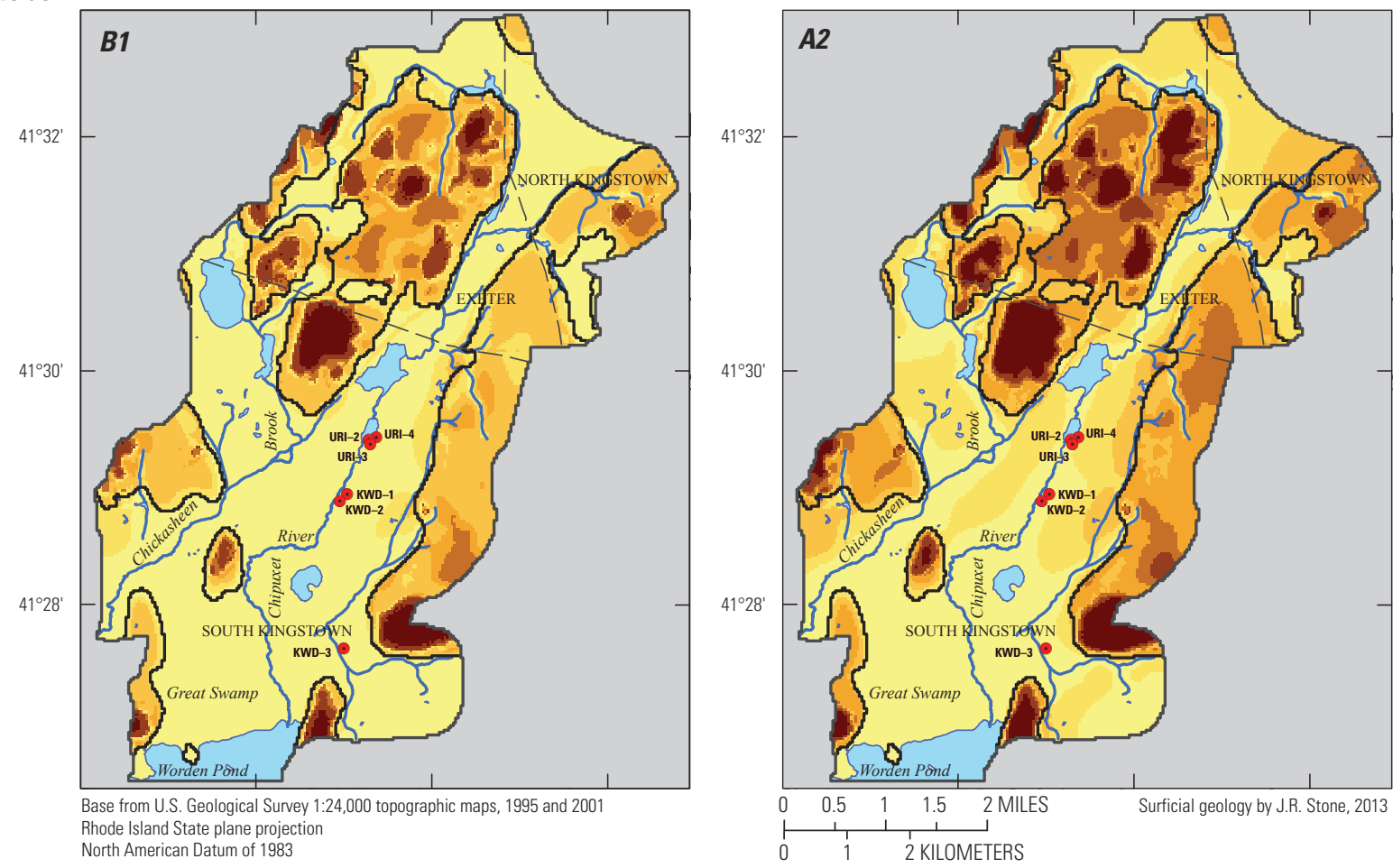

EXPLANATION

Area outside study area

Change in simulated water table altitude, in feet

Water

Contact between uplands and valley

Production well, and identification number
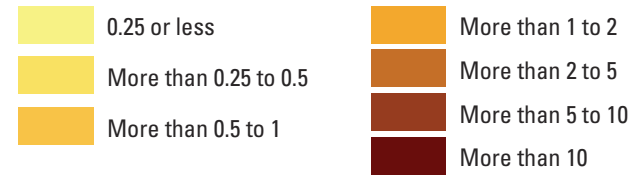

Figure 25. Decreases in simulated water-table altitudes between the late 20th century (1970-99) and the late 21st century (2070-99) for $A$, September and B, October for two greenhouse gas emission scenarios (B1, lower emissions and $A 2$, higher emissions) in the Chipuxet River and Chickasheen Brook Basins, Rhode Island. Projected values represent the averages of five global circulation models. 


\section{Limitations of Analysis}

The finite-difference numerical models of the Chipuxet River and Chickasheen Brook Basins are regional-scale simulations of groundwater flow, water levels, and the interaction between groundwater and surface water. Simplification included consolidating parameters that represented hydraulic properties and boundary conditions into homogenous units and assigning these parameters to groups of model grid cells sized $125 \mathrm{ft}$ by $125 \mathrm{ft}$. Groundwater flow in bedrock represented the bulk flow in the regional system instead of the flow through bedrock fractures. Thus the models account for the overall movement of groundwater through bedrock before it discharges to the valley-fill deposits. For these reasons, the models might not be appropriate for simulating localscale results, but the models are useful for evaluating aquifer vulnerability to contamination and climate change effects at a regional scale.

Spatial and temporal variability in recharge to surficial materials for the groundwater-flow models was calculated by using the SWB model, which uses climate and spatially distributed variables, such as soil type and land use at the same grid size as the groundwater-flow models. The SWB model, however, was calibrated to base flow at only one streamgage, whose groundwater contributing area was not accurately known, and to literature values for only undeveloped forested land cover. Neither the SWB model nor the groundwater-flow models represent unsaturated zone processes. SWB calculations of water that infiltrates below the root zone was assumed to immediately reach the water table as recharge in the groundwater flow simulations. In areas where the water table is close to the land surface, such as forested wetlands, recharge rates calculated by the SWB model would be expected to be rough estimates.

Uncertainty in the simulated areas contributing recharge to the production wells was based on the observation dataset and not from model design. Additional groundwater-level and base-flow observations and other types of field observations might help reduce the uncertainty about the extent of the simulated contributing area by increasing the precision of the parameter value estimates. Additional observations might also help to increase the number of parameters that could be estimated using nonlinear regression, thereby decreasing the need for using prior information from the literature. The resulting uncertainty analysis would then be based solely on objective model calibration data. Uncertainty in the simulated contributing areas assumed that most plausible values are included in the analysis. Also, the base-flow observations used in the calibration represented the net gain in base flow over relatively large segments of stream reaches upstream of the observation. To gain a better understanding of the interactions between groundwater and surface water and of the vertical hydraulic conductivity of the streambed near the pumping wells requires observations that represent a net gain or loss in base flow over shorter stream reaches near the wells.
The simulated groundwater traveltimes were based on the calibrated steady-state model and uniform porosity for each of the lithologic units. An uncertainty analysis of groundwater traveltimes based on the spatial variability and the plausible range in porosity was beyond the scope of this study. However, in a steady-state model, porosity does not affect the location or size of the simulated area that contributes recharge to a well. Traveltimes also do not take into account traveltime in the unsaturated zone between the land surface and the water table.

Predicting changes to the hydrologic system from climate change decades into the future have, of course, large uncertainties. To reduce the uncertainty in how climate might respond to greenhouse gases, five GCMs were used in the analysis. To address uncertainties in levels of greenhouse gas emissions in the future, scenarios based on a lower and a higher emission were used in the analysis that represent different projections of human development. The analysis of the effects of climate change on the groundwater system only took into account changes in recharge. Other factors that might affect water resources, such as changing vegetation and water usage caused by a changing climate, were not included in model simulations. Under or over predicting recharge for historical conditions might under or over predict changes in recharge for the climate change analysis. In addition, the calibration of the SWB and groundwater-flow models assumed that model inputs and processes for historical conditions will be applicable under future conditions. Finally, the transient groundwater-flow model simulated an average annual cycle of monthly hydrologic conditions representative of 30-year periods for the climate change analysis. Because the transient model was developed for long-term average monthly conditions, the effects of climate change on the groundwater system from short-term events, such as droughts and floods, cannot be evaluated.

\section{Summary and Conclusions}

The Chipuxet River and Chickasheen Brook Basins in southern Rhode Island are an important water resource for public and domestic supply, irrigation, recreation, and aquatic habitat. Large-capacity production wells supply village centers and a university campus. Irrigated lands include agriculture, primarily turf farming. The U.S. Geological Survey, in cooperation with the Rhode Island Department of Health, Office of Drinking Water Quality, began a 2-year study in 2012 as part of an effort to protect the source of water to six large-capacity production wells and to increase understanding of the effects of climate change on the groundwater system.

Three principal geologic units underlie the 24.4-squaremile $\left(\mathrm{mi}^{2}\right)$ study area - glacial stratified deposits, glacial till, and crystalline bedrock. Glacial deposits range from a few feet to more than 200 feet (ft) in thickness. Postglacial deposits of alluvium and wetland deposits locally overlie glacial deposits, 
including Great Swamp, one of the largest wetlands in New England. The stratified deposits are subdivided into coarsegrained units (sand and gravel; sand) and fine-grained units (very fine sand, silt, and clay). The large-capacity production wells are screened in the transmissive coarse-grained deposits.

Steady-state and transient numerical models were developed and calibrated to simulate groundwater flow in the surficial deposits and the underlying bedrock. The steadystate model simulates long-term mean annual hydrologic conditions, whereas the transient model represents an average annual cycle of monthly hydrologic stresses. The steady-state model was calibrated by inverse modeling using nonlinear regression. Eleven parameters representing hydraulic properties were evaluated for nonlinear regression: seven horizontal hydraulic conductivity parameters, three vertical anisotropy parameters, and one streambed hydraulic conductivity parameter. Four horizontal hydraulic conductivity parameters were estimated with nonlinear regression; the remaining parameters were specified on the basis of values reported in the literature (prior information) because observations ( 98 groundwater levels and 2 base flows) did not provide sufficient information on them. Estimated optimal values for parameters representing horizontal hydraulic conductivities were as follows: coarsegrained stratified deposits, 99.3 feet per day $(\mathrm{ft} / \mathrm{d})$ and $155 \mathrm{ft} / \mathrm{d}$; till deposits, $18 \mathrm{ft} / \mathrm{d}$; and morainal deposits (the most precisely estimated of the four parameters), $36.9 \mathrm{ft} / \mathrm{d}$. The transient model was manually calibrated to monthly groundwater levels and base flows at one site for each. The specific yield of the glacial deposits varied from 0.05 for till deposits to 0.18 for stratified and morainal deposits.

A parameter representing recharge rates to the surficial materials was not considered for nonlinear regression, but it was included in an uncertainty analysis of the predicted contributing area to the wells. A soil-water-balance model was used to calculate the spatial and temporal variation in recharge for the groundwater-flow models based on climate variables, soil type, land use, and other factors. Calculated mean annual recharge rates ranged spatially from 15 inches per year (in/yr) to more than 31 in/yr. Mean annual recharge rate averaged over the entire study area was $25.0 \mathrm{in} / \mathrm{yr}$ or 51 percent of mean annual precipitation. The largest component of water loss before recharge was evapotranspiration at 37 percent. Average monthly recharge rates over the entire study area ranged from 0.2 inch in July to 4.5 inches in March.

The water systems of the Kingston Water District and the University of Rhode Island each include three high-capacity production wells. Five wells are clustered adjacent to the Chipuxet River, and one well is adjacent to Genesee Brook, a tributary stream. Areas contributing recharge to the wells were simulated by use of the steady-state model for each well's average withdrawal rate from 2007 through 2011 (total rate of 583 gallons per minute (gal/min)) and of each well's maximum pumping capacity (total rate of $3,700 \mathrm{gal} / \mathrm{min}$ ). Most simulated areas contributing recharge for average and maximum pumping rates extend upgradient of the production wells to morainal and upland till deposits and groundwater and topographical divides. Some contributing areas include isolated areas remote from the well, including small areas the size of a model cell. At the maximum pumping rates, the shape and location of the contributing areas to an individual well are strongly affected by nearby pumping wells. For the average pumping rates, the size of the areas contributing recharge to the wells covered a total area of $0.63 \mathrm{mi}^{2}$, and for the maximum pumping rate, $2.55 \mathrm{mi}^{2}$. Land cover in the areas contributing recharge to the wells adjacent to the Chipuxet River includes a substantial amount of urban and agricultural land uses, but for the well near Genesee Brook, land use is less developed. Simulated groundwater traveltimes from recharge locations to production wells for the maximum pumping rates ranged from less than 1 year to more than 200 years. Median traveltimes ranged from 3.5 to 8.6 years, and traveltimes of 10 years or less ranged from 57 to 91 percent for the wells. These relatively short traveltimes indicate that the wells are vulnerable to contamination from activities on the land surface.

The calibrated groundwater-flow model provided a single, best representation of the area contributing recharge to the wells. Parameter uncertainty and its associated effects on the simulated areas contributing recharge to the wells were evaluated using a stochastic Monte Carlo analysis. This analysis was done so that the contributing areas to the wells would not be underestimated, thereby leaving the wells inadequately protected. This analysis led to contributing areas expressed as a probability distribution that differs from a single or deterministic contributing area. Optimal parameter values and the parameter variance-covariance matrix from nonlinear regression were used to create parameter sets for the analysis. The parameter variance-covariance matrix preserves the uncertainty of the parameter estimates and the correlation among parameters from the calibrated model. The remaining parameters representing surficial hydraulic properties and recharge rates that were not estimated with nonlinear regression were also incorporated into the parameter variance-covariance matrix. Because observations did not provide enough information to constrain the uncertainty of these parameters within realistic ranges around the specified values, prior information was required. The uncertainty analysis was an outcome of calibrating the model to available observations but also depended on information provided by the modeler. Three acceptance criteria were used to assess parameter sets so that prediction uncertainty was not overestimated: the model converged, model mass balance was 1 percent or less, and a model-fit statistic, the calculated error variance, was 90 or less, or five times the calibrated model value. Of 500 parameter sets using pumping values from the calibrated model, 467 fit the acceptance criteria. The 2007 through 2011 average pumping rates and the maximum pumping rates used these 467 parameter sets with the first two acceptance criteria.

The size of the probabilistic contributing areas for both average and maximum pumping rates was larger than the size of the deterministic contributing areas for the wells because of 
the effects of parameter uncertainty. Thus, some areas not in the deterministic contributing area, including additional areas with urban and agricultural land cover that have the potential to contaminate groundwater resources, might actually be in the contributing area. In most cases, areas with high probabilities (more than 40 percent) generally coincided with the deterministic contributing areas. Low probabilities are generally in areas distant from the pumping wells and in areas where simulated streams intercepted precipitation recharge in the deterministic model. Also, areas associated with low probabilities extended long distances along groundwater divides in the uplands remote from the wells for the maximum pumping rates.

Climate projections for the Chipuxet River and Chickasheen Brook Basins from downscaled output from five general circulation models driven by two emission scenarios were used to investigate how changes in climate in the 21 st century might affect the groundwater system. The two emission scenarios represent lower and higher emissions of greenhouse gases based on projections of human development. The lower and higher emission scenarios reach atmospheric carbon dioxide concentrations by 2100 about double and triple, respectively, preindustrial levels. Climate projections were used in the soil-water-balance model to evaluate potential changes to the water balance near the land surface. Recharge rates calculated by the soil-water-balance model were then used in the groundwater-flow models to quantify the hydrologic response to climate change. Other climate-change-related factors, such as changing land cover and water usage, that might affect the groundwater system were not included in model simulations. The effects of climate change were assessed by comparing three periods in the 21 st century (early century, 2010-39; midcentury, 2040-69; and late century, 2070-99) to an historical baseline period in the late 20th century (1970-99). Results of the climate change analysis might be applicable to aquifers of glacial origin in the northeastern United States where there is little snow accumulation during winter.

Projected increases in temperature by the mid-21st century are larger for the higher emission scenario compared with the lower emission scenario, annually and for all seasons. By the late 21st century, projected increases in mean annual temperature are 4.7 Fahrenheit $\left({ }^{\circ} \mathrm{F}\right)$ for the lower emissions scenario and $8.0^{\circ} \mathrm{F}$ for the higher emissions scenario compared with the late 20th century. Mean annual precipitation is also projected to increase in the 21 st century compared with the late 20th century for both emission scenarios; by the late 21 st century, both emission scenarios project an increase of about 8 percent. Seasonal precipitation changes, however, are expected to vary, with winter and spring increases being larger and summer increases being about the same, as mean annual precipitation changes. By the late 21 st century, fall precipitation is expected to decrease by 5 percent for both emission scenarios.

These projected changes in the magnitude and seasonal distribution of precipitation and in warming temperatures in the 21 st century affect the magnitude and timing of recharge compared with the late 20th century. Although precipitation is expected to increase in three seasons, only in winter do precipitation increases exceed actual evapotranspiration increases. Recharge is projected to decrease in fall and generally change little in spring and summer. By the late 21st century, winter recharge is expected to increase by 13 percent for the lower emissions scenario and by 15 percent for the higher emissions scenario. In fall, recharge diminishes by 13 percent and 24 percent for the lower and higher emissions scenarios. Although recharge is projected to change seasonally in the 21 st century, mean annual recharge changes minimally.

Soil moisture is projected to decrease in the $21 \mathrm{st}$ century from spring through fall because of increases in potential evapotranspiration, and in fall because of decrease in precipitation in addition to increases in potential evapotranspiration. By the late 21st century, soil moisture for the lower emissions scenario is expected to decrease by 11 percent in summer and 15 percent in fall and for the higher emissions scenario, decrease by 23 percent for both seasons. These decreases in soil moisture during the growing season might have implications for agriculture.

The effects of predicted changes in the seasonal distribution of recharge rates in the 21 st century on base flows were analyzed at two sites with different drainage area sizes and percentages of glacial deposit types. Two sites were the Chipuxet River, which drains a mix of glacial deposits, and a headwater stream, which drains thin till deposits one-tenth the basin size with shorter groundwater-flow paths and lower storage properties than the Chipuxet River Basin. Because of increased recharge in winter, base flows in the winter months increase by 5 to 10 percent through the 21 st century for both stream sites and both emission scenarios. Because of less recharge in fall and less or about the same recharge in the preceding months of spring and summer, base flow in the fall months decreases for both sites and both emission scenarios. Base flow in September, the month with the lowest flows, is lower in the 21st century than in the late 20th century; late 21 st century base flows at the Chipuxet River streamgage decrease by a few percentages for the lower emissions scenario and by 8 percent for the higher emissions scenario, and at the till site, decrease by 12 percent and 23 percent for the lower and higher emissions scenarios, respectively. October has the largest base flow decreases; by the late 21 st century, base flows at the Chipuxet River streamgage diminish by 9 percent for the lower emissions scenario and by 18 percent for the higher emissions scenario, and at the till site, decrease by 28 percent and 42 percent for the lower and higher emissions scenarios, respectively. These results indicate that projected changes in recharge might extend the low-flow period of the year later into fall and that there might be more intermittent headwater streams compared with the late 20th century, accompanied by corresponding implications to aquatic habitat.

Groundwater levels are also predicted to be higher in winter and lower in fall in the 21st century compared with the late 20th century because of the seasonal changes in recharge. 
The largest groundwater level changes are predicted to be in October and for the higher emission scenario and extend low water levels for the year later into fall. Groundwater level changes in the uplands show substantial decreases in fall, but in the valley, because of the large storage capacity of stratified deposits, water levels change minimally. The largest changes to water levels in the valley are generally distant to streams and near the valley edges. Groundwater levels in the upland till deposits by the late 21 st century in September decrease by up to $1 \mathrm{ft}$ in small areas for the lower emission scenario, and by up to $2 \mathrm{ft}$ in substantial areas of till for the higher emission scenario. In October, water levels in large areas of till decrease by up to $2 \mathrm{ft}$ for the lower emission scenario, whereas large areas decrease by up to $5 \mathrm{ft}$, with small areas with decreases of as much as $10 \mathrm{ft}$ for the higher emission scenario. For both emission scenarios, more areas of till go dry in fall in the 21 st century compared with the late 20 th century. Finally, the size and location of the simulated areas contributing recharge to the production wells are minimally affected by climate change because mean annual recharge changes little in the 21 st century.

\section{References Cited}

Allen, W.B., Hahn, G.W., and Brackley, R.A., 1966, Availability of ground water, upper Pawcatuck River Basin, Rhode Island: U.S. Geological Survey Water-Supply Paper 1821, 66 p., http://pubs.usgs.gov/wsp/1821/report.pdf.

Allen, W.B., Hahn, G.W., and Tuttle, C.R., 1963, Geohydrological data for the upper Pawcatuck River Basin, Rhode Island: Providence, R.I., Rhode Island Water Resources Coordinating Board Geological Bulletin 13, 68 p., 1 pl., scale 1:24,000.

Balco, Greg, Briner, Jason, Finkel, R.C., Rayburn, J.A., Ridge, J.C., and Schaefer, J.M., 2009, Regional beryllium-10 production rate calibration for late-glacial northeastern North America: Quaternary Geochronology, v. 4, no. 2, p. 93-107, http://dx.doi.org/10.1016/j.quageo.2008.09.001.

Barlow, P.M., and Dickerman, D.C., 2001, Numericalsimulation and conjunctive-management models of the Hunt-Annaquatucket-Pettaquamscutt stream-aquifer system, Rhode Island: U.S. Geological Survey Professional Paper 1636, 88 p., http://pubs.usgs.gov/pp/pp1636/.

Bent, G.C., 1995, Streamflow, ground-water recharge and discharge, and characteristics of surficial deposits in Buzzards Bay Basin, southeastern Massachusetts: U.S. Geological Survey Water-Resources Investigations Report 95-4234, 56 p., http://pubs.usgs.gov/wri/wri954234/.
Bent, G.C., 1999, Streamflow, base flow, and groundwater recharge in the Housatonic River Basin, western Massachusetts and parts of eastern New York and northwestern Connecticut: U.S. Geological Survey WaterResources Investigations Report 98-4232, 68 p., http://pubs.usgs.gov/wri/wri984232/.

Bent, G.C., Steeves, P.A., and Waite, A.M., 2014, Equations for estimating selected streamflow statistics in Rhode Island: U.S. Geological Survey Scientific Investigations Report 2014-5010, 65 p., http://pubs.usgs.gov/ sir/2014/5010/.

Bent, G.C., Zarriello, P.J., Granato, G.E., Masterson, J.P., Walter, D.A., Waite, A.M., and Church, P.E., 2011, Simulated effects of water withdrawals and land-use changes on streamflows and groundwater levels in the Pawcatuck River Basin, southwestern Rhode Island and southeastern Connecticut: U.S. Geological Survey Scientific Investigations Report 2009-5127, 254 p., http://pubs.usgs.gov/ sir/2009/5127/.

Bierschenk, W.H., 1956, Ground-water resources of the Kingston quadrangle, Rhode Island: Rhode Island Development Council Geological Bulletin 9, 60 p.

Bjerklie, D.M., Hay, L.E., and Markstrom, S.L., 2012, Watershed scale response to climate change-Pomperaug River watershed, Connecticut: U.S. Geological Survey Fact Sheet 2011-3122, 6 p., http://pubs.usgs.gov/fs/2011/3122/.

Bjerklie, D.M., Trombley, T.J., and Viger, R.J., 2011, Simulations of historical and future trends in snowfall and groundwater recharge for basins draining to Long Island Sound: Earth Interactions, v. 15, paper 34, 35 p., http://dx.doi.org/10.1175/2011EI374.1.

Boothroyd, J.C., Freedman, J.H., Brenner, H.B., and Stone, J.R., 1998, The glacial geology of southern Rhode Island, in Murray, D.P., ed., New England Intercollegiate Geological Conference, 90th annual meeting, Kingston, R.I., October 9-11, 1998, Guidebook for fieldtrips in Rhode Island and adjacent regions of Connecticut and Massachusetts: Kingston, R.I., University of Rhode Island, trip C5, p. C5.1-C5.25.

Boving, Thomas, Veeger, Anne, and Logan, Patricia, 2008, Enhancing drinking water supply by better understanding surface water-ground water interaction: Kingston, R.I., University of Rhode Island, 35 p., http://water.usgs.gov/ wrri/07grants/progress/2007RI68B.pdf.

Cronshey, Roger, McCuen, R.H., Miller, Norman, Rawls, Walter, Robbins, Sam, and Woodward, Don, 1986, Urban hydrology for small watersheds TR-55 (2d ed.): Washington, D.C., U.S. Department of Agriculture Soil Conservation Service Technical Release 55, [variously paginated], http://www.cpesc.org/reference/tr55.pdf. 
DeSimone, L.A., and Ostiguy, L.J., 1999, A vulnerability assessment of public-supply wells in Rhode Island: U.S. Geological Survey Water-Resources Investigations Report 99-4160, 153 p., http://pubs.usgs.gov/ wri/1999/4160/report.pdf.

Dickerman, D.C., 1976, Geohydrologic data for the Chipuxet River ground-water reservoir, Rhode Island: Rhode Island Water Resources Board Information Series Report 2, 86 p.

Dickerman, D.C., 1984, Aquifer tests in the stratified drift, Chipuxet River Basin, Rhode Island: U.S. Geological Survey Water-Resources Investigations Report 83-4231, 39 p., http://pubs.usgs.gov/wri/1983/4231/report.pdf.

Dickerman, D.C., and Barlow, P.M., 1997, Water-table conditions and stream-aquifer interaction in the HuntAnnaquatucket-Pettaquamscutt aquifer, central Rhode Island, October 7-9, 1996: U.S. Geological Survey WaterResources Investigations Report 97-4167, scale 1:24,000, 1 sh., http://pubs.usgs.gov/wri/1997/4167/plate-1.pdf.

Dickerman, D.C., Kliever, J.D., and Stone, J.R., 1997, Hydrogeology, water quality, and simulation of groundwater-development alternatives in the Usquepaug-Queen ground-water reservoir, southern Rhode Island: U.S. Geological Survey Water-Resources Investigations Report 97-4126, 48 p., 1 sheet, http://pubs.usgs.gov/ wri/1997/4126/report.pdf.

Dickerman, D.C., Trench, E.C.T., and Russell, J.P., 1990, Hydrogeology, water quality, and ground-water development alternatives in the lower Wood River ground-water reservoir, Rhode Island: U.S. Geological Survey WaterResources Investigations Report 89-4031, 109 p., http://pubs.usgs.gov/wri/1989/4031/report.pdf.

Dudley, R.W., Hay, L.E., Markstrom, S.L., and Hodgkins, G.A., 2012, Watershed scale response to climate change - Cathance Stream Basin, Maine: U.S. Geological Survey Fact Sheet 2011-3128, 6 p., http://pubs.usgs.gov/ $f_{S} / 2011 / 3128 /$.

Dudley, R.W., and Hodgkins, G.A., 2013, Historical groundwater trends in northern New England and relations with streamflow and climatic variables: Journal of the American Water Resources Association, v. 49, no. 5, p. 1198-1212, http://dx.doi.org/10.1111/jawr.12080.

Farnsworth, R.K., Thompson, E.S., and Peck, E.L., 1982, Evaporation atlas for the contiguous 48 United States: National Oceanic and Atmospheric Administration Technical Report NWS 33, 26 p., 4 pls., http://www.nws.noaa.gov/ oh/hdsc/Technical_reports/TR33.pdf.

Fenneman, N.M., 1938, Physiography of the eastern United States: New York, McGraw-Hill Book Company, 714 p.
Freeze, R.A., and Cherry, J.A., 1979, Groundwater: Englewood Cliffs, N.J., Prentice Hall, 604 p.

Friesz, P.J., 2004, Delineation of areas contributing recharge to selected public-supply wells in glacial valley-fill and wetland settings, Rhode Island: U.S. Geological Survey Scientific Investigations Report 2004-5070, 57 p., http://pubs.usgs.gov/sir/2004/5070/.

Friesz, P.J., 2010, Delineation and prediction uncertainty of areas contributing recharge to selected wells fields in wetland and coastal settings, southern Rhode Island: U.S. Geological Survey Scientific Investigations Report 2010-5060, 69 p., http://pubs.usgs.gov/sir/2010/5060/.

Friesz, P.J., 2012, Evaluating prediction uncertainty of areas contributing recharge to well fields of multiple water suppliers in the Hunt-Annaquatucket-Pettaquamscutt River Basins, Rhode Island: U.S. Geological Survey Scientific Investigations Report 2012-5114, 46 p., http://pubs.usgs.gov/sir/2012/5114/.

Friesz, P.J., and Stone, J.R., 2007, Simulation of ground-water flow and areas contributing recharge to production wells in contrasting glacial valley-fill settings, Rhode Island: U.S. Geological Survey Scientific Investigations Report 20075133, 50 p., http://pubs.usgs.gov/sir/2007/5133/.

Garabedian, S.P., LeBlanc, D.R., Gelhar, L.W., and Celia, M.A., 1991, Large-scale natural gradient tracer test in sand and gravel, Cape Cod, Massachusetts-2. Analysis of spatial moments for a nonreactive tracer: Water Resources Research, v. 27, no. 5, p. 911-924, http://dx.doi.org/10.1029/91WR00242.

Gburek, W.J., Folmar G.J., and Urban, J.B., 1999, Field data and ground-water modeling in a layered fractured aquifer: Ground Water, v. 37, no. 2, p. 175-184, http://dx.doi.org/10.1111/j.1745-6584.1999.tb00972.x.

Gonthier, J.B., Johnston, H.E., and Malmberg, G.T., 1974, Availability of ground water in the Lower Pawcatuck River Basin, Rhode Island: U.S. Geological Survey Water-Supply Paper 2033, 40 p., 4 pls, http://pubs.er.usgs.gov/publication/ wsp2033.

Hahn, G.W., 1959, Ground-water map of the Slocum quadrangle, Rhode Island: Rhode Island Water Resources Coordinating Board map GWM-2, 1 sheet, scale 1:24,000.

Harbaugh, A.W., 2005, MODFLOW-2005, the U.S. Geological Survey modular ground-water model-the ground-water flow process: U.S. Geological Survey Techniques and Methods, book 6, chap. A16, [variously paged], http://pubs.usgs.gov/tm/2005/tm6A16/. 
Hayhoe, Katharine, Stoner, A., Yang, X., Crow, C., Swaminathan, Scott-Fleming, I., Ryu, J., Gelca, R., and Swain, S., 2013, Final report-Development and dissemination of a high-resolution national climate change dataset, [variously paged], http://cida.usgs.gov/thredds/fileServer/dcp/files/ Hayhoe_USGS_downscaled_database_final_report.pdf.

Hayhoe, Katharine, Wake, C.P., Huntington, T.G., Luo, Lifeng, Schwartz, M.D., Shefield, Justin, Wood, Eric, Anderson, Bruce, Bradbury, James, DeGaetano, Art, Troy, T.J., and Wolfe, David, 2007, Past and future changes in climate and hydrological indicators in the US northeast:

Climate Dynamics, v. 28, no. 4, p. 381-407, http://dx.doi.org/10.1007/s00382-006-0187-8.

Hermes, O.D., Gromet, P.L., Murray, D.P., and Hamidzada, N.A., 1994, Bedrock geologic map of Rhode Island:

Kingston, R.I., University of Rhode Island, Rhode Island Map Series 1, scale 1:100,000.

Hill, M.C., and Tiedeman, C.R., 2007, Effective groundwater model calibration-With analysis of data, sensitivities, predictions, and uncertainty: New Jersey, John Wiley and Sons, Inc., 455 p.

Hodgkins, G.A., and Dudley, R.W., 2006, Changes in the timing of winter-spring streamflows in eastern North America, 1913-2002: Geophysical Research Letters, v. 33, no. 6, L06402, 5 p., http://dx.doi.org/10.1029/2005GL025593.

Huntington, T.G., Hodgins, G.A., Keim, B.D., and Dudley, R.W., 2004, Changes in the proportion of precipitation occurring as snow in New England (1949 to 2000): Journal of Climate, v. 17, no. 13, p. 2626-2636, http://dx.doi.org/10.1175/1520-0442(2004)017<2626:CITP $O P>2.0 . C O ; 2$.

Johnston, H.E., and Dickerman, D.C., 1985, Hydrology, water quality, and ground-water development alternatives in the Chipuxet ground-water reservoir, Rhode Island: U.S. Geological Survey Water-Resources Investigation Report 84-4254, 100 p., http://pubs.er.usgs.gov/publication/ wri844254.

Joubert, Lorraine, Hickey, Patricia, and Lucht, James, 2003, South Kingstown source water assessment: Kingston, R.I, University of Rhode Island Technical Report 03-07, 89 p., http://www.uri.edu/ce/wq/RESOURCES/dwater/ Assessments/PDFs/sk_report.pdf.

Kaye, C.A., 1960, Surficial geology of the Kingston quadrangle, Rhode Island, in Contributions to general geology: U.S. Geological Survey Geological Bulletin 1071-I, p. 341-396, 3 pls., http://pubs.usgs.gov/bul/1071i/.
Kingston Water District, 2013, Annual drinking water quality report for 2012: West Kingston, R.I., Kingston Water District, accessed March 4, 2014, at http://www.kingstonwaterdistrict.com/KWDCCR2013.pdf. [Report removed from Web site at time of publication].

Koteff, Carl, and Pessl, Fred, Jr., 1981, Systematic ice retreat in New England: U.S. Geological Survey Professional Paper 1179, 20 p., http://pubs.usgs.gov/pp/1179/report.pdf.

Lohman, S.W., 1979, Ground-water hydraulics: U.S. Geological Survey Professional Paper 708, 70 p., http://pubs.er.usgs.gov/publication/pp708/.

Lyford, F.P., Carlson, C.S., and Hansen, B.P., 2003, Delineation of water sources for public-supply wells in three fractured-bedrock aquifer systems in Massachusetts: U.S. Geological Survey Water-Resources Investigation Report 02-4290, 113 p., http://pubs.usgs.gov/wri/wri024290/.

Mack, T.J., 2009, Assessment of ground-water resources in the seacoast region of New Hampshire: U.S. Geological Survey Scientific Investigations Report 2008-5222, 188 p., http://pubs.usgs.gov/sir/2008/5222/.

Masterson, J.P., 2011, Simulated effects of withdrawals on groundwater flow (MODFLOW models), part 3 of Bent, G.C., Zarriello, P.J., Granato, G.E., Masterson, J.P., Walter, D.A., Waite, A.M., and Church, P.E., Simulated effects of water withdrawals and land-use changes on streamflows and groundwater levels in the Pawcatuck River Basin, southwestern Rhode Island and southeastern Connecticut: U.S. Geological Survey Scientific Investigations Report 20095127, p. 65-84, http://pubs.usgs.gov/sir/2009/5127/.

Masterson, J.P., Sorenson, J.R., Stone, J.R., Moran, S.B., and Hougham, Andrea, 2007, Hydrogeology and simulated ground-water flow in the Salt Pond region of southern Rhode Island: U.S. Geological Survey Scientific Investigations Report 2006-5271, 56 p., http://pubs.usgs.gov/ sir/2006/5271/.

Maurer, E.P., Wood, A.W., Adam, D.P., Letenmaier, D.P., and Nijssen, B., 2002, A long-term hydrologically-based data set of land surface fluxes and states for the conterminous United States: Journal of Climate, v. 15, p. 3237-3251, http://dx.doi.org/10.1175/1520-0442(2002)015<3237:ALTH $B D>2.0 . C O ; 2$.

Meinzer, O.E., 1923, The occurrence of ground water in the United States, with a discussion of principles: U.S. Geological Survey Water-Supply Paper 489, 321 p., http://pubs.usgs.gov/wsp/0489/report.pdf.

Melvin, R.L., de Lima, Virginia, and Stone, B.D., 1992, The stratigraphy and hydraulic properties of tills in southern New England: U.S. Geological Survey Open-File Report 91-481, 53 p., http://pubs.usgs.gov/of/1991/0481/report.pdf. 
Melvin, R.L., Stone, B.D., Stone, J.R., and Trask, N.J., 1992, Hydrogeology of thick till deposits in Connecticut: U.S. Geological Survey Open-File Report 92-43, 43 p., http://pubs.usgs.gov/of/1992/0043/report.pdf. [Reprinted as part of Connecticut Department of Environmental Protection Bulletin 20.]

Moench, A.F., Garabedian, S.P., and LeBlanc, D.R., 2000, Estimation of hydraulic parameters from an unconfined aquifer test conducted in a glacial outwash deposit, Cape Cod, Massachusetts: U.S. Geological Survey Open-File Report 00-485, 139 p., http://pubs.usgs.gov/pp/pp1629/.

Moore, G.E., Jr., 1964, Bedrock geology of the Kingston quadrangle, Rhode Island: U.S. Geological Survey Geological Bulletin 1158-E, p. E1-E21, 1 pl., scale 1:24,000, http://pubs.usgs.gov/bul/1158e/.

Nakićenović, Nebojša, Alcamo, Joseph, Davis, Gerald, de Vries, Bert, Fenhann, Joergen, Gaffin, Stuart, Gregory, Kenneth, Grübler, Arnulf, Jung, T.Y., Kram, Tom, La Rovere, E.L., Michaelis, Laurie, Mori, Shunsuke, Morita, Tsuneyuki, Pepper, William, Pitcher, Hugh, Price, Lynn, Riahi, Keywan, Roehrl, Alexander, Rogner, H.H., Sankovski, Alexei, Schlesinger, Michael, Shukla, Priyararshi, Smith, Steven, Swart, Robert, van Rooijen, Sascha, Victor, Nadejda, and Zhou Dadi, 2000, Special report on emissions scenarios; A special report of Working Group III of the Intergovernmental Panel on Climate Change: Cambridge, United Kingdom, Cambridge University Press, 599 p., http://www.grida.no/publications/ other/ipcc\% $\%$ Fsr/?src=/climate/ipcc/emission/index.htm.

Niswonger, R.G., Panday, Sorab, and Ibaraki, Motomu, 2011, MODFLOW-NWT, a Newton formulation for MODFLOW-2005: U.S. Geological Survey Techniques and Methods, book 6, chap. A37, 44 p., http://pubs.usgs.gov/tm/ tm6a37/.

Niswonger, R.G., and Prudic, D.E., 2005, Documentation of the streamflow-routing (SFR2) package to include unsaturated flow beneath streams-A modification to SFR1: U.S. Geological Survey Techniques and Methods, book 6, chap. A13, 50 p., http://pubs.usgs.gov/tm/2006/tm6A13/.

Poeter, E.P., Hill, M.C., Banta, E.R., Mehl, Steffen, and Christensen, Steen, 2005, UCODE 2005 and six other computer codes for universal sensitivity analysis, calibration, and uncertainty evaluation: U.S. Geological Survey Techniques and Methods, book 6, chap. A11, 283 p., http://pubs.usgs.gov/tm/2006/tm6a11/.

Pollock, D.W., 1994, User's guide for MODPATH/ MODPATH_PLOT, version 3-A particle tracking postprocessing package for MODFLOW, the U.S. Geological Survey finite-difference ground-water flow model: U.S. Geological Survey Open-File Report 94-464, [variously paginated], http://pubs.usgs.gov/of/1994/0464/report.pdf.
Power, W.R., Jr., 1957, Surficial geology of the Slocum quadrangle, Rhode Island: U.S. Geological Survey Geologic Quadrangle GQ-106, 1 sh., scale 1:31,680, http://pubs.er.usgs.gov/publication/gq106/.

Power, W.R., Jr., 1959, Bedrock geology of the Slocum quadrangle, Rhode Island: U.S. Geological Survey Geologic Quadrangle GQ-114, 1 sh., scale 1:31,680, http://pubs.er.usgs.gov/publication/gq114/.

Randall, A.D., Thomas, M.P., Thomas, C.E., Jr., and Baker, J.A., 1966, Water resources inventory of Connecticut; part 1, Quinebaug River Basin: Connecticut Water Resources Bulletin 8, 102 p., http://pubs.usgs.gov/ ctwrb/0008/report.pdf.

Rhode Island Geographic Information System, 2007, Land cover/land use for Rhode Island 2003/04: State of Rhode Island Department of Administration, accessed August 12, 2014, at http://www.edc.uri.edu/rigis/datal data.aspx? ISO=planningCadastre.

Rhode Island Geographic Information System, 2011, Spring 2011 Rhode Island statewide lidar data-Provisional release: Kingston, R.I., University of Rhode Island, accessed December 7, 2012, at http://www.edc.uri.edu/rigis/ data/download/lidar/2011USGS/.

Rosenshein, J.S., Gonthier, J.B., and Allen, W.B., 1968, Hydrologic characteristics and sustained yield of principal ground-water units, Potowomut-Wickford area, Rhode Island: U.S. Geological Survey Water-Supply Paper 1775, 38 p., 5 pls., http:/pubs.er.usgs.gov/publication/wsp1775/.

Rutledge, A.T., 1998, Computer programs for describing the recession of ground-water discharge and for estimating mean ground-water recharge and discharge from streamflow records-Update: U.S. Geological Survey Water-Resources Investigations Report 98-4148, 43 p., http://pubs.usgs.gov/ wri/wri984148/pdf/wri98-4148.pdf.

Sanford, W.E., and Selnick, D.L., 2013, Estimation of evapotranspiration across the conterminous United States using a regression with climate and land-cover data: Journal of the American Water Resources Association, v 49, p. 217-230, http://dx.doi.org/10.1111/jawr.12010.

Schafer, J.P., 1961, Surficial geology of the Wickford quadrangle, Rhode Island, U.S. Geological Survey Quadrangle Map GQ-136, scale 1:24,000, http://pubs.er.usgs.gov/ publication/gq136/.

Starn, J.J., and Bagtzoglou, A.C., 2012, Programs for calibration-based Monte Carlo simulation of recharge areas: Ground Water, v. 50, no. 3, p. 472-476, http://dx.doi.org/10.1111/j.1745-6584.2011.00868.x. 
Starn, J.J., Bagtzoglou, A.C., and Robbins, G.A., 2010, Using atmospheric tracers to reduce uncertainty in groundwater recharge areas: Ground Water, v. 48, no. 6, p. 858-868, http://dx.doi.org/10.1111/j.1745-6584.2010.00674.x.

Stone, B.D., and Borns, H.W., Jr., 1986, Pleistocene glacial and interglacial stratigraphy of New England, Long Island, and adjacent Georges Bank and Gulf of Maine, in Sibrava, Vladimir, Bowen, D.Q., and Richmond, G.M., eds., Quaternary glaciations in the northern hemisphere: Quaternary Science Reviews, v. 5, p. 39-52, http://dx.doi.org/10.1016/0277-3791(86)90172-1.

Stone, J.R., Schafer, J.P., London, E.H., Lewis, R.L., DiGiacomo-Cohen, M.L., and Thompson, W.B., 2005, Quaternary geologic map of Connecticut and Long Island Sound Basin, with a section on Sedimentary facies and morphosequences of glacial meltwater deposits, by B.D. Stone and J.R. Stone: U.S. Geological Survey Scientific Investigations Map 2784, scale 1:125,000, 2 pls., 72-p. pamphlet

Stoner, A.M.K., Hayhoe, Katharine, Yang, Xiaohui, and Wuebbles, D.J., 2013, An asynchronous regional regression model for statistical downscaling of daily climate variables: International Journal of Climatology, v. 33, no. 11, p. $2473-$ 2494, http://dx.doi.org/10.1002/joc.3603.

Tetra Tech, Inc., 2012, Phase 2 report-Assessment of impacts, in Safe water Rhode Island: Providence, R.I., Rhode Island Department of Health, 64 p., http://www. health.ri.gov/materialbyothers/SafeWaterRIReport.pdf.

Thornthwaite, C.W., and Mather, J.R., 1957, Instructions and tables for computing potential evapotranspiration and the water balance: Centerton, N.J., Laboratory of Climatology, Publications in Climatology, v. 10, no. 3, p. 185-311.

Tiedeman, C.R., Goode, D.J., and Hsieh, P.A., 1997, Numerical simulation of ground-water flow through glacial deposits and crystalline bedrock in the Mirror Lake area, Grafton County, New Hampshire: U.S. Geological Survey Professional Paper 1572, 50 p., http://pubs.usgs.gov/pp/1572/ report.pdf.
Verry, E.S., and Boelter, D.H., 1979, Peatland hydrology, in Greeson, P.E., Clark, J.R., and Clark, J.E., eds., Wetland functions and values-The state of our understanding: Proceedings of the National Symposium on Wetlands, Lake Buena Vista, Fla., 1978, Minneapolis, Minn., American Water Resources Association, p. 389-402.

Waibel, M.S., Gannett, M.W., Chang, H., and Hulbe, C.L., 2013, Spatial variability of the response to climate change in regional groundwater systems-Examples from simulations in the Deschutes Basin, Oregon: Journal of Hydrology, v. 486, p. 187-201, http://dx.doi.org/10.1016/ j.jhydrol.2013.01.019.

Wake, C.P., Burakowski, Elizabeth, Kelsey, Eric, Hayhoe, Katharine, Stoner, Anne, Watson, Chris, and Douglas, Ellen, 2011, Climate change in the Piscataqua/Great Bay regionPast, present, and future: Durham, N.H., University of New Hampshire, 48 p., https://climatesolutionsne.org/sites/ climatesolutionsne.org/files/greatbayreport_online.pdf.

Wentworth, C.K., 1922, A scale of grade and class terms for clastic sediments: The Journal of Geology, v. 30, no. 5, p. 377-392, http://www.jstor.org/stable/30063207.

Westenbroek, S.M., Kelson, V.A., Dripps, W.R., Hunt, R.J., and Bradbury, K.R., 2010, SWB-A modified Thornthwaite-Mather soilwater-balance code for estimating groundwater recharge: U.S. Geological Survey Techniques and Methods, book 6, chap. A31, 60 p., http://pubs.usgs.gov/tm/ tm6-a31/.

Wild, E.C., and Nimiroski, M.T., 2004, Estimated water use and availability in the Pawcatuck Basin, southern Rhode Island and southeastern Connecticut, 1995-99: U.S. Geological Survey Scientific Investigations Report 2004-5020, 72 p., http://pubs.usgs.gov/sir/2004/5020/. 
Prepared by the Pembroke Publishing Service Center.

For more information concerning this report, contact

Office Chief

Massachusetts-Rhode Island Office

New England Water Science Center

U.S. Geological Survey

10 Bearfoot Road

Northborough, MA 01532

dc_ma@usgs.gov

or visit our Web site at

http://ma.water.usgs.gov 


\section{$\frac{\mathbb{3}}{\mathrm{C}}$}

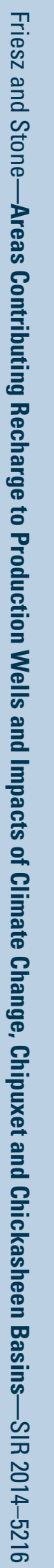

